\title{
RELACION ESTRUCTURA-
}

\section{FUNCION PATOGENICIDAD DE LA}

\section{APOLIPOPROTEÍNA A-I HUMANA}

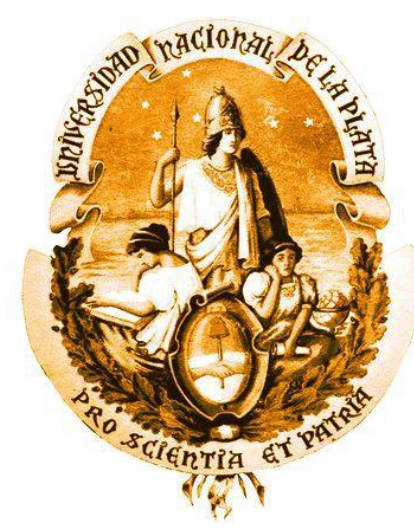

\section{TESIS DOCTORAL UNIVERSIDAD NACIONAL DE LA PLATA}

FACULTAD DE CIENCIAS MÉDICAS -2017-

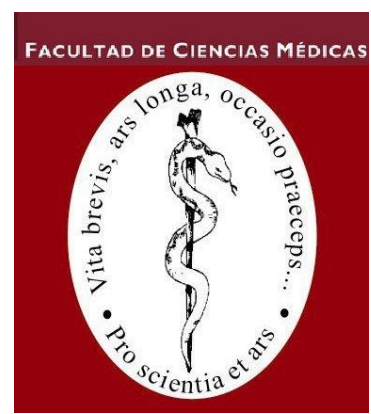

TESISTA: MÉD ROSU, SILVANA ANTONIA DIRECTOR: DRA TRICERRI, M. ALEJANDRA CO-DIRECTOR: DR RIMOLDI, OMAR J. 
El presente trabajo de tesis, para optar al grado de Doctora de la Facultad de Ciencias Médicas de la Universidad Nacional de La Plata, fue realizado en el Instituto de Investigaciones Bioquímicas de La Plata (INIBIOLP), Facultad de Ciencias Médicas, Universidad Nacional de La Plata, bajo la dirección de la Dra. M. Alejandra Tricerri y la co-dirección del Dr. Omar J. Rimoldi. 


\section{$\underline{\text { Resumen }}$}

Una serie de mutaciones naturales de la apolipoproteína A-I humana (apoA-I) se han asociado con amiloidosis hereditaria. Los mecanismos moleculares implicados en la patología asociada a amiloide siguen siendo en gran parte desconocidos. Aquí se examinaron los efectos de la mutación Arg173-Pro en apoA-I, una variante asociada a amiloidosis cardíaca, laríngea y cutánea principalmente, sobre la estructura, estabilidad, propensión a la agregación, interacción con ligandos putativos, y su capacidad para desencadenar una respuesta proinflamatoria.

En los ensayos realizados y que se describen a lo largo de este trabajo evidenciamos que tal variante tiene una menor estabilidad intrínseca, incluso con pérdida de su estructura secundaria (35\% menos según los ensayos de dicroísmo circular), una mayor propensión a la agregación en condiciones fisiológicas. La variante, además mostró una mayor unión a Heparina a pH fisiológico, estos complejos fueron visualizados en geles de poliacrilamida y por AFM.

Como modelo tridimensional sintético de matriz extracelular, se nos presentó la posibilidad de formar polímeros de dos componentes que exponen grupos similares a los expuestos en GAGs (hidroxilos y sulfatos). En estos polímeros, la variante natural se asoció principalmente a las matrices con mayor grado de sulfatación, evidenciando una interacción específica de grupo con estos ligandos.

Por último, la variante indujo una mayor liberación de Il-1ß Y TNF- $\alpha$ por parte de monocitos THP, evidenciando así una capacidad para desencadenar potencialmente una respuesta pro-inflamatoria. Además mostró una mayor susceptibilidad al clivaje proteolítico de proteasas como metaloproteasa 12 y Tripsina, lo cual no sabemos todavía, pero los fragmentos generados podrían o no contribuir mayormente al desarrollo y perpetuación de esta patología.

Todo lo estudiado nos aportó muchísimo conocimiento y comprensión sobre el comportamiento de las variantes en la fisiopatogenia de la amiloidosis, pero además nos tendió caminos para analizar y profundizar acerca de los diversos mecanismos implicados.

Finalmente un campo vacante en la Argentina es el diagnóstico de amiloidosis debida a apo A-I. Si bien nuestro grupo tiene escasa experiencia en el diagnostico clínico uno de los objetivos a futuro es el diagnostico por inmunohistoquímica y secuenciación génica, afín de contribuir no sólo a la epidemiología sino también el impacto de esta enfermedad en La Plata y sus alrededores. 
Dedico este trabajo a: Mi MAMÁ, María Esther Fernández, por haberme acompañado estos 31 años y dejarme los mejores recuerdos A mi Papá y mis hermanos, por estar siempre a mi lado.

A Damián, mi amor, por su incondicionalidad. 
De los miedos nacen los corajes; y de las dudas las certezas. Los sueños anuncian otra realidad posible y los delirios otra razón.

Al fin y al cabo, somos lo que hacemos para cambiar lo que somos. La identidad no es una pieza de museo, quietecita en la vitrina, sino la siempre asombrosa síntesis de las contradicciones nuestras de cada día

Eduardo Galeano.

El libro de los Abrazos 


\section{$\underline{\text { Agradecimientos }}$}

A mi directora de tesis, la Dra. Maria Alejandra Tricerri, por confiar en mí para realizar este trabajo, por haberme acompañado, estar dispuesta a ayudarme y aconsejarme en todo momento, por no dejarme caer ante mis adversidades y seguir adelante con fuerza y optimismo; Una persona excepcional, quién se transformó en mi ideal a seguir tanto laboralmente como humanamente.

A mi co-director, el Dr. Omar J. Rimoldi, de quién lamento muchísimo su partida, y no voy a olvidar su dedicación conmigo en los primeros años del doctorado, sus metódicas enseñanzas y su constancia para obtener los resultados deseados (que nos costaron como un año y todos recordarán como estaba).

Al Director del INIBIOLP, Dr. Horacio Garda, por permitirme realizar este trabajo en el instituto.

A la Universidad Nacional de La Plata y CONICET por financiar mi doctorado.

Al grupo de trabajo: Gabriela, Nahuel, Gisela, Tati y Guille por hacer amenas las horas de trabajo, donde compartimos charlas, mates, alegrías, tristezas, aparte del arduo trabajo, no? Todo eso fue formando un cálido ambiente de amistad donde me he sentido casi como en mi hogar.

A todos los integrantes del INIBIOLP, ya que todos de una u otra manera me acompañaron en este trayecto y, no sólo eso, sino que me ayudaron a superar uno de los momentos más difíciles de mi vida, acompañándome y aconsejándome. Les agradezco de corazón por eso. No puedo dejar de mencionar a los más allegados: Ivo, Yani, Pili, Elizabeth, Yoselí, Marianela, Aldi, Agustina por estar siempre dispuestos a darme una mano.

A todo el Grupo de la Parroquia Stella Maris de Punta Lara, mis grandes amigos, que de la mano de Dios y la Virgen me acompañan siempre. Les agradezco permitirme formar parte de esa hermosa comunidad, crecer como persona y colmarme de buenos consejos e infinitas enseñanzas. No me bastan estas pocas líneas para decir todo, pero cada uno sabe lo mucho que lo aprecio. Sé además que están esperando este momento para llamarme Doctora, ya que no se los permito todavía. Al Padre Carlos Gómez por acompañarme. 
A Dai, Andre y Fabi por ser incondicionales; A Fredy, mi gran amigo, que ya no está y su familia que son muy importantes para mí. Al resto de mis amigos, de los cuales tengo los mejores recuerdos.

A mi fiel amiga del secundario, Eli, por vernos cada muerte de Obispo, pero cuando nos encontramos parece que no hubieran pasado los años. A mis compas de la facu, ya hoy colegas, por hacer amenos los muchos años de carrera, y hoy compartir nuestras distintas vivencias; A Mili, mi madrina, por todo lo vivido.

A mis compadres, Guada y Martín por permitirme disfrutar de mis ahijados (Zaid y Sofía) día a día y por ser dos personas excepcionales.

A Damián, por empujarme cada día, compartir todos los momentos, aguantar mis locuras y luchar a la par, construyendo poco a poco nuestro andar.

A mi familia: Mi mamá, que aún la extraño horrores, pero sé lo orgullosa que estaría hoy, luego de luchar día a día por verme crecer; nunca olvidaré su gran labor, siempre con humildad y sencillez; Mi papá, por esforzarse en darme lo mejor; Mis hermanos, Chu y Ale, por ser mis motores y estar siempre a mi lado. Mis hermanas Vane y Vani y mi sobrino Nico por disfrutar cada momento juntos. A mis cuñadas, Lu y Bere, por ser grandes compañeras.

A mis tíos y primos que los adoro con el alma gracias por alentarme cada día, creer y confiar en mí. En especial a mi padrino y tío Rubén por estar pendiente de mí y alentarme a seguir creciendo. 


\section{INDICE}

1. INTRODUCCIÓN

Pág 13

A. Apolipoproteína A-I (apoA-I). Estructura

Pág 13

B. Apolipoproteína A-I. Función Normal

Pág 15

C. Amiloidosis y Apolipoproteína A-I

Pág 18

D. Apolipoproteína A-I y Amiloidosis

Pág 18

E. Microambiente y conformación proteica

Pág 21

F. Aterosclerosis y amiloidosis

Pág 24

2. HIPÓTESIS DE TRABAJO

Pág 26

3. OBJETIVO GENERAL

Pág 27

Objetivos específicos

Pág 27

4. MATERIALES Y MÉTODOS

Pág 28

A. Obtención de apoA-I Wild type, Wt o mutada (Arg173Pro)

Pág 28

mediante la expresión a partir de cultivos bacterianos.

I. Obtención y amplificación de vectores para clonación: plásmidos. Pág 28

II. Tratamiento de bacterias para conferirles competencia

Pág 30

III. Transformación

Pág 30

IV. Construcción del mutante de apoA-I

Pág 31

V. Expresión y purificación

Pág 33

VI. Conservación de las proteínas y cuantificación Pág 35

B. Técnicas electroforéticas

Pág 35

I. Geles de agarosa

Pág 36

II. Geles de Poliacrilamida

Pág 36

C. Western Blot

Pág 38

I. Obtención de anticuerpos primarios anti apoA-I Pág 39

II. Purificación del anticuerpo en columnas Hi-Trap Pág 40

D. Técnicas de fluorescencia

Pág 41

I. Fundamentos de la técnica

Pág 41

II. Desnaturalización química de la proteína mediada por Gnd-HCl

Pág 43

III. Apagado (Quenching) con acrilamida $\quad$ Pág 44

IV. Dicroísmo circular (CD)

Pág 45

V. Titulación con Bis-ANS.

Pág 45

VI. Transferencia de energía de resonancia $\quad$ Pág 47 de fluorescencia de Trp a Bis-ANS

E. Detección de agregados de proteínas

Pág 47

F. Ensayo de aclaramiento de di miristoil fosfatidil colina (DMPC Pág 48

G. La unión de ligandos a apoA-I variantes $\quad$ Pág 48

H. Técnicas microscópicas $\quad$ Pág 49

AFM

Pág 49

I. Interacción de apoA-I con Polímeros sintéticos Pág 52

I. Construcción de polímeros.

Pág 52

II. Marcación de apoA-I con sondas de fluorescencia Pág 53

III. Interacción apoA-I con matrices

Pág 53 
- A través de ensayos de fluorescencia

Pág 53

- A través de microscopia confocal

Pág 54

IV. Interacción de proteínas con monómeros de la matriz

Pág 54

J. PROCESAMIENTO PROTEOLÍTICO DE VARIANTES DE apo A-I. Pág 55

K. ACTIVACIÓN DE MACRÓFAGOS HUMANOS

Pág 55

5. RESULTADOS

Pág 57

A. Estabilidad y conformación proteica

Pág 57

B. Propiedades de unión de lípidos de las variantes libres de lípidos

Pág 60

C. Formación de agregados tipo amiloide

Pág 61

D. Efecto del pH sobre la estructura de la proteína, la estabilidad

Pág 65

y la propensión a la agregación

E. Unión de ligandos

I. Interacción con dodecil sulfato de sodio (SDS)

Pág 69

II. Interacción con Heparina

Pág 69

Pág 72

F. Procesamiento proteolítico

Pág 74

G. Activación de macrófagos humanos

Pág 76

H. Ensayos con Polímeros sintéticos como modelo de matriz

Pág 77

I. Interacción apoA-I con matrices

- A través de ensayos de fluorescencia

Pág 78

Pág 78

- A través de microscopia confocal

II. Interacción de proteínas con monómeros de la matriz

Pág 79

Pág 80

6. DISCUSIÓN

Pág 83

A. Estabilidad, conformación proteica y tendencia a la agregación

Pág 83

B. Efecto del $\mathrm{pH}$ sobre la estructura de la proteína,

Pág 86

la estabilidad y la propensión a la agregación

C. Propiedades de unión a lípidos de las variantes

Pág 86

D. Procesamiento proteolítico

Pág 87

E. Las lecciones aprendidas de la unión de ligandos

Pág 88

I. $\underline{\text { SDS }}$

Pág 88

II. Glucosaminoglucanos

Pág 89

F. POLIMEROS

Pág 92

7. CONCLUSIONES GENERALES

Pág 95

8. BIBLIOGRAFIA

Pág 97 


\section{ABREVIATURAS}

ABCA-1

AFM

apoA-I

Bis-ANS

CE

$\mathrm{CINa}$

$\mathrm{CMC}$

DMPC

DNA

$\mathrm{DNCl}$

ECV

EGF

eNOS

FITC

GAGs

Gnd-HCl

HDL

HEMA

HUVEC

ICAM-1

IL-1

IPTG

LCAT

$\mathrm{LDL}_{\mathrm{ox}}$

MLV

MMP-12

$\mathrm{Mm}$

ndHDL

ON

PAGE

PCR

PVDF

ROS

SDS

$\mathrm{SSNa}$

TCR

TEM transportador de esteroles de membrana plasmática celular

Microscopio de fuerza atómica

Apolipoproteína A-I

Ácido 4,4'-Dianilino-1,1'-Binaftil-5,5'-

Disulfonico

Ésteres de colesterol

Cloruro de Sodio

Concentración micelar crítica

Di- miristoil fosfatidil colina

Ácido Desoxido ribonucleico

Cloruro de dansilo

Enfermedad cardiovascular

Factor de crecimiento endotelial

Óxido nítrico sintetasa endotelial

Isotiocianato de fluoresceína

Glicosaminoglicanos

Cloruro de Guanidilo

Lipoproteínas de alta densidad

metacrilato de 2-hidroxietilo

Células endoteliales de cordón

umbilical humano

Moléculas de adhesión intercelulares

Interleuquina 1

Isopropil tio galactósido

Lecitina colesterol acil transferasa

Lipoproteínas de baja densidad

oxidadas

Liposomas multilamelares

Metaloproteasa de matriz 12

mili Molar

Lipoproteínas de alta densidad

nacientes discoidales

Over night (toda la noche)

Electroforesis en gel de poliacrilamida

Reacción en cadena de la polimerasa

Polivinildifluoruro

Especies reactivas de oxígeno

Dodecil Sulfato Sódico

4-estirenosulfonato de sodio

Transporte reverso de colesterol

Microscopio electrónico de trasmisión 
TEMED

ThT

TNF- $\alpha$

TRC

Tris

TTR

UVL

VCAM-1 tetrametilenamida

Tioflavina - T

Factor de necrosis tumoral alpha Transporte reverso de colesterol

Tris (Hidroximetil) aminometano Transtiretina

zona del ultravioleta lejano

Moléculas de adhesión vascular 


\section{EL PRESENTE TRABAJO HA SIDO PUBLICADO EN:}

- Rosu SA, Rimoldi OJ, Prieto ED, Curto LM, Delfino JM, Ramella NA and Tricerri MA (2015) Amyloidogenic propensity of a natural variant of human apolipoprotein AI: stability and interaction with ligands. PLoS One 10, e0124946.

- Silvana A Rosú; Leandro Toledo; Bruno F Urbano; Susana A. Sanchez; M. Alejandra Tricerri. Learning from synthetic models: Differential binding of apolipoprotein $A-I$ to components of the extracellular matrix. Protein Journal. JOPC-D-17-00039. (Enviado a publicar) 


\section{INTRODUCCIÓN}

\section{A. APOLIPOPROTEINA A-I. ESTRUCTURA}

La Apolipoproteína humana A-I (apoA-I) es el principal componente proteico de las lipoproteínas de alta densidad (HDLs). Su peso molecular es de aproximadamente $28 \mathrm{kDa}$ y su estructura consiste en una secuencia de 243 aminoácidos codificados por el exón 3 (residuos de 1 al 43) y exón 4 (residuos 44-243) de un gen localizado en el brazo largo del cromosoma 11. Su síntesis sobre los ribosomas comienza con un prepropéptido de 24 aminoácidos codificados en el exón $1^{1}$; luego del clivaje del péptido señal de 18 aminoácidos, el pro-péptido es secretado al plasma, donde 6 aminoácidos son removidos por una metaloproteasa no identificada ${ }^{2}$. La remoción del propéptido es tan efectiva que menos del $5 \%$ de la apoA-I plasmática es representada por la pro-forma. La estructura secundaria de la apoA-I está representada por $\alpha$-hélices anfipáticas interrumpidas periódicamente por prolinas en la mayoría de los casos. Las $\alpha$-hélices son clasificadas en diferentes clases en base a la distribución de residuos cargados alrededor del eje de la hélice (figura 1.1)

- Clase A: caracterizadas por la presencia de residuos básicos cerca de la interfase hidrofóbica/hidrofílica y residuos ácidos en el centro de la cara polar.

- Clase G: Con una distribución aleatoria de residuos positivos y negativos sobre la cara polar.

- Clase Y: Con 3 grupos de residuos básicos en la cara polar, generando así un patrón en forma de letra "Y".

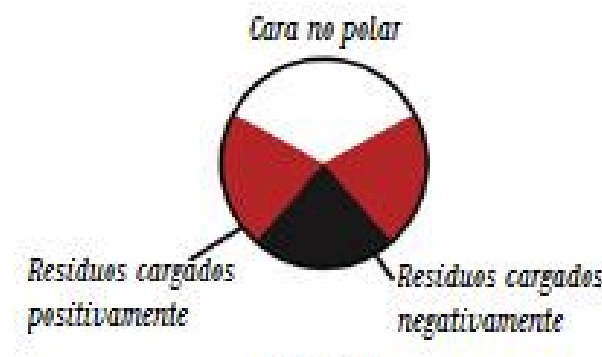

CLASE A

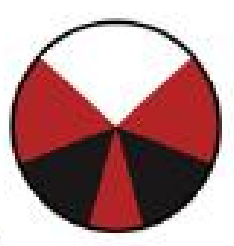

CLASE Y

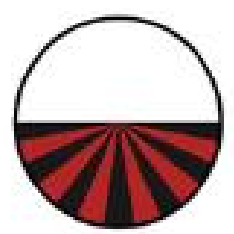

CLASE G

Figura 1.1: Representación esquemática de los modelos de rueda de "Schiffer-Edmunson" que representan las diferentes clases de hélices anfipáticas. ${ }^{5,6}$ 
Las hélices de clase A se encuentran en las regiones 44-65, 66-87, 121-142, 143-164, 165-186 y 187-208, las de clase G en el segmento 8-33, y las de clase Y en la región 8898, 99-120, 209-219 y 220-241 3,4 El análisis secuencial ha sugerido que la región codificada por el exón-3 forma una hélice G, y la región codificada por el exón-4 contiene 10 repeticiones o "tándem" de 11 a 22 residuos que forman hélices anfipáticas clase A. ${ }^{5,6}$

En circulación la apoA-I puede existir en estado libre ó complejada como HDL con diversa cantidad de lípidos y otras proteínas, en conformaciones discoidales y esféricas que son intercambiables de manera altamente dinámica mientras ocurren los procesos de transporte de lípidos desde y hacia las células para su utilización o catabolismo.

A fin de llevar a cabo esta función, la estructura de esta proteína es altamente flexible y adaptable. Sin embargo, llas propiedades termodinámicas de desplegado de apoA-I son distintas a las proteínas globulares típicas. En ensayos de desnaturalización térmica de apoA-I libre de lípidos se estimó que la energía libre de estabilización $\Delta \mathrm{G}^{\circ}$ $\left(37^{\circ} \mathrm{C}\right)$ es de aproximadamente $2,4 \mathrm{kcal} / \mathrm{mol}$ comparado a las $5-15 \mathrm{kcal} / \mathrm{mol}$ típico de las proteínas globulares ${ }^{7}$; Se demostró además por dicroísmo circular que apoA-I libre de lípidos posee propiedades identificables con el estado de "glóbulo fundido" definido como un plegamiento compacto intermedio, de estructura terciaria laxa con una estructura secundaria casi nativa ${ }^{8}$.

Por otra parte varios ensayos han tratado de dilucidar como se ensambla la apoA-I para formar las HDLs.

En la actualidad existe gran consenso apoyando un modelo donde las hélices anfipáticas de dos moléculas de apo se disponen en forma de "cinturón" alrededor de una bicapa lipídica, con el eje longitudinal de las hélices de ambas proteínas perpendicular a las cadenas acílicas de los ácidos grasos de los fosfolípidos, y el fragmento N-terminal plegado en forma de horquilla para maximizar la interacción con el dominio C-terminal ${ }^{9,10}$

Dada la estructura laxa de la apoA-I fue vedado el obtener la estructura cristalina de la molécula completa; Mei y Atkinson predijeron la estructura cristalina de la apoA-I $\Delta$ 185-243 (Figura 1.2); donde sugieren una dimerización en el ensamblaje de HDL; la región central funcionaría como bisagra, facilitando la conversión de dímero a monómero. Con un esqueleto semicircular formado a partir de las repeticiones antiparalelas, esta estructura permitió modelar la formación de partículas HDL 
discoidales $^{11}$ (Figura 1.3). El dominio central formaría un túnel para traslocar lípidos durante la interacción con lecitina colesterol aciltransferasa (LCAT) ${ }^{12}$.

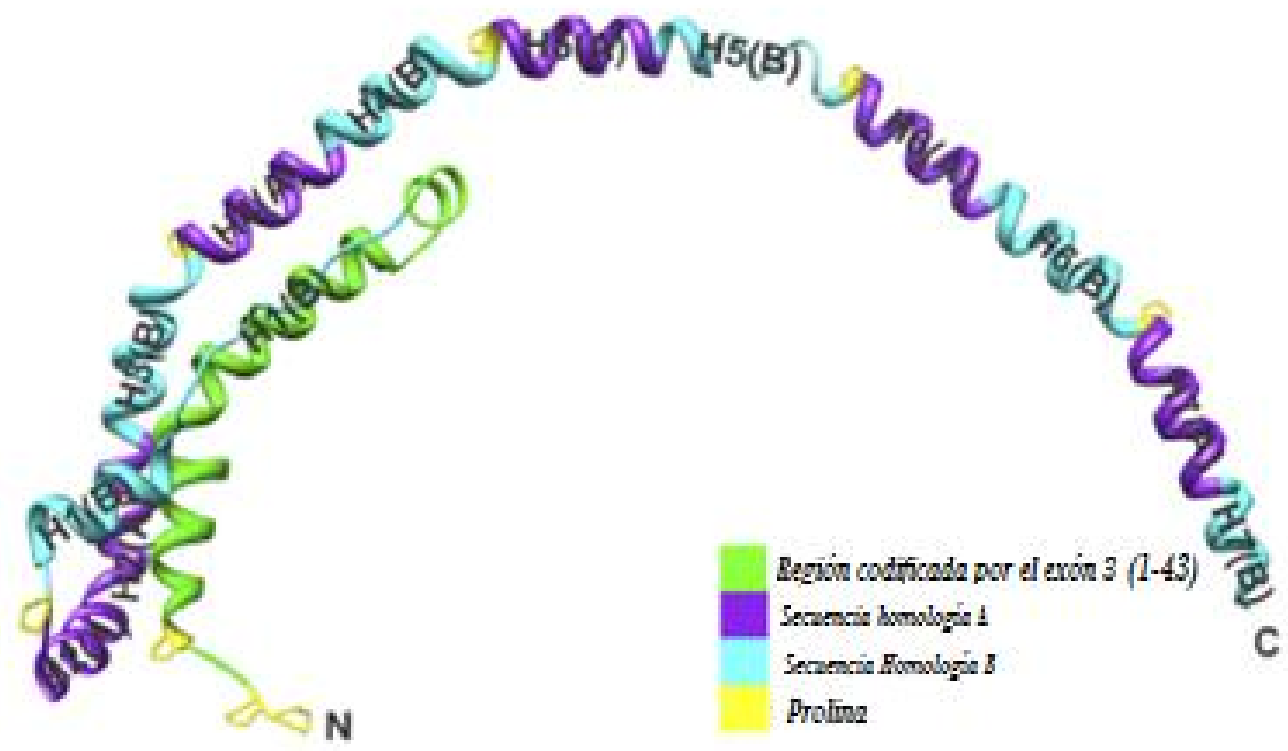

Figura 1.2: Estructura completa del monómero de apo A-I $\Delta(185-243)^{12}$.

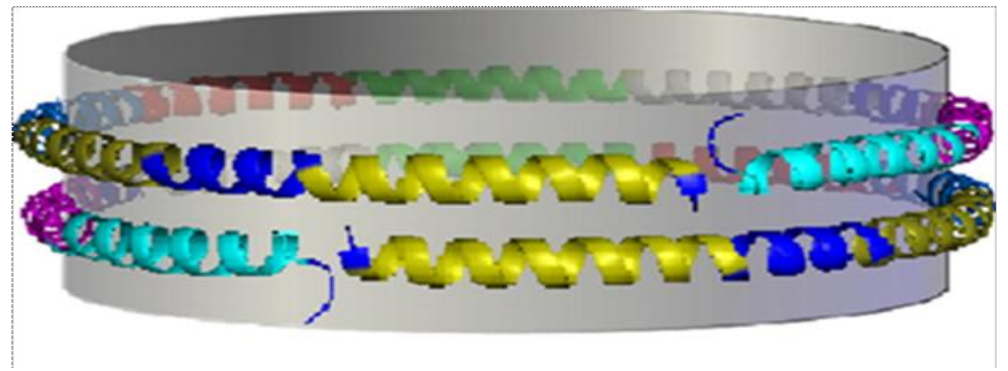

Figura 1.3: Disposición de apo A-I dimerizada al formar las HDLs discoidales. Cada hélice se representa con un color: Hélice 1, turquesa; Hélice 2, Púrpura; Hélice 3, Azul; Hélice 4, Gris; Hélice 5, Verde; Hélice 6, Rojo; Hélice 7, celeste; Hélice 8, amarillo oscuro; Hélice 9, azul marino, hélice 10, amarillo. ${ }^{~}$

\section{B. APOLIPOPROTEINA A-I. FUNCIÓN NORMAL}

La apoA-I es sintetizada principalmente en el hígado y en menor medida en el intestino. Una vez secretada al plasma, ávidamente se une a las superficies lipídicas pero también se intercambia fácilmente entre partículas lipoproteicas, jugando un rol clave en ambas, entrega de colesterol a los tejidos esteroidogénicos y en el llamado transporte reverso del colesterol (TRC), el proceso por el cual el exceso de colesterol libre es removido desde los tejidos periféricos, esterificado en plasma y transportado al hígado para su excreción. Este proceso es altamente complejo y motivo de extensos 
estudios a nivel mundial en los que, de manera unánime se le atribuye a la apoA-I una función anti-aterogénica, protegiendo contra el desarrollo de patologías vasculares. ${ }^{4}$

El colesterol celular está exquisitamente controlado y existen numerosas vías metabólicas para mantener un equilibrio celular crítico de los esteroles. Una amplia gama de elementos de respuesta a los esteroles y reguladores transcripcionales, tales como LXR, participan en la regulación coordinada de la transcripción génica para mantener el equilibrio del esterol celular ${ }^{13}$

Jolley y colaboradores ${ }^{14}$ señalaron que el TRC al hígado no está dictado por las concentraciones plasmáticas de HDL o apoA-I, sino que está determinado por eventos que ocurren en los órganos periféricos. Como se ilustra en la figura 1.4, el flujo de colesterol en la mayoría de las células se produce en las etapas iniciales a través del movimiento de colesterol no esterificado y fosfolípidos de la membrana plasmática a una partícula aceptora en el compartimiento intersticial. Mientras que este proceso puede ocurrir por des absorción, el transporte activo depende del transportador de esteroles de membrana plasmática celular, ABCA1. Curtiss y colaboradores determinaron que la apoA-I debe disociarse de las HDLs esféricas para poder interaccionar con este receptor.

Después de transferir el exceso de colesterol libre desde las células a apoA-I pobre en lípidos, se forman las partículas HDL discoidales; Las $\alpha$-hélices 6 y 7 de apoA-I activan la LCAT que forma ésteres de colesterol (CE), generándose así las partículas de HDL esféricas que llegan al hígado para su excreción ${ }^{13}$ 


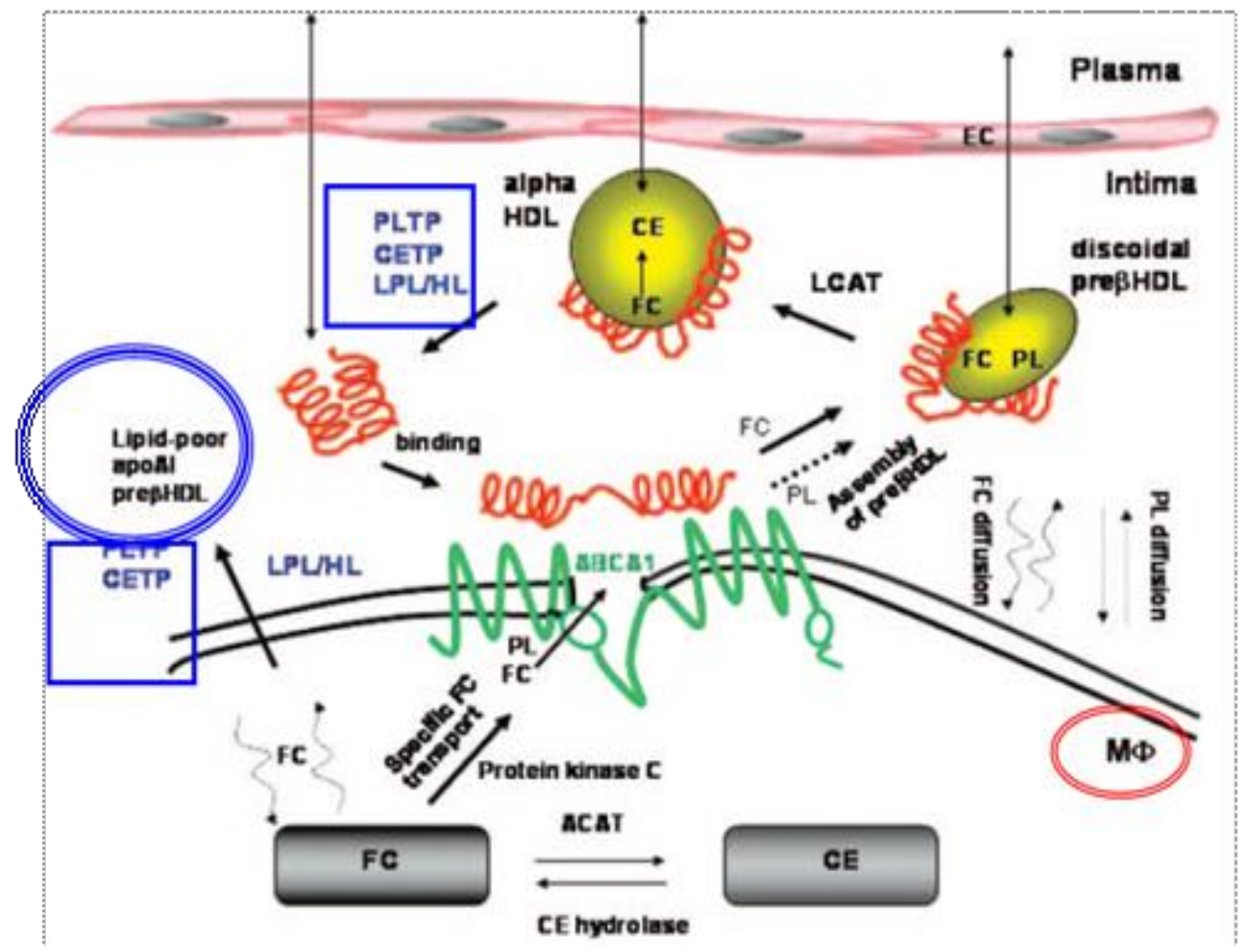

Figura 1.4: Diagrama esquemático de las posibles formas de HDL intersticial presentes en la íntima de una lesión aterosclerótica en estrecha proximidad a una célula espumosa. Mientras que la forma más abundante es la partícula HIL esférica $\alpha$, debido a que es la principal especie de HIDL en el plasma, esta especie tiene una baja afinidad por el transportador de membrana ABCAl. El sustrato ideal para ABCAl, apo A-I libre 0 pobre en lípidos, se genera en la íntima a partir de HDL esférica o ingresa libre desde circulación, adquiere colesterol libre y fosfolípidos para formar HDL pre- $\beta$ discoidales. Esta luego puede ir al plasma o convertirse en HDL esférica por LCAT y volver al plasma. ${ }^{13}$

No menos importantes en la prevención de la enfermedad cardiovascular (ECV) son los roles asignados a la apoA-I y las HDL en los procesos requeridos para mantener el funcionalismo y la viabilidad endotelial. En este aspecto se sabe que, entre otras funciones la apoA-I, favorece la vasodilatación mediada por Oxido Nítrico ${ }^{15}$, inhibe la secreción endotelial de moléculas de adhesión para neutrófilos y macrófagos ${ }^{16}$, e inhibe la apoptosis de células endoteliales ${ }^{17}$. Estas actividades son vitales a fin de evitar complicaciones asociadas a patologías metabólicas como la diabetes, dislipemias y aterosclerosis. Como es de esperar, estas funciones no están aisladas de las anteriores mencionadas, ya que la acumulación de colesterol celular es citotóxico y lleva a la célula a una muerte temprana, por lo que sería probable que su remoción de células endoteliales favorezca la viabilidad y funcionalidad. ${ }^{18}$ 


\section{AMILOIDOSIS Y APOLIPOPROTEINA A-I}

Amiloidosis es una patología caracterizada por el depósito o infiltraciones extracelulares de componente fibrilar amiloide insoluble, lo cual causa una progresiva disfunción del órgano que afecta ${ }^{19}$. Pueden ser clasificadas según la proteína precursora y la distribución amiloide tanto en sistémicas o localizadas. Las principales amiloidosis sistémicas primarias incluyen: amiloidosis por cadenas livianas, secundaria o reactiva (AA), sistémica senil (SSA), hereditaria o familiar (FA), y amiloidosis relacionada a hemodiálisis (ß2-microglobulina) ${ }^{20}$.

Los depósitos amiloides son homogéneos hialinos y eosinofílicos los cuales a través de la tinción con rojo congo generan una birrefrengencia verde manzana bajo luz polarizada. Las fibrillas tienen entre 7-10 nm de diámetro y se observan fácilmente por microscopía electrónica ${ }^{21}$. Esta característica constituye el diagnóstico positivo de amiloidosis en órganos de pacientes afectados.

El factor en común a todas las amiloidosis es el plegamiento anómalo de proteínas extracelulares. Se trata de un proceso dinámico, el cual ocurre en paralelo como una alternativa al plegado fisiológico que genera agregados de proteínas tóxicas e insolubles que son depositados en tejidos principalmente en una conformación en hoja beta $^{19}$

A la fecha, hay al menos 21 proteínas relacionadas a esta patología. Diferentes amiloidosis hereditarias son debido a la sola presencia de mutaciones puntuales que aumentan la conducta patológica de la proteína afectada. Sin embargo, la razón por la que se produce la vía a la patogenicidad parece depender de un gran número de factores, tanto intrínsecos de la secuencia proteica- conformación o al micro-entorno local en la que las proteínas ejercen su función. Por otra parte, un extenso campo de investigación indica que, además de las fibras que son el signo de esta enfermedad, las especies más desorganizadas y solubles podrían modular la citotoxicidad de las conformaciones de proteínas mal plegadas ${ }^{22,23}$.

\section{APOLIPOPROTEÍNA A-I Y AMILOIDOSIS}

La existencia de flexibilidad estructural en la apoA-I es un hallazgo común en las proteínas involucradas en amiloidosis. La aparición de mutaciones en la secuencia primaria puede incrementar además la tendencia a la agregación. Así, distintas variantes

puntuales de la apoA-I fueron detectadas en pacientes con dicha enfermedad. Las 
amiloidosis hereditarias causadas por apoA-I se caracterizan por un depósito progresivo de fibras amiloides constituidas generalmente por fragmentos de la región $\mathrm{N}$-terminal de la proteína en las lesiones ${ }^{4}$. Al momento fueron descriptas más de 50 variantes naturales de apoA-I, y cerca de un tercio de las mismas están asociadas con amiloidosis familiar $^{24}$.

La localización y severidad de las lesiones es variable, involucrando varios órganos como riñón ${ }^{25,26}$, hígado $^{27}$ y corazón $^{28}$. Otros tejidos involucrados menos frecuentemente son piel, testículo, laringe y nervios periféricos ${ }^{29,30}$.

En la tabla 1.1 se detalla algunas variantes y el órgano u órganos afectados.

Tabla 1.1: Variantes de Apo A-I asociadas a amiloidosis ${ }^{24}$

\begin{tabular}{|c|c|}
\hline Variante & Órganos que afecta \\
\hline $\mathbf{W t}$ & Aterosclerosis Senil \\
\hline Gly26Arg (IO & Riñon, SNP (PAF) \\
\hline Trp50Arg & Falla Renal \\
\hline Leu60Arg & Falla Renal \\
\hline Leu64Pro & Falla Renal \\
\hline Leu75Pro & Falla renal, hepática y gastrointestinal \\
\hline Leu90Pro & Cardiomiopatía, amiloidosis cutánea \\
\hline Lys107del & Amiloidosis de la íntima arterial/Aterosclerosis \\
\hline Ala154fs & Amiloide Renal \\
\hline Leu170Pro & Amiloidosis laríngea \\
\hline Arg173Pro & Cardiomiopatía, amiloidosis cutánea y laringea \\
\hline Leu174Ser & Cardiomiopatía \\
\hline Ala175Pro & Amiloidosis laríngea \\
\hline Leu178His & Cardiomiopatía, amiloidosis cutánea y laringea \\
\hline
\end{tabular}

Además, y de manera altamente interesante, depósitos de amiloide de apoA-I en la íntima de la aorta han sido asociados frecuentemente con placas ateroscleróticas, en particular en pacientes con el mutante de deleción Lys107-0 ${ }^{31}$. La naturaleza de la mutación en la apoA-I también es sumamente variable. Varias de estas mutaciones se basan en el reemplazo de un residuo de un amino ácido neutro (Gly26, Trp50, Leu60) en la región $\mathrm{N}$-terminal por el residuo del amino ácido básico Arginina, lo cual produce un cambio de la carga neta de la proteína ${ }^{4,32,33,34}$. Similares mutaciones en otros 
dominios no inducen la formación de depósitos proteicos, mostrando que la localización de la mutación influye en la patogenicidad ${ }^{35}$. Eriksson y colaboradores (2009) han identificado dos "regiones clave o hot-spots" en la secuencia de la apoA-I en la que la mayor parte de las mutaciones son descriptas ${ }^{36}$. Alrededor del 50\% de las mutaciones encontradas implica la sustitución de residuos en la región que abarca desde el aminoácido 50 a 93, conduciendo principalmente a los pacientes a sufrir de amiloidosis hepáticas o renales ${ }^{37}$. Por otra parte, un gran número de mutaciones puntuales para el tramo entre los residuos 173 a 178 provocó principalmente amiloidosis del corazón, de la laringe o de la piel. Sin embargo a pesar de la localización de la mutación, la proteólisis entre los residuos 83 y 93 está involucrada, dando como resultado que el extremo N-terminal es la forma predominante de la proteína encontrado en depósitos de fibrillas de amiloide en lesiones de pacientes ${ }^{38}$. En la figura 1.5 se muestra, en el modelo de dímero de Mei y Atkinson, las distintas posiciones de las mutaciones más frecuentes de apoA-I ${ }^{39}$. Cabe mencionar que, en nuestra opinión, al ser ésta una proteína que aún no es extensamente estudiada, numerosas mutaciones aun no han sido descriptas, y de hecho en la actualidad se han identificado más variantes luego de la secuenciación genómica, campo vacante aún en Argentina.

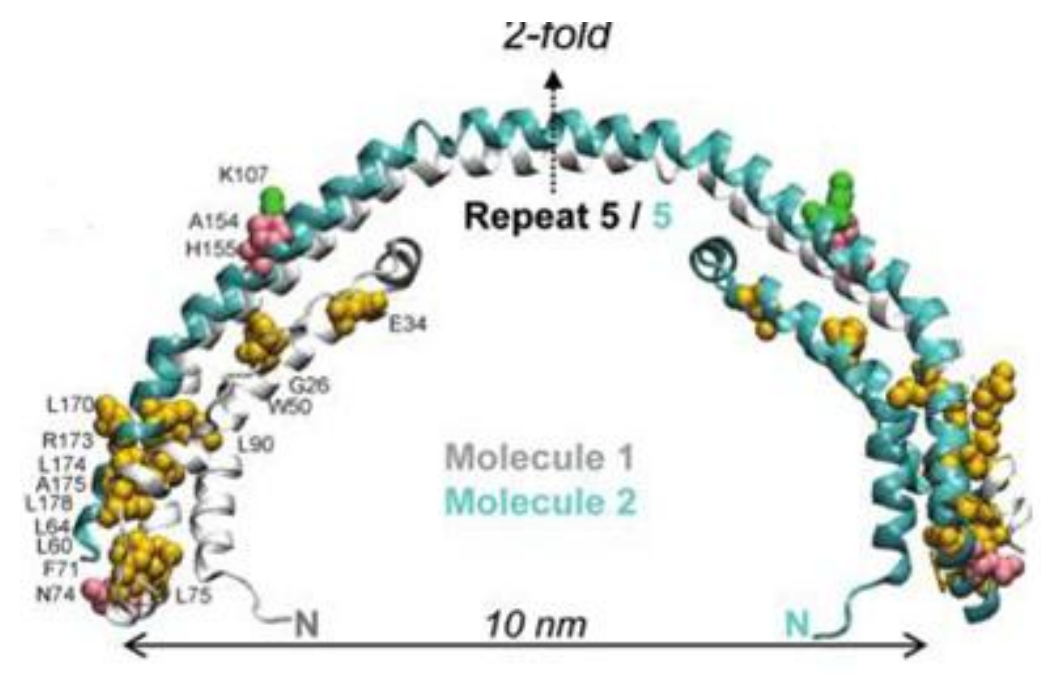

Figura 1.5: Localizaciones de mutaciones amiloidogénicas en la estructura de la apoA-I. En la estructura cristalina de apoA-I $\Delta(105-243)$, se muestra el dímero comprendido por una molécula (marcada en gris) y la molécula 2 (turquesa). El eje cristalográfico dos veces pasa por el medio de la secuencia repetida 5 (aminoácidos 121-142). Cada residuo mutado se representa con un color, indicando: sustituciones puntuales (amarillo); deleción (Verde); mutaciones de desvío de marco de lectura (rosa). ${ }^{39}$

A fin de estudiar aspectos estructurales que participen en la patogeniciad de las variantes de apoA-I, en el laboratorio se han estudiado dos variantes, un mutante de 
deleción Lys107-0, induciendo amiloidosis asociada a aterosclerosis $\operatorname{grave}^{37} \mathrm{y}$ Gly26Arg, asociado con polineuropatía e insuficiencia renal ${ }^{40}$. Se han identificado eventos comunes y específicos que podrían mediar el mal plegamiento y la patología ${ }^{41}$. Aprovechando las experiencias adquiridas, decidimos analizar las consecuencias de la mutación Arg173Pro, una variante asociada a cardiopatía y compromiso de la piel ${ }^{29,4}$

En el mundo no se conoce a ciencia cierta ni la epidemiología ni el impacto que causa esta enfermedad en la población. En Argentina desde el 2010 varios centros de salud tratan de incorporar un registro nacional de Amiloidosis para tener un valor epidemiológico de la patología, esto surge a consecuencia del aumento del diagnóstico de la enfermedad en estadios terminales y ante la necesidad de diagnosticar la amiloidosis tempranamente a fin de implementar mejores herramientas terapéuticas. En su revista el servicio de patología del Hospital italiano de Bs As registró 107 pacientes de los cuales confirmaron diagnóstico $n=60(56 \%)$ y el resto fueron sospechosos de amiloidosis $n=47$ (44); En las amiloidosis confirmadas, la distribución por tipo de amiloidosis fue: 43\% (26) localizada, 10\% (6) AA, 35\% (21) AL, 5\% (3) transtirretina, $5 \%$ (3) no tipificada y $3 \%$ (2) senil ${ }^{42}$. A su vez, la distribución por órganos con el tipo de amiloidosis fue la siguiente (Tabla 1.2):

Tabla 1.2: Afectación por órgano de acuerdo con el tipo de amiloidosis ${ }^{42}$.

\begin{tabular}{|c|c|c|c|c|c|c|}
\hline Afectación por sistemas & Cadenas livianas & Sistémica & Transtiretina & Localizada & Senil & No tipificada \\
\hline Cardiovascular & $38 \%(8 / 21)$ & $40 \%(2 / 5)$ & 0 & $11 \%(3 / 26)$ & $100 \%(1 / 1)$ & $66 \%(2 / 3)$ \\
\hline Renal & $90 \%(19 / 21)$ & $100 \%(6 / 6)$ & 0 & $11 \%(3 / 26)$ & $50 \%(1 / 2)$ & $66 \%(2 / 3)$ \\
\hline Sistema digestivo & $33 \%(7 / 21)$ & $66 \%(4 / 6)$ & $66 \%(2 / 3)$ & $11 \%(3 / 26)$ & 0 & $33 \%(1 / 3)$ \\
\hline Sistema neurológico & $9 \%(2 / 21)$ & $33 \%(2 / 6)$ & $100 \%(3 / 3)$ & 0 & 0 & 0 \\
\hline Ortalmica & $14 \%(3 / 21)$ & 0 & 0 & $15 \%(4 / 26)$ & 0 & 0 \\
\hline Muscular & $9 \%(2 / 21)$ & $16 \%(1 / 6)$ & 0 & $3 \%(1 / 26)$ & 0 & 0 \\
\hline
\end{tabular}

En este informe, un 5\% era amiloidosis no tipificada, es decir alrededor de 3 pacientes quizás pudieran tener amiloidosis debidas a proteínas entre las que se incluye la apoA-I. He aquí nuestro ahínco en profundizar este diagnóstico, en un inicio en la Localidad de La Plata y luego extenderlo a la población asistente a distintos centros de salud.

\section{E. MICROAMBIENTE Y CONFORMACIÓN PROTEICA}

El hallazgo de la apoA-I en forma de agregados de tipo amiloide, en lesiones ateroscleróticas, seniles ó severas abre distintas posibilidades 1) el cambio estructural inducido por la mutación provoca el depósito o catabolismo de la misma, determinando 
la pérdida o disminución de las funciones proteicas (anti-apoptótica de células endoteliales, reguladora de la homeostasis de colesterol, etc.) o 2) que las variantes mutantes sean más susceptibles de ser modificadas o de inducir un cambio de escenario pro-inflamatorio crónico que la proteína con la secuencia nativa.

Estudios previos del laboratorio sugieren que la proteína posee una tendencia intrínseca a transformarse en pro-amiloidogénica ${ }^{43}$, pero además, que distintos mecanismos podrían estar participando en la determinación de la patogenicidad.

Merlini y colaboradores plantean que las mutaciones (puntuales o no) pueden inducir desde la síntesis de las proteínas una propensión intrínseca a su plegamiento anómalo induciendo amiloidosis, pero las influencias extracelulares, como ser $\mathrm{pH}$, proteasas, cambios de temperatura, ambientes oxidativos etc., pueden ocasionar cambios conformacionales, generando oligómeros o protofibrillas que activarían mecanismos apoptóticos por parte de las células. (Figura 1.6)

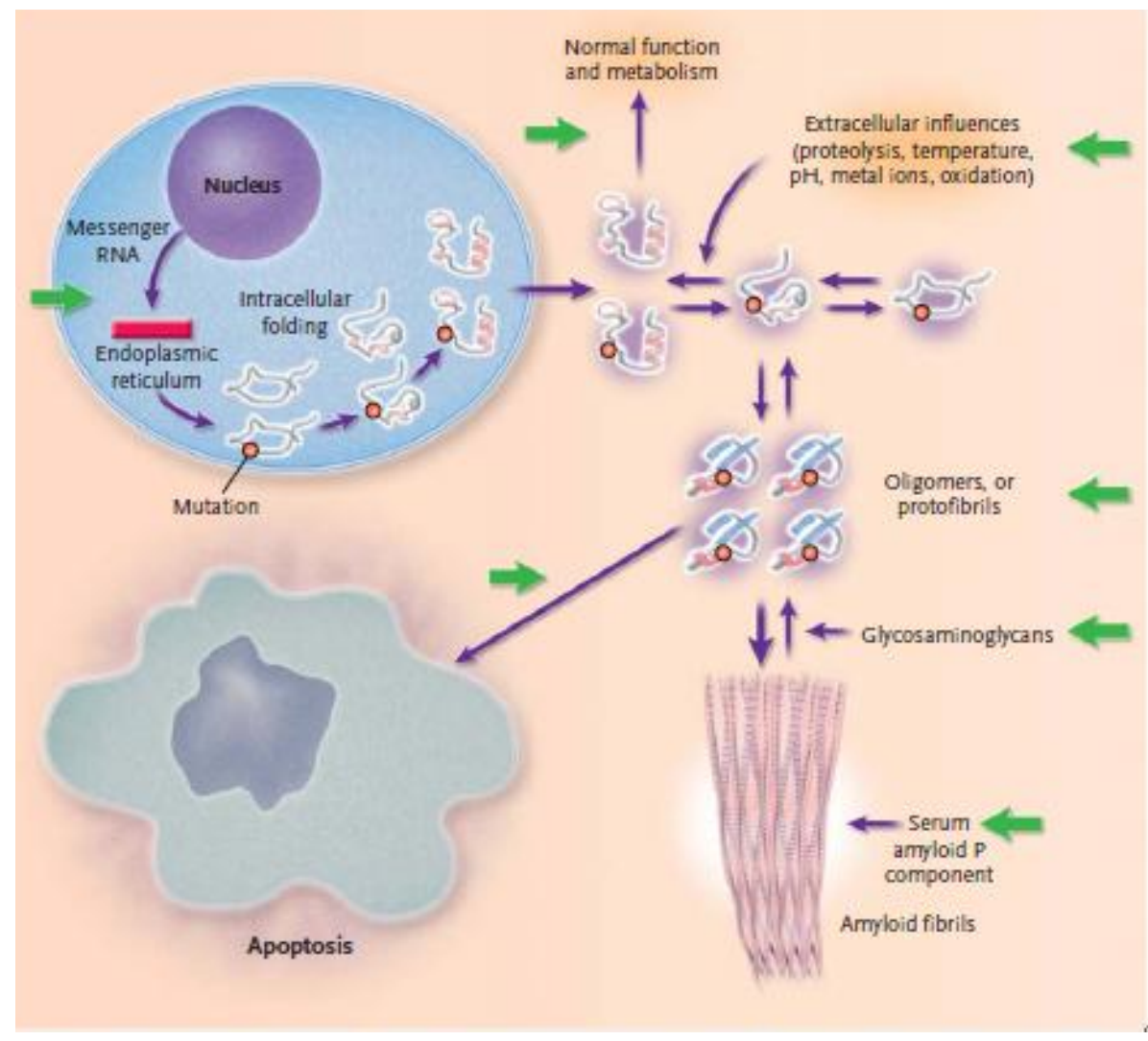

Figura 1.6: Destinos potenciales por una cadena polipeptídica recién sintetizada en un paciente heterocigota para una mutación amiloidogénica ${ }^{19}$

Así, distintos eventos generales o específicos del entorno celular podrían participar de distinta manera en la determinación de los mecanismos patogénicos de 
apoA-I. Entre otros eventos se ha demostrado previamente que el microambiente de los lípidos podría inducir un cambio conformacional de la apoA-I o péptidos derivados de los dominios terminales ${ }^{44,45}$. La presencia de lípidos cargados negativamente en la membrana plasmática es una característica común asociada a la aterosclerosis u otros eventos inflamatorias crónicos locales que inducen apoptosis.

Por otra parte se ha sugerido para distintas proteínas, que su interacción con componentes de la matriz extracelular como ser los glucosaminoglucanos (polímeros de disacáridos constituidos por un aminoazúcar y un ácido urónico que están sulfatados y unidos a proteínas, formando proteoglicanos ${ }^{46}$ puede llevar a la estabilización de la microfibrillas, constituyendo las fibrillas amiloides que se depositan en los tejidos causando su disfunción ${ }^{47}$. Se sabe que los GAGs desempeñan funciones complejas en eventos celulares tan diversos como la proliferación o envejecimiento ${ }^{48,49}$. Entre otros hallazgos se demostró recientemente que el dermatán sulfato de bajo peso molecular modula la proliferación celular endotelial y la migración ${ }^{50}$. Vale la pena señalar que evidencia científica apoya que los GAGs podrían participar en la amiloidogénesis in vivo, tal vez incluso en un papel protector, mediando en la conversión de los oligómeros solubles proteotóxicos en fibrillas de amiloide menos tóxicas y relacionados a los agregados- $\beta$-hoja entrecruzada ${ }^{51}$.

La comprensión de la interacción de las proteínas amiloides con GAGs es definitivamente una ventaja en el diseño de compuestos anti-amiloide como nuevos agentes terapéuticos para el tratamiento de enfermedades amiloidóticas. Basado en estudios anteriores, una nueva clase de compuestos están diseñados para interferir con las interacciones entre proteínas y GAGs y por lo tanto podrían ser apropiados para inhibir la polimerización de las fibrillas de amiloide y el depósito de las fibrillas en los $\operatorname{tejidos}^{52}$. Estos estudios implican en especial grupos sulfato con diferente eficacia in vivo o en modelos in vitro. Aunque estos estudios no están todavía en una "fase" clínica, es una estrategia prometedora para inhibir la agregación patológica de proteínas amiloides.

En esta línea de pensamiento, las variantes naturales de apoA-I con mutaciones en el residuo 173, plantean un interrogante muy interesante. La variante Arg173Pro fue asociada en pacientes con amiloidosis cardíaca y cutánea ${ }^{29}$. Las razones que llevan a este comportamiento de la proteína son altamente desconocidas ya que no existen caracterizaciones biofísicas o bioquímicas de este mutante. Sin embargo, otra mutación natural en el mismo residuo (Arg173Cys) induce un efecto opuesto en la relación 
estructura-función de la apoA-I. A pesar del hecho de que estos pacientes poseen bajo nivel de HDL, distintos efectos protectores fueron propuestos de ser inducidos por esta variante que disminuyen el riesgo de enfermedad cardiovascular: 1) esta apolipoproteína induce mayor actividad de la enzima óxido nítrico sintetasa en células endoteliales de cordón umbilical (eNOS) y es más efectiva para disminuir la expresión de factores de adhesión mediada por el factor de necrosis tumoral $\alpha^{53}$; 2) Complejos de apoA-I Arg173Cys y fosfolípidos son más eficientes para remover colesterol desde fibroblastos o macrófagos en cultivo que los mismos complejos con la proteína nativa ${ }^{54}$ y 3 ) en modelo de ratones, se observó que la inyección de estos complejos reduce el contenido de lípidos y macrófagos en lesiones aórticas ${ }^{55}$.

\section{F. ATEROSCLEROSIS Y AMILOIDOSIS}

La aterosclerosis es una enfermedad caracterizada por un engrosamiento y rigidez de la pared arterial debido al depósito de lípidos en la íntima rodeados de tejido fibroso, con la adhesión de células sanguíneas, proliferación de células de la pared arterial, y unión de carbohidratos y calcio que constituyen la placa ateromatosa ${ }^{56}$.

El endotelio vascular tiene la capacidad de sintetizar muchísimas moléculas, con funciones agónicas o antagónicas, para equilibrar los fenómenos en ambas direcciones

Cuando éste reduce su capacidad de mantener el delicado equilibrio funcional se crean condiciones que facilitan su penetración por los lípidos y los leucocitos, se encienden mecanismos inflamatorios que involucran el reclutamiento y activación de células del sistema inmune. La inflamación tiene una respuesta vascular, la cual depende principalmente de las células endoteliales, y una repuesta celular que involucra células del sistema inmune como lo son neutrófilos y macrófagos entre otras varias. Las células endoteliales normalmente se encuentran arrestadas, pero ante señales proinflamatorias son activadas y experimentan cambios fenotípicos significativos. La activación puede ser mediada por un receptor de membrana asociado a proteína $\mathrm{G}$ o puede deberse a la presencia de citoquinas pro-inflamatorias como TNF- $\alpha$ e IL-1.

Así se inicia la instalación de las células espumosas, matriz de la estría grasa, constituyendo el primer paso de la formación de la placa ateromatosa.

Las lipoproteínas de baja densidad oxidadas $\left(\mathrm{LDL}_{\mathrm{ox}}\right)$ se comportan como potentes agentes inflamatorios: estimulan la expresión de moléculas de adhesión sobre 
células endoteliales, tienen actividad quimioatractante sobre monocitos, promueven su diferenciación a macrófagos e inhiben su movilidad.

Las HDL asumen un rol como agente anti-aterogénico, extensiva investigación estadística reporta que la concentración de HDL es inversamente proporcional al riesgo ateroesclerótico. Esto se debe (y se atribuyó durante mucho tiempo) a su habilidad para promover la remoción de colesterol desde las células como fue mencionado más arriba. Por otra parte, ante infecciones, síndrome metabólico o enfermedades vasculares, las HDLs pueden adquirir capacidad pro-inflamatorias y pro-aterogénicas ${ }^{57}$.

En base a lo expuesto, estudios previos de nuestro y de otros grupos sugieren que la participación de distintos eventos micro ambientales podrían jugar un rol determinante en el equilibrio de la relación estructura-función-patogenicidad de la apoA-I humana, y plantea la posibilidad de asociar la génesis de dos enfermedades crónicas como la aterosclerosis y la amiloidosis. La hipótesis de que esta proteína pueda, ante determinadas condiciones iniciar una respuesta pro-inflamatoria es altamente interesante, ya que varias de sus funciones naturales en la protección contra enfermedades cardiovasculares sugieren acción anti-oxidante $\mathrm{o}$ anti-inflamatoria. Entonces se plantea la siguiente hipótesis: es la amiloidosis asociada a apoA-I una patología debida a pérdida de función, o al inicio de eventos debidos a daño celular inducido por proteínas mal plegadas. En este sentido el campo a explorar ofrece un desafío único ya que muy poca información estructural o bioquímica apoya una u otra hipótesis. 


\section{HIPÓTESIS DE TRABAJO}

I. La sustitución de Arginina por Prolina en la posición 173 induce un cambio estructural que resulta en una conformación menos estable con tendencia a la agregación

II. El cambio conformacional de esta variante puede exponer mayores sitios de unión con ligandos putativos, por ejemplo con GAGs.

III. Arg173Pro posee una mayor susceptibilidad al clivaje proteolítico por proteasas liberadas del entorno.

IV. La apoA-I Arg173Pro es capaz de activar macrófagos e inducir una respuesta pro-inflamatoria. 


\section{OBJETIVO GENERAL}

Identificar los posibles mecanismos biofísicos o bioquímicos que determinen la amiloidosis debida al mutante natural de apoA-I Arg173Pro.

\section{OBJETIVOS ESPECÍFICOS}

I. Construir la variante de apoA-I Arg173Pro, detectada en pacientes con amiloidosis.

II. Estudiar mediante métodos biofísicos características de plegamiento de esta variante, a fin de determinar parámetros estructurales que puedan inducir al plegamiento anómalo y la relación con la función proteica.

III. Estimar el procesamiento pro-toxico de las proteínas, simulando una respuesta pro-inflamatoria.

IV. Determinar la posible activación de respuesta pro-inflamatoria a partir de la variante mencionada

V. Estudiar la interacción de Arg173Pro con modelos de lípidos negativos y de GAGs.

VI. Estudiar el posible efecto de cargas negativas sobre la interacción de Arg173Pro con componentes de la matriz extracelular usando modelos de polímeros sintéticos. 


\section{MATERIALES Y MÉTODOS}

\section{A. OBTENCIÓN DE APOA-I WILD TYPE, WT Ó MUTADA (ARG173PRO) MEDIANTE EXPRESIÓN A PARTIR DE CULTIVOS BACTERIANOS.}

\section{Obtención y amplificación de vectores para clonación: plásmidos.}

Los plásmidos son secuencias de DNA de doble cadena, de origen bacteriano, que permiten la incorporación y manipulación de un gen específico, ya sea de origen procariótico o, como en nuestro caso, el cDNA de origen eucariótico a bacterias para la expresión de la proteína de elección; en este trabajo se utilizaron los plásmidos pET30, de Novagen, cuya secuencia permite la selección de bacterias subclonadas gracias a que le confiere resistencia al antibiótico kanamicina. En el lugar de inserción del gen (polilinker) el plásmido incorpora a la secuencia del gen una cola de poli-histidina directamente al inicio de la secuencia N-terminal de la proteína para su posterior purificación, esta cola de poli-histidina es eliminada de la secuencia de aminoácido como se explicará más adelante (Figura 4.1)

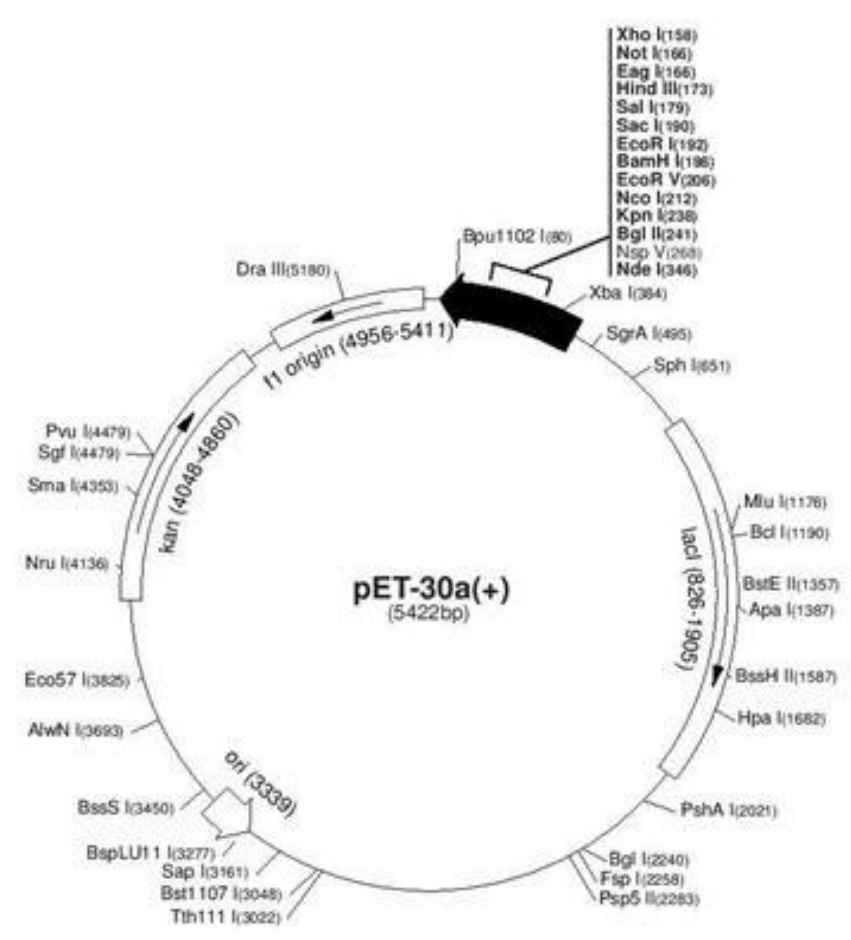




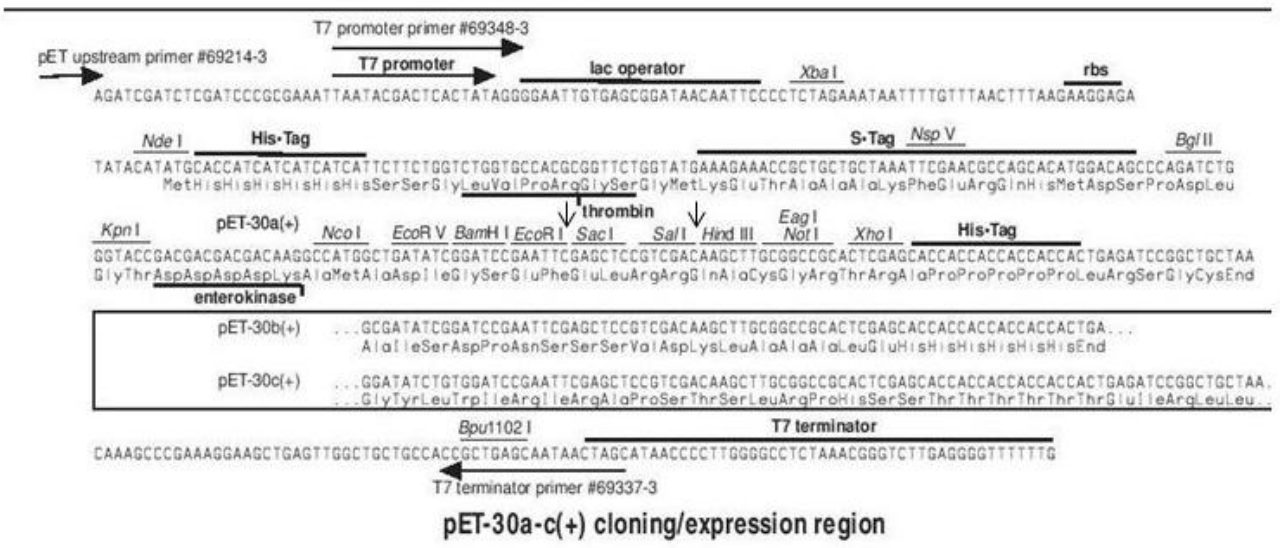

Figura 4.1 Mapa plasmídico del vector pet30

En la figura 1 se muestra el esquema general del plásmido en donde se observa la región del poli-linker, el sitio de replicación y el gen que codifica la resistencia a kanamicina. En la parte inferior se detalla la secuencia de nucleótidos y los sitios de restricción en la región donde se inserta el gen de interés (indicado con flechas).

La adición de Isopropil Tiogaláctosido (IPTG) induce al operón lac, lo que promueve la expresión de los genes que se encuentran directamente a continuación en la secuencia del operón, incluyendo en esta construcción una secuencia aminoacídica rica en residuos Histidina (His Tag), lo que facilita la posterior purificación de la proteína de elección insertada.

La obtención de plásmidos a partir de bacterias se realiza a pequeña escala (miniprep) en donde se obtienen microgramos de DNA plasmídico; se utilizan para tal fin dos protocolos diferentes cuyo fundamento es la lisis alcalina con Dodecil Sulfato de Sodio (SDS) para producir la liberación del plásmido de las bacterias, dejando aparte el DNA cromosómico junto con restos de pared celular. Una vez que estos restos son separados, se purifica el DNA plasmídico a partir de la solución remanente. Para tal fin se utilizaron dos técnicas: una de bajo costo y casera $^{58}$, utilizada para verificar ausencia de contaminación o para obtener plásmidos para posteriores transformaciones, y la otra mediante un kit comercial de Qiagen, utilizado para obtener plásmido con una pureza considerable, adecuado para su secuenciación o posterior manipulación en biología molecular. Por último se determinó absorbancia a $260 \mathrm{~nm}$ (Long de onda a la que absorben los ácidos nucleicos) y a $280 \mathrm{~nm}$ (Long de onda a la que absorben las 
proteínas). De la relación 260/280 se verificó que la solución obtenida no se encuentra contaminada con proteínas. El valor adecuado de esta relación es mayor a 1,8.

\section{Tratamiento de bacterias para conferirles competencia}

En este trabajo se utilizaron huéspedes bacterianos de expansión de plásmido (JM109) y de expresión de proteínas (BL21 DE3), ambas de Novagen, derivados de líneas de E. Coli; para cualquiera de los dos casos se requiere la incorporación del plásmido en las bacterias mediante el proceso de "transformación", para lo cual previamente deben manipularse las mismas para ser aptas para tal paso, o sea hacerlas "competentes". Para tal fin se utilizó el método de Inoué. La competencia de las bacterias se logró con un crecimiento a baja temperatura $\left(24^{\circ} \mathrm{C}\right)$ hasta una Densidad Óptica de 0.5 a $600 \mathrm{~nm}$, y posteriores lavados con soluciones de $\mathrm{CaCl} 2-\mathrm{MgCl} 2$; El primer paso de este proceso altera la composición lípidica de la membrana, haciéndola más "permeable" al plásmido. Se postula que $\mathrm{CaCl} 2-\mathrm{MgCl} 2$ compleja la membrana facilitando el pegado del plásmido y posterior introducción del mismo a la bacteria ${ }^{59}$; una vez obtenidas se las guarda en solución con glicerol estéril al $20 \%$ a $-80{ }^{\circ} \mathrm{C}$. Este protocolo es muy sencillo y económico, pero la eficiencia de transformación es baja y pierden la competencia muy rápidamente.

\section{Transformación}

El método por el cual se incorpora un plásmido dentro de bacterias se denomina transformación, y puede ser realizado por electroporación o shock térmico. El utilizado en este trabajo fue transformación por shock térmico. Se pusieron en contacto $0.2 \mathrm{ml}$ de bacterias competentes con una solución del plásmido $(20 \mu \mathrm{l})$, por el término de 30 minutos a $4{ }^{\circ} \mathrm{C}$, y luego se colocó el tubo en un baño a $42{ }^{\circ} \mathrm{C}$ durante 90 segundos. Inmediatamente se enfrió en baño de hielo, y se le agregó $0.8 \mathrm{ml}$ de medio LuriaBertani (LB). Se incubó a $37^{\circ} \mathrm{C}$ durante una hora, y por último se centrifugó para obtener un precipitado de bacterias, las cuales fueron tomadas con una punta de pipeta y distribuidas en una placa de agar al $1.5 \%$ con medio LB (LB-agar), más el antibiótico adecuado (en nuestro caso kanamicina $30 \mu \mathrm{g} / \mathrm{ml}$ ). Se dejó la placa a temperatura ambiente por una hora, para luego incubarla por 24 horas a $37^{\circ} \mathrm{C}$ para que desarrollen las bacterias transformadas, que son aquellas que poseen resistencia al antibiótico, característica conferida en la secuencia plasmídica. Luego se tomaron una a una las 
colonias y se las creció en medio LB líquido con antibiótico; la mitad de medio se separó para comprobación del proceso (purificación del plásmido y análisis de secuencia ó expresión), y el resto se guardó en glicerol $20 \%$ a $-80^{\circ} \mathrm{C}$ para su conservación.

Medio de cultivo Luria-Bertani (LB):

$\checkmark 10$ gr de triptona bacteriológica

$\checkmark 5$ gr de Extracto de levadura

$\checkmark 10$ gr de $\mathrm{NaCl}$

$\checkmark$ Se lleva a $\mathrm{pH}$ de 7.4 y a volumen de un litro, para luego esterilizar por 15 minutos a $120^{\circ} \mathrm{C}$.

\section{Construcción del mutante de apoA-I}

La amplificación de cadenas de ácidos nucleicos ha sido posible gracias al acceso de oligonucleótidos de origen sintético y a la obtención de polimerasas, este hecho ha logrado la clonación, y modificación de genes in vitro y en forma rápida, gracias a la denominada Reacción en Cadena de la Polimerasa (PCR), la que permite obtener, de una región determinada del genoma, millones de copias, siempre que una parte de su secuencia sea conocida. La técnica consiste básicamente en diseñar en una primera etapa dos oligonucleótidos iniciadores o "primers" a partir de la secuencia conocida, cada uno complementario a una de las hebras de la doble hélice y en extremos opuestos. El éxito de la técnica se logra gracias al uso de un enzima DNA polimerasa aislada de una bacteria termófila que es estable a muy altas temperaturas (Pfu), de forma tal que no se desnaturaliza al aumentar la temperatura en sucesivos ciclos. Cuando se calienta la doble hebra y posteriormente se enfría en presencia de exceso de los "primers", éstos se hibridizan con las secuencias complementarias de DNA genómico, actuando como sitio iniciador; luego en presencia de los cuatro desoxinucleótidos y de la DNA polimerasa, se elonga la secuencia flanqueada por los primers. Cuando se repite el procedimiento los fragmentos recién sintetizados sirven de moldes, y en pocos ciclos el producto que predomina es una secuencia única de DNA cuya longitud corresponde a la distancia de nucleótidos que hay entre los primers. El esquema general de la técnica se muestra en la figura $4.2^{58}$. 


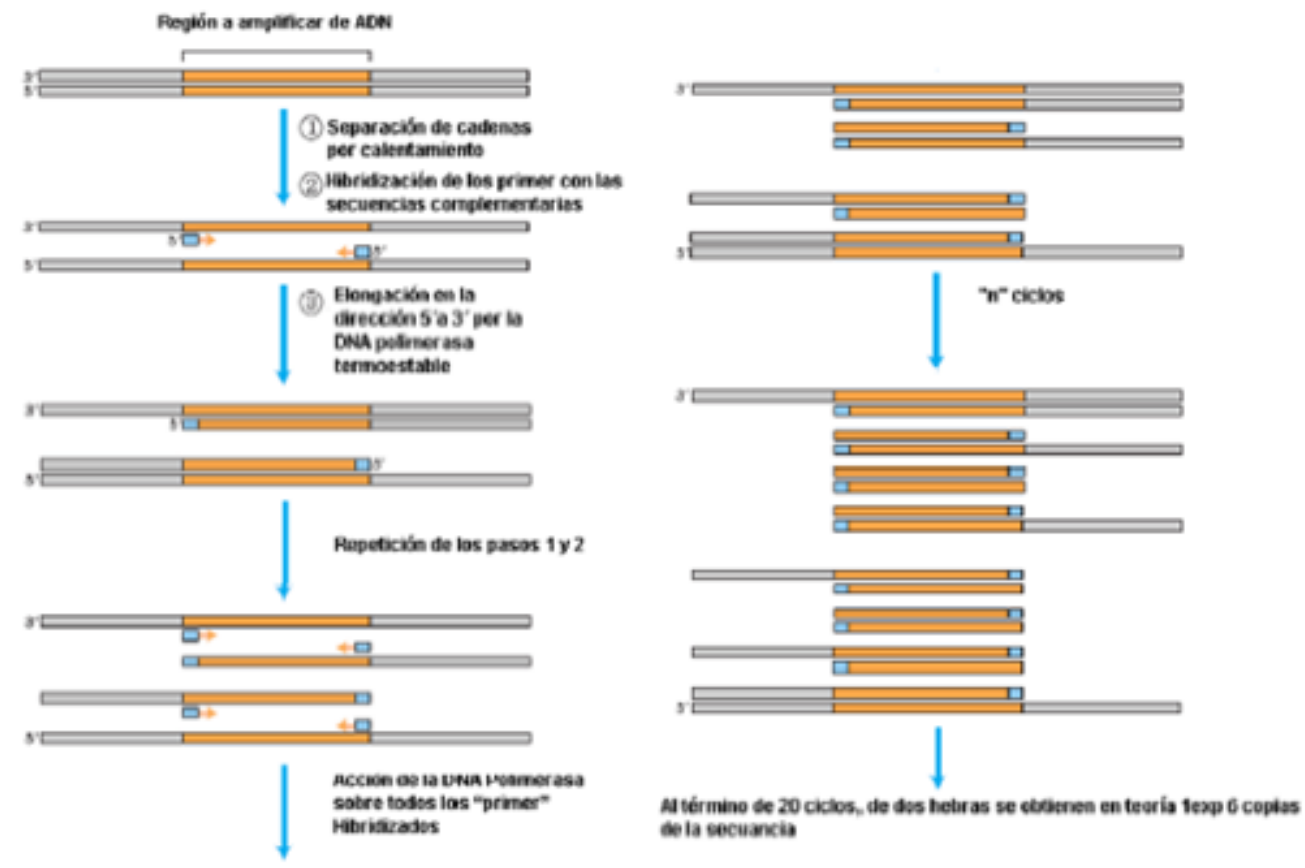

Figura 4.2. Esquema de la amplificación de una secuencia de DNA mediante la técnica de la Reacción en Cadena de la Polimerasa $(\mathrm{PCR})^{58}$

Con una modificación de esta técnica se logra introducir una mutación, ya sea eliminando, agregando o cambiando los codones que codifican para aminoácidos, además de la amplificación de una región o secuencia de DNA genómico.

En este trabajo sintetizamos 1 mutante natural de apoA-I hallada en pacientes con amiloidosis: Arg173Pro (R173P) ${ }^{29}$. El mismo fue construido por mutagénesis sitiodirigida sobre un cDNA de la proteína con la secuencia nativa, clonado en el vector de expresión pET-30, utilizando un kit de Quick Change (Stratagene, La Jolla, CA). Una mutación extra que fue previamente introducida genera una secuencia Asp-Pro entre los aminoácidos 2 y 3 de la apo A-I, la que es sensible al clivaje químico del péptido HisTag en el extremo N-terminal. De este modo se generó un sitio de corte susceptible a proteólisis a través de la incubación con ácido fórmico durante $5 \mathrm{~h} \mathrm{a} 60^{\circ} \mathrm{C}^{60}$. Los primers utilizados fueron:

- Para el mutante apoA-I Arg173Pro:

Forward: 5' GAGCTGCGCCAGCCCTTGGCCGCGCG 3'

Reverse: 5' CGCGCGGCCAAGGGCTGGCGCAGCTC 3' 

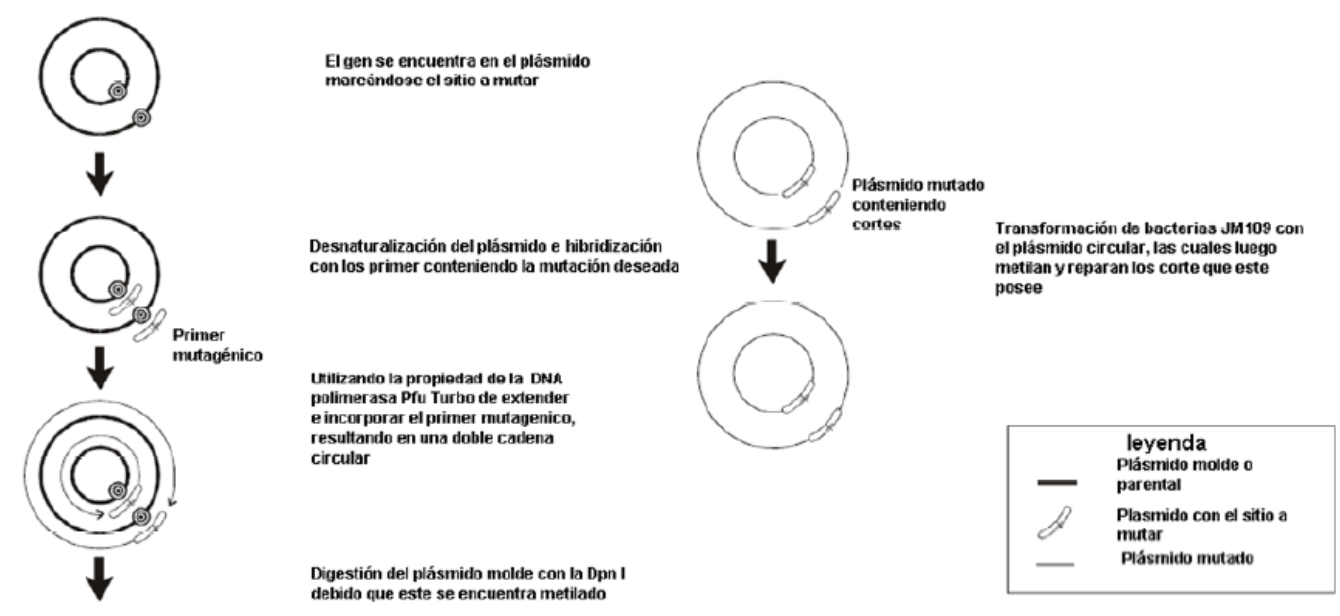

Figura 4.3: Esquema de PCR modificada en donde se logra la mutación de un gen en un sitio específico

El esquema general de esta etapa se representa en la figura 4.3. La PCR se realizó de la siguiente manera:

$\checkmark$ STAGE 1: $95^{\circ} \mathrm{c} 1$ minuto

$\checkmark$ STAGE $2: 95^{\circ} \mathrm{c} 1$ minuto, $62^{\circ} \mathrm{c} 1$ minuto, $72^{\circ} \mathrm{c} 13$ minutos (16 ciclos)

$\checkmark$ STAGE 3: $72^{\circ} \mathrm{C} 5$ minutos

Una vez realizadas las rondas de PCR, en presencia de las secuencias iniciadoras complementarias mencionadas, se digirió el producto con enzima de restricción DpnI que elimina el plásmido molde ó “template" y el producto de la digestión se transformó en bacterias competentes de clonación JM109, con el objetivo de expandir el plásmido para posterior extracción por lisis alcalina y así verificar por secuenciación la introducción de la mutación deseada. Las muestras se enviaron a secuenciar mediante métodos estándares y se analizaron con ayuda de programas clásicos (Gene-runner). Una vez verificada la secuencia, se transformaron células (BL21 (DE3)) con el plásmido conteniendo el inserto deseado dado que estas bacterias son de expresión, lo que las hace apropiadas para llevar a cabo la expresión de la proteína.

\section{Expresión y purificación}

Luego de que los plásmidos fueron introducidos en las bacterias BL21 y verificado que las bacterias se expresaron y purificaron, se realizó un plaqueo en medio LB-agar con antibiótico (kanamicina); se tomó una colonia y se creció en $5 \mathrm{ml}$ de medio líquido toda la noche $(\mathrm{ON})$, para después inocular $1 \mathrm{ml}$ de estas bacterias en un erlenmeyer con $500 \mathrm{ml}$ de medio líquido. El crecimiento se continuó hasta una densidad 
óptica (DO) de 0.6 a $600 \mathrm{~nm}$ para inducir a continuación la expresión con $0.4 \mu \mathrm{M}$ IPTG. Se dejó induciendo por el término de dos horas, se cosecharon las bacterias por centrifugación 10 minutos a $8000 \mathrm{rpm}$. La sobre expresión proteica se confirmó mediante SDS-PAGE (Figura 4.4 A).

Al pellet de bacterias se lo lisó incubando durante 4 horas con solución de guanidina $\mathrm{HCl}(\mathrm{Gnd}-\mathrm{HCl}) 6 \mathrm{M}, \mathrm{ClNa} 150 \mathrm{Mm}$, Tris $20 \mathrm{mM} \mathrm{pH} 8$, ya que una gran cantidad de proteína expresada se deposita en los cuerpos de inclusión. Se centrifugó nuevamente para eliminar membranas y restos celulares, el sobrenadante se dializó contra 2 litros de buffer Tris- $\mathrm{HCl} 20 \mathrm{Mm}, \mathrm{ClNa} 150 \mathrm{Mm} \mathrm{pH} \mathrm{8.} \mathrm{Al} \mathrm{término} \mathrm{de} \mathrm{la} \mathrm{diálisis}$ se centrifugó nuevamente para eliminar restos insolubles del medio acuoso, y el sobrenadante se purificó a través del pasaje por columnas de afinidad con níquel (GE Healthcare Bio-Sciences AB, Uppsala, Suecia. IMAC-Sepharose). Las proteínas recombinantes son adsorbidas a la matriz de la columna por afinidad con la cola de polihistidina, y, posteriormente fueron eluídas por competencia con buffer con Imidazol (50 $\mathrm{mM})$. Se recogieron las fracciones y a fin de confirmar la pureza se realizó una nueva corrida electroforética en geles de poliacrilamida en condiciones desnaturalizantes con SDS-PAGE, tiñendo con Coomasie-Blue para identificar la fracciones donde eluyó la proteína. (Figura 4.4 B)
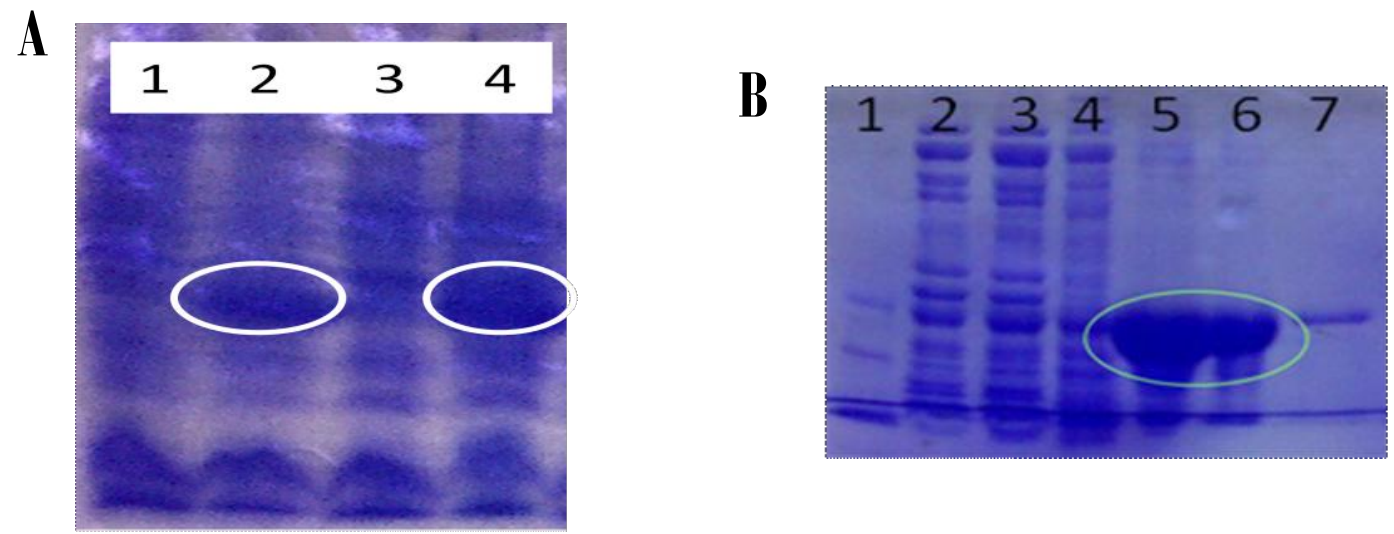

Figura 4.4 A) Chequeo de inducción de expresión en E. Coli BL21. Se confirmó la expresión mediante SDS-PAGE. Líneas 2 y 3 corresponden a R173P y El10K, respectivamente previo la inducción de un cultivo con IPTG. El círculo blanco señala la banda correspondiente al peso molecular de la proteína más la cola de poli-histidina (aprox. 42 klla), evidenciando la expresión de las cepas inducidas vs las no inducidas (líneas 1 y3 respectivamente); B) Chequeo de purificación de proteínas mediante SDS-PAGE. Línea 1 corresponde a estándar conteniendo apoA-I Wt (banda inferior) y apo Wt con cola de His (banda superior). Líneas 2 a 7 corresponden a distintas elusiones a través de la columna, mostrando fracciones de proteína pura (señaladas con el círculo) a partir de la fracción 4. 
En un paso posterior, la cola de poli histidina fue clivada por incubación durante 5 horas a $59^{\circ} \mathrm{C}$ con ácido fórmico al $45 \%$, el ácido fue luego dializado y la cola separada mediante un proceso similar por elusión en estas columnas, reconfirmando la obtención de una proteína pura de 28 kD mediante SDS-PAGE $^{60}$ (Figura 4.5)

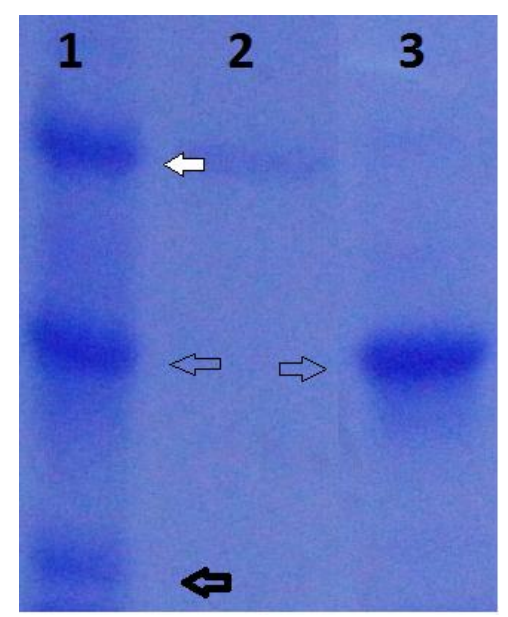

Figura 4.5: Chequeo de purificación de proteínas mediante SDS-PAGE. Línea 1 corresponde a estándar conteniendo apo Wt con cola de His (banda superior, flecha blanca), apo madura (llecha vacía bordes finos), y cola de histidina (banda inferior, flecha vacía de bordes gruesos); Línea 2 corresponde a la fracción de apo unida a la cola de His y la línea 3 muestra la apo purificada.

\section{Conservación de las proteínas y cuantificación}

Con el fin de asegurar la conformación proteica recientemente plegada, previo a cada experimento las proteínas fueron disueltas en $2 \sim \mathrm{M}$ de $\mathrm{GndHCl}$ y dializadas extensivamente frente a Tris- $\mathrm{HCl} 20 \mathrm{mM} \mathrm{pH} \mathrm{7,4.} \mathrm{El} \mathrm{contenido} \mathrm{de} \mathrm{proteína} \mathrm{se} \mathrm{cuantificó}$ por la técnica Bradford $^{61}$, o mediante la medición de la densidad óptica en un espectrofotómetro Bio-Rad (Hercules, CA), usando un coeficiente de extinción de $32.430 \mathrm{M}^{-1} \mathrm{~cm}^{-1}$ a $280 \mathrm{~nm}$.

\section{B. TÉCNICAS ELECTROFORÉTICAS}

Cuando una molécula cargada es sometida a un campo eléctrico, ésta migrará a una velocidad que dependerá del tamaño, carga neta, forma y viscosidad del medio en el cual se mueve $\mathrm{e}^{62}$. Por lo tanto establecidas las condiciones de $\mathrm{pH}$ y fuerza iónica, cada molécula migrará a una única posición dentro del campo eléctrico. En la separación de moléculas de ácidos nucleicos el soporte utilizado es un gel de agarosa, mientras que para la separación de proteínas el soporte utilizado es una matriz polimerizada de 
acrilamida y N,N'-metil-bis-(acrilamida) (PAGE) en buffer glicina usando como iniciador tetrametilenamida (TEMED) y como catalizador persulfato de amonio. Este tipo de geles es mecánicamente fuerte, termoestable y químicamente inerte. El efecto tamiz aumenta la resolución y puede graduarse fácilmente el tamaño del poro, modificando las cantidades de agente soporte.

\section{Geles de agarosa}

La electroforesis de geles de agarosa se utilizó en la separación de fragmento de DNA en base a su peso molecular y a su grado de empaquetamiento; los fragmentos más pequeños migran más rápido que los de mayor tamaño. El tamaño puede ser determinado por calibración del gel con estándares de peso molecular conocido y comparando las distancias que migran los fragmento desconocidos.

- Preparación del gel: se realizaron geles horizontales, con solución de agarosa al $0.8 \%$ en buffer TBE. Dado que la agarosa se disuelve en caliente, se preparó primero la suspensión de la misma y se la calentó en horno de microondas agitando cada 15 segundos hasta que no se observaron más "grumos" de agarosa. Una vez logrado una solución homogénea se la dejó enfriar hasta unos $60^{\circ} \mathrm{C}$ y se la volcó en la cama horizontal del gel, colocando el peine para formar los pocillos de siembra, dejando enfriar hasta que gelifique. Por último se colocó el gel en la cuba electroforética y se la cubrió con buffer TBE.

- Siembra de muestras: se sembraron 5 ul de las mismas (y se corrió a 100 voltios hasta que el frente haya recorrido aproximadamente el 80\% del tamaño del gel. Para observar la presencia de ácidos nucleicos se incubó el gel por 30 minutos en solución de bromuro de Etidio al 10\% en TBE, para luego observar las bandas por medio de luz UV de un trans iluminador.

Las soluciones utilizadas fueron:

$\checkmark$ Solución de TBE (Tris $50 \mathrm{mM}$ - Boro $50 \mathrm{mM}$ - EDTA $1 \mathrm{mM}$ ) pH 8

$\checkmark$ Buffer de siembra (6X: NaOH 300mM, 6 mM EDTA, $18 \%$ p/v ficoll, $0.15 \%$ p/v verde de Bromo cresol, y $0.25 \%$ p/v Xileno Cianol)

\section{Geles de Poliacrilamida}

Los geles PAGE fueron utilizados para la determinación de pureza y pesos moleculares de proteínas y/o complejos lipoproteicos; para esto se utilizaron básicamente dos tipos 
de procedimientos: uno en condiciones nativas y con gradiente de poliacrilamida, en donde cada proteína migra dependiendo de la relación carga/masa hasta que el tamaño del poro impide su migración; la otra variante es en condiciones desnaturalizantes con SDS (SDS-PAGE), en donde la matriz tiene una composición constante, pero todo el sistema posee un detergente como agente desnaturalizante; éste desestabiliza toda interacción no covalente de la proteínas combinándose en una relación estequiométrica (por cada 2 aminoácidos 1 de SDS), independizando la carga neta que tendría la proteína a ese $\mathrm{pH}$, y por lo tanto siendo la migración dependiente solamente del tamaño de la molécula.

Los protocolos de estos sistemas fueron:

- $\quad$ Sistema de gel nativo en gradiente para proteínas (PAGE):

El método utilizado fue el de Laemmli ${ }^{62}$. Consiste en un sistema vertical discontinuo que posee dos geles contiguos, pero distintos: el gel separador por debajo y el gel de siembra por encima, ambos distintos en fuerza iónica, $\mathrm{pH}$ y tamaño de poro. Esta discontinuidad sirve para concentrar grandes volúmenes de muestra en el gel de siembra, resultando en una mejor resolución final. El gel de siembra se preparó con una concentración final de $4 \% \mathrm{p} / \mathrm{v}$ de acrilamida, la cual se polimeriza resultando el tamaño de poro no limitante. El gel separador implica un gradiente lineal de concentración que va de $4 \%$ a $25 \% \mathrm{p} / \mathrm{v}$ en acrilamida. Las proteínas se detectaron coloreando con solución de Coomassie Blue, ó tinción de plata en caso de que la cantidad de proteína haya sido inferior a la detectada con la primera técnica (menor a $1 \mathrm{ug})^{63}$.

- $\quad$ Sistema de gel desnaturalizante (SDS-PAGE):

Posee como el anterior dos geles contiguos, uno separador y otro resolutivo diferenciándose en las condiciones de $\mathrm{pH}$, fuerza iónica y tamaño de poro, el primero posee la mismas condiciones que el nativo, excepto que posee el agente desnaturalizante SDS a una concentración de $0.1 \%$ p/v. El gel resolutivo consiste en un gel continuo de concentración constante, lo cual indica que el tamaño del poro es igual a lo largo del gel, este tamaño se logra variando la concentración final de acrilamida, y como el gel de siembra, posee SDS en una concentración de $0.1 \%$. La muestra es tratada con buffer muestra con SDS (0.1\%), se la hierve 3 minutos, y se corre el gel a 140 voltios. La tinción es similar que en caso anterior.

Las soluciones utilizadas son:

- Geles PAGE y SDS- PAGE

$\checkmark$ Acrilamida (40\% p/v)/Bis Acrilamida (0.8\%) 
$\checkmark$ Buffer de gel siembra: Tris-HCl 0.125M pH 6.8

$\checkmark$ Buffer de gel separador: Tris- $\mathrm{HCl} 0.375 \mathrm{M} \mathrm{pH} 8.8$

$\checkmark$ Iniciador: Persulfato de amonio $(10 \mathrm{mg} / 100 \mu \mathrm{l})$

$\checkmark$ Catalizador: TEMED

$\checkmark$ Buffer de desarrollo: Tris-Glicina 0.025 M- Tris 0.192 M Glicina. PH 8.3.

$\checkmark$ Colorante: Coomassie Blue g-250, $0.1 \%$, en ácido acético 10\%, metanol 40\%

$\checkmark$ Buffer muestra: Tris $0.062 \mathrm{M}$, glicerol $10 \%$, azul de bromo fenol $(0.05 \mathrm{mg} / \mathrm{ml})$, pH 6.8

Los SDS-PAGE poseen todas las soluciones SDS de concentración $0.1 \%$

\section{WESTERN BLOT}

Técnica analítica usada para detectar proteínas específicas en una muestra determinada. Mediante una electroforesis en gel se separan las proteínas, luego son transferidas a una membrana de nitrocelulosa o PVDF, en buffer de transferencia (Tris $48 \mathrm{mM}$, Glicina 39mM, Metanol 20\%). Esta transferencia se realizó a 100 volts durante 1 hora, en frío.

Revelado: Se incubó la membrana toda la noche a $4^{\circ} \mathrm{C}$ con solución de bloqueo ( $3 \mathrm{~g}$ de Leche descremada en $100 \mathrm{ml}$ de Buffer tris salino: 10mM Tris, $150 \mathrm{mM} \mathrm{ClNa}$ ); luego de 3 lavados de la membrana con tris salino, se incubó $2 \mathrm{~h}$ a temperatura ambiente con agitación suave con anticuerpo primario en dilución conveniente, luego tras 2 lavados con buffer salino se incubó 1 hora con anticuerpo secundario. Se realizaron 3 lavados con buffer Tris Salino.

Revelado: Soluciones a utilizar:

- SOLUCIÓN A:

$\checkmark$ Luminol 250mM

$\checkmark$ ÁC. P-cumárico $90 \mathrm{mM}$

$\checkmark$ Tris- $\mathrm{HCl} 1,5 \mathrm{mM} \mathrm{pH} 8.5$

- SOLUCIÓN B:

$\checkmark$ Tris-HCl 1,5 mM pH8,5

$\checkmark \mathrm{H}_{2} \mathrm{O}_{2} 30 \%$

Se incubó la membrana en la oscuridad con mezcla de partes iguales de la solución A y B preparada en el momento durante 1 minuto. Luego se colocó contra una placa radiográfica en un cassette cerrado herméticamente durante aproximadamente 20- 
30 minutos. Se retiró la placa, se la sumergió en revelador hasta visualizar las bandas, se lavó con agua y se colocó en solución fijadora unos minutos. Se retiró la placa radiográfica y se secó.

\section{Obtención de anticuerpos primarios anti apoA-I}

A fin de obtener anticuerpos policlonales anti-apoA-I se inyectaron 2 conejos con $1 \mathrm{ml}$ de solución $1 \mathrm{mg} / \mathrm{ml}$ de proteína apoA-I con relación 1:1 de Adyuvante de Freund completo. Se realizaron 5 inyecciones de $0,2 \mathrm{ml}$ en distintos puntos de los flancos de cada conejo. Se criaron los conejos durante un mes. Posteriormente se realizó el mismo procedimiento pero con $1 \mathrm{ml}$ de solución de proteína $0,5 \mathrm{mg} / \mathrm{ml}$ en adyuvante de Freund incompleto (relación 1:1). A los 15 días se desangraron los conejos por punción cardíaca. Se dejó coagular la sangre (4 horas en estufa a $\left.37^{\circ} \mathrm{C}\right)$. Se centrifugó a $5000 \mathrm{rpm}$ durante 10 minutos para extraer la mayor cantidad de suero del coágulo. Se descartó el precipitado. El sobrenadante (suero) se sometió a una precipitación con solución saturada de $\mathrm{SO}_{4}\left(\mathrm{NH}_{4}\right)_{2}$ : Se agregó la mitad del volumen total de suero de sulfato, se centrifugó 30 minutos a $5000 \mathrm{rpm}$. Se descartó el sobrenadante (fracción 1), posteriormente se resuspendió el pellet en la mitad de volumen de agua destilada, se agregó la mitad de ese volumen de sulfato, se repitió la centrifugación, y así sucesivamente. El procedimiento se repitió 3 veces, considerando que en la tercera fracción precipita la mayor cantidad de Inmunoglobulinas G. Se realizó un dot-blot de las fracciones obtenidas para corroborar la eficiencia de la detección de apoA-I (Figura 4.6) 


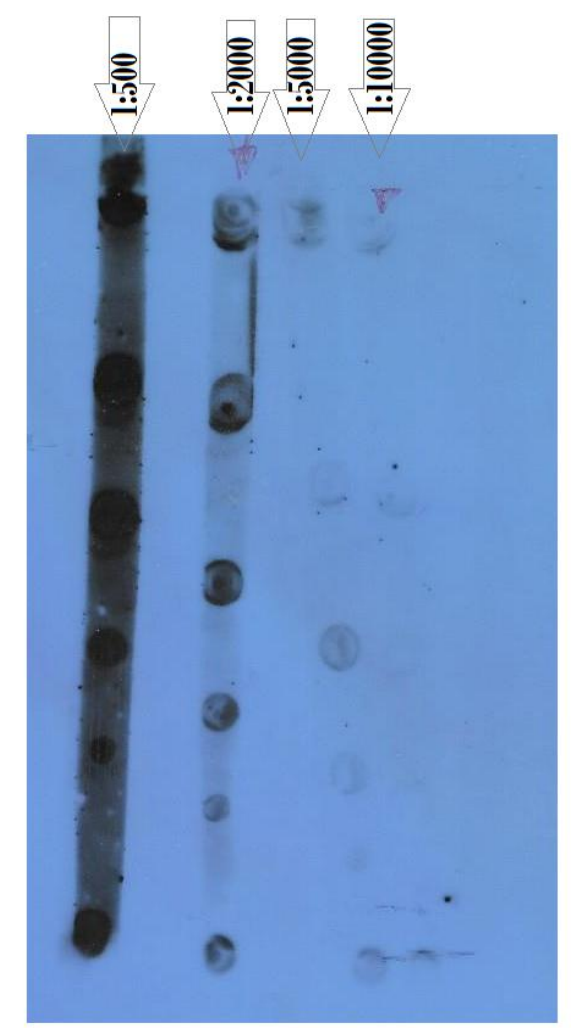

Figura 4.6: Dot-blot de apoA-I Arg173Pro y Wt. En cada tira se sembraron 2 uL de arriba hacia debajo de: 1- Wt lmg, 2-Wt $0.8 \mathrm{mg} / \mathrm{ml}, 3-\mathbb{W t} 0.6 \mathrm{mg} / \mathrm{ml}, 4-\mathbb{W t} 0.4 \mathrm{mg} / \mathrm{ml}, 5-\mathbb{W t} 0.2 \mathrm{mg} / \mathrm{ml}, 6$ - Arg 173 Pro $1.0 \mathrm{mg} / \mathrm{ml}$. Los recuadros con flechas indican las respectivas diluciones del anticuerpo primario anti apo A-I. En todos la dilución de anticuerpo secundario utilizada fue de 1:5000.

\section{Purificación del anticuerpo en columnas Hi-Trap}

Las columnas Hi-Trap se adquirieron comercialmente (GE- Health care). Estas columnas para cromatografía de afinidad, tienen una matriz pre-envasada de grupos $\mathrm{NH}$ activada a la cual se unen covalentemente proteínas para purificar el anticuerpo. En nuestro caso realizamos la unión de la proteína apoA-I Wt a la columna a fin de poder purificar el anticuerpo obtenido por inmunización del conejo. Esto lo realizamos como indicaba el protocolo. Luego procedimos a la purificación del anticuerpo: La fracción 3 de precipitación con $\mathrm{SO}_{4}\left(\mathrm{NH}_{4}\right)_{2}$ se dializó contra buffer Tris $75 \mathrm{mM} \mathrm{pH}$ 8; equilibramos la columna con buffer binding (Tris $75 \mathrm{mM} \mathrm{pH} \mathrm{8),} \mathrm{eluimos} \mathrm{la} \mathrm{fracción} \mathrm{con} \mathrm{anticuerpo,}$ lavamos con buffer binding nuevamente para separar lo inespecíficamente unido, luego eluimos el anticuerpo con buffer $100 \mathrm{mM}$ glicina, 0,5 M CINa pH 2,7, aquí observamos un pico de elusión a $280 \mathrm{~nm}$. Por último, equilibramos nuevamente la columna. Realizamos un western-blot para confirmar la presencia del anticuerpo en las fracciones de elusión (Figura 4.7) 


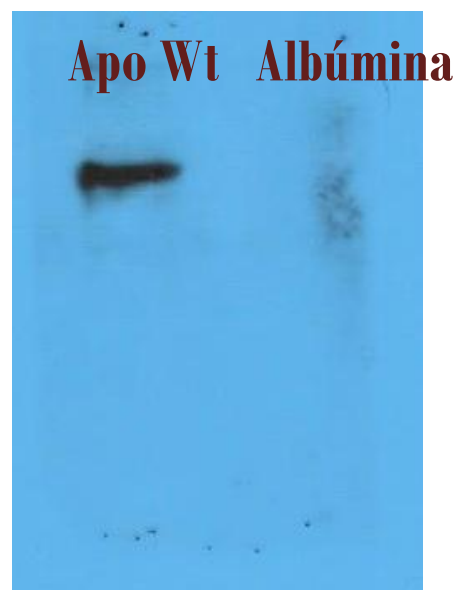

Figura 4.7: western-Blot realizado para confirmar la purificación del anticuerpo anti apoA-I. Título de anticuerpo primario usado 1:90000. El título de anticuerpo secundario Anti IgG de conejo utilizado fue de 1:3000. Como control negativo se usó Albúmina.

\section{TÉCNICAS DE FLUORESCENCIA ${ }^{64}$}

\section{Fundamentos de la técnica}

La luminiscencia es la emisión de fotones desde estados electrónicamente excitados. La fluorescencia es la emisión que resulta del regreso de un electrón apareado a su nivel basal. Las sustancias que poseen capacidad fluorescente, poseen por lo general electrones deslocalizados, típicamente en dobles enlaces conjugados. Lo antes dicho está esquematizado en los diagramas de A. Jablonski (Figura 4.8)

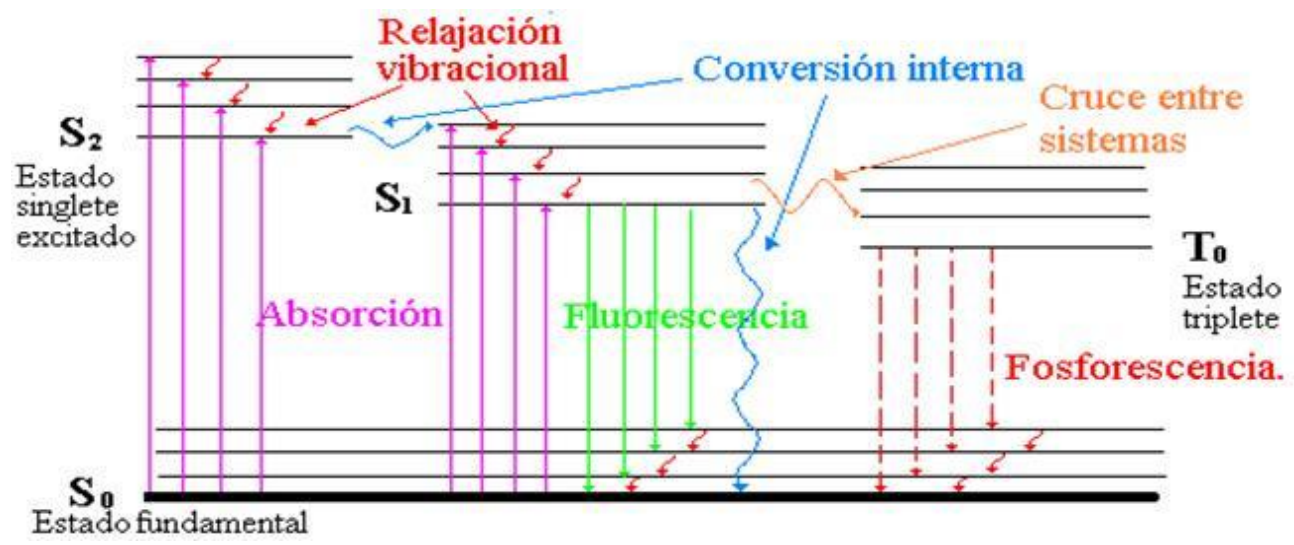

Figura 4.8 Los estados basales están representados por S0, mientras que los primeros estados electrónicos superiores son S1 y S2; en los fluoróforos pueden existir diferentes estados vibracionales determinados por 1, 2, 3, etc. La absorción está representada en forma vertical ascendente, ya que ilustra a la absorción como un proceso instantáneo, dicho proceso ocurre en el orden de $10^{-15} \mathrm{~s}$, que es un tiempo muy corto para que se produzca un desplazamiento nuclear significativo. 
Los niveles electrónicos basal, primer y segundo están representados por $\mathrm{S}_{0}, \mathrm{~S}_{1} \mathrm{y}$ $\mathrm{S}_{2}$, respectivamente. En cada uno de estos niveles energéticos los fluoróforos pueden existir en distintos niveles vibracionales, mostrados como 0, 1, 2, etc. En este diagrama se excluyen un número de interacciones que pueden ocurrir en el estado excitado, como por ejemplo apagado, transferencia de energía e interacción con solventes. Un fluoróforo puede ser excitado a niveles vibracionales superiores de $S_{1}$ o también a $S_{2}$. Salvo por excepciones, las moléculas suelen relajarse rápidamente a los niveles vibracionales inferiores de $\mathrm{S}_{1}$. Este proceso se llama conversión interna y ocurre en $10^{-}$ 12 segundos. Este tiempo relativamente corto en relación a la vida media de la fluorescencia (del orden de $10^{-8} \mathrm{~s}$ ), hace que la conversión interna ocurra casi completamente previa a la emisión. Así la emisión de fluorescencia ocurre desde estados excitados térmicamente equilibrados.

Los espectros de fluorescencia son presentados como espectros de emisión, en los cuales se determina el cambio de intensidad de fluorescencia en función de la longitud de onda, esta emisión dependerá de la estructura química del fluoróforo y del solvente en que se encuentre disuelto. Así tanto la intensidad como el corrimiento del máximo de emisión espectral dan información importante. La primera depende de la concentración de fluoróforo, de la interacción del mismo con su entorno, de la transferencia de energía con la misma especie o con otra, del apagado por otra especie, etc. Todo esto determinará el rendimiento cuántico, o sea la relación entre fotones absorbidos versus los emitidos. El segundo proceso es llamado corrimiento de Stokes. Excepto para átomos en fase vapor, de la observación del diagrama de Jablonski se hace evidente que la energía de emisión es típicamente menor que la de absorción, y por lo tanto la fluorescencia ocurre a mayores longitudes de onda que la excitación. Los fluoróforos pueden presentar además, corrimientos adicionales debido a la relajación de los estados excitados ocasionados por solventes polares, ó sufrir reacciones químicas durante el estado excitado.

A fin de estudiar estructura proteica puede utilizarse fluoróforos sintéticos (fluoresceína, Bis-ANS, etc.), ó utilizar la capacidad de fluorescencia intrínseca, la que se origina de los aminoácidos aromáticos Tyr, Trp y Phe. El grupo indol del Trp es el que predomina cuando las proteínas absorben y emiten luz en la región del Ultravioleta del espectro. La Tyr tiene una intensidad de emisión similar a la del Trp, pero su máximo de emisión está dado en longitudes de onda menores que la de éste (Figura 4.9) y su fluorescencia puede ser modificada por interacciones con péptidos o aminoácidos 
como el Trp, además la misma aumenta en proteínas desnaturalizadas, debido a cambios en el pKa del fenol que favorecerían el estado excitado. La fluorescencia de la Phe adquiere importancia cuando en proteínas no existe residuos de Trp o de Tyr, cosa que raramente ocurre. La emisión del Trp es altamente sensible al ambiente que lo rodea, sufriendo un corrimiento hacia longitudes de onda mayores (hacia el rojo del espectro) cuando el medio al que se expone este residuo es acuoso. A fin de facilitar la interpretación de la influencia del medio en el que una proteína se encuentra sobre su estructura, se puede definir la longitud de onda (en $295 \mathrm{~nm}$ ) a fin de excitar casi exclusivamente a los residuos Trp (Figura 4.9).

La fluorescencia del Trp puede ser apagada por diferentes grupos, como ser I- , acrilamida, entre otros
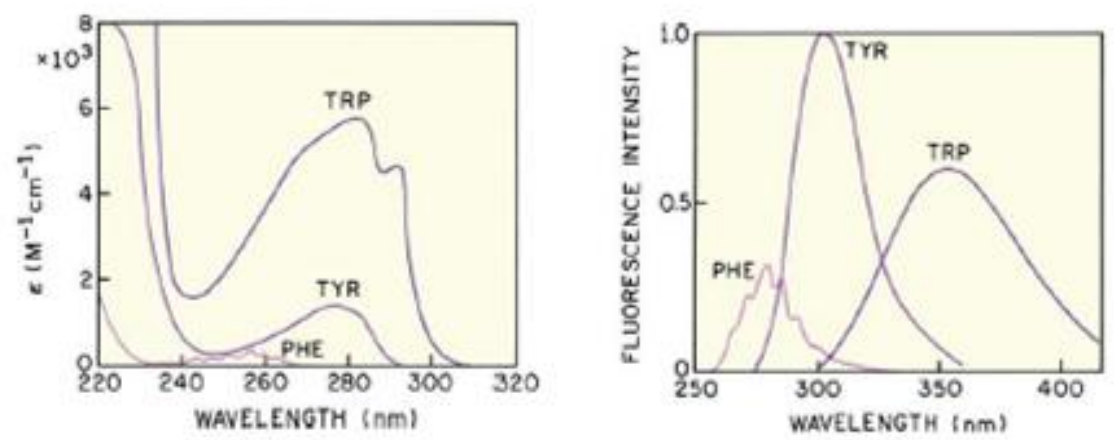

Figura 4.9: Espectros de absorción y de emisión de los aminoácidos fluorescentes en Agua a pH $7^{64}$.

\section{Desnaturalización química de la proteína mediada por Gnd-HCl}

La Gnd-HCl es un agente caotrópico que induce desnaturalización proteica, lo que provoca la exposición al medio acuoso de residuos aromáticos, como el Trp, que en condiciones nativas se encuentran en un entorno hidrofóbico como consecuencia del plegamiento terciario de la proteína.

La concentración de guanidina requerida para inducir el desplegamiento depende de la estabilidad conformacional de la misma, y por lo tanto el seguimiento del corrimiento de la fluorescencia del Trp en función de la concentración de guanidina permite el cálculo de la energía libre de desnaturalización. La apoA-I Wt y Arg173Pro (a $0,1 \mathrm{mg} / \mathrm{ml})$ se diluyeron en buffer citrato-fosfato Mcilvaine $\left(\mathrm{Na}_{2} \mathrm{HPO}_{4} 0,2 \mathrm{M}\right.$; ácido 
cítrico $0,1 \mathrm{M})^{65}$, ya sea a $\mathrm{pH} 7,4$ o 5,0 , y se incubaron con concentraciones crecientes de Gnd-HCl. Se registró el espectro de emisión de fluorescencia intrínseca (correspondiente a la señal promedio a partir de cuatro residuos de Trp de origen natural en posiciones 8, 50, 72 y 108 en la secuencia primaria de la proteína nativa) en un espectrofluorómetro SLM4800, actualizado por Olis (ISS Inc., Champaign, IL). La longitud de onda de excitación fue $295 \mathrm{~nm}$ y la emisión se registró entre 310 y 420nm. Luego se calculó el centro de masa del espectro de fluorescencia a cada concentración de Gnd-HCl.

La variación de energía libre $\Delta \mathrm{G}$ en ausencia de desnaturalizante $\Delta \mathrm{G}_{0}$ fue obtenido de los valores espectrales, asumiendo un proceso en dos estados (nativo y desnaturalizado). La dependencia de $\Delta \mathrm{G}$ con la concentración de $\mathrm{GndHCl}$ puede ser deducida como:

$$
\Delta G=\Delta G^{0}+m[G n d H C l](1)
$$

El parámetro $\mathrm{m}$ fue considerado como proporcional a la exposición de la superficie hidrofóbica en función de la desnaturalización. En términos de la fracción de proteína desplegada $\alpha$ g a cada [GndHCl], la ecuación (1) puede ser expresada como:

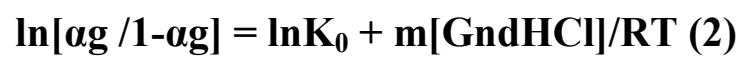

Donde $\mathrm{K}_{0}$ es la constante de equilibrio en ausencia de $\mathrm{GndHCl}$, $\mathrm{R}$ es la constante de gases y $\mathrm{T}$ es la temperatura de trabajo $\left(298^{\circ} \mathrm{K}\right)$. Del gráfico lineal de $\ln [\alpha \mathrm{g} / 1-\alpha \mathrm{g}]$ vs [GndHCl], es posible obtener $\mathrm{K}_{0}$ de la ordenada al origen, y de allí $\Delta \mathrm{G}_{0}$ como:

$$
\Delta G_{0}=-R T \ln K_{0}(3)
$$

\section{Apagado (Quenching) con acrilamida}

El fenómeno de quenching de la fluorescencia se refiere a los procesos que provocan una disminución en la intensidad de emisión fluorescente de una sustancia dada.

En este trabajo se analizó el quenching dinámico entre el Trp de las proteínas y acrilamida. Dado que la acrilamida es soluble en medio acuoso, la efectividad del quenching es muy utilizada para analizar el grado de exposición que presentan estos aminoácidos al solvente en las proteínas. Por ende, aquellos Trp ubicados en entornos hidrofóbicas serán menos accesibles a las moléculas de acrilamida y, por consiguiente, afectados con una menor eficiencia que aquellos triptófanos expuestos al medio 
acuoso $^{64}$. La exposición a disolventes de residuos de Trp fue determinada diluyendo las proteínas a una concentración final de $0,1 \mathrm{mg} / \mathrm{ml}$, y el quenching se determinó adquiriendo los espectros de emisión de apoA-I en presencia de concentraciones crecientes de acrilamida $(0-0,4 \mathrm{M})^{43}$.

El quenching dinámico ${ }^{66}$ puede representarse, esquemáticamente, como una transferencia de energía entre una especie excitada $\left(M^{*}\right)$ y una especie quencher $(Q)$ :

$$
M *+Q \rightarrow M+Q *
$$

Este proceso se describe por la ecuación de Stern-Volmer:

$$
\frac{F_{0}}{F}=1+K_{S v} \times[Q]
$$

Donde $\mathrm{F}_{0}$ y $\mathrm{F}$ son las intensidades de emisión fluorescente en ausencia y presencia del quencher, respectivamente, a una concentración del quencher [Q], y Ksv es la constante de Stern-Volmer.

\section{Titulación con Bis-ANS}

La sonda Bis-ANS es una molécula fluorescente sensible al ambiente cuyo rendimiento cuántico es muy bajo en solución acuosa, pero aumenta fuertemente cuando se une a superficies hidrofóbicas en las proteínas. Esta unión es especialmente eficiente en proteínas parcialmente desplegadas ${ }^{67}$.

La presencia de dominios hidrófobos expuestos en la estructura nativa de las variantes de apoA-I se evaluó por titulación con Bis-ANS ${ }^{68,69}$. Pequeñas alícuotas de Bis-ANS (de una solución madre concentrada en metanol) se añadieron a $0,1 \mathrm{mg} / \mathrm{ml} \mathrm{de}$ las variantes apoA-I a $25^{\circ} \mathrm{C}$ y los espectros de emisión de fluorescencia se adquirieron entre 450-550 nm con excitación ajustada a $395 \mathrm{~nm}$. La concentración residual de metanol se mantuvo a un mínimo con el fin de evitar artefactos estructurales debido a los efectos del solvente.

\section{v. Dicroísmo circular (CD)}

La técnica de CD ha sido ampliamente utilizada para investigar aspectos de la conformación de péptidos y proteínas ${ }^{7070}$. Para que un compuesto presente señal dicroica debe ser (o contener) un cromóforo quiral, o bien, si no fuera así, por 
interacción con grupos vecinos el cromóforo aquiral deberá adoptar una disposición o ubicarse en un ambiente químico que induzca asimetría. Fundamentalmente, CD se utiliza para (i) estimar el contenido global de estructura secundaria, (ii) detectar cambios conformacionales, y (iii) medir interacciones de ligandos (pequeñas moléculas o aún macromoléculas) o fases organizadas (por ejemplo, micelas o bicapas lipídicas) con los polipéptidos. Para la medida de CD resulta importante distinguir dos regiones espectrales. La zona del ultravioleta lejano (UVL) (aprox. 180-250 nm) y la zona del ultravioleta cercano (aprox. 250-340 nm). El espectro de CD en la región UVL informa sobre el contenido global de estructura secundaria. La interacción entre los planos representados por los enlaces peptídicos dependerá de su disposición relativa, que será diferente (y quiral) de acuerdo con el tipo de estructura secundaria que adopte la cadena, por ejemplo el sentido derecho de la hélice $\alpha$ o la casi completa inversión de los planos en una hebra ß. Este hecho da origen a espectros diferentes de CD (Figura 4.10).

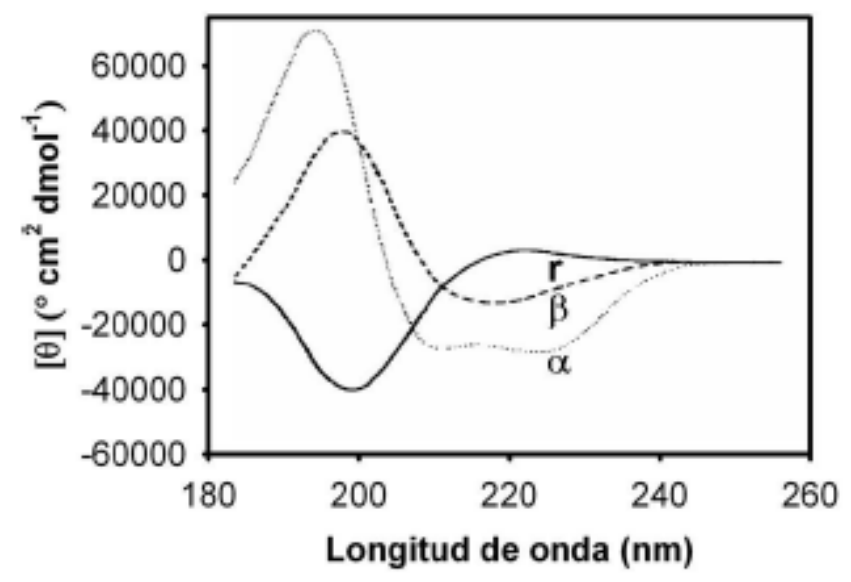

Figura 4.10: Espectros típicos para las estructuras secundarias $\alpha$ y ß. También se muestra un espectro random coil $^{66}$.

Los espectros se registraron sobre disoluciones de proteínas a $0,1 \mathrm{mg} / \mathrm{ml}$ mantenidas en buffer McIlvaine a una concentración mínima para evitar la interferencia de alta concentración de sal y ruido excesivo. Para la medición se utilizó un espectropolarímetro Jasco J-810 (IQUIFIB, Facultad de Farmacia y Bioquímica de la UBA). Los datos en el UV lejano (200-250 nm) fueron colectados utilizando una cubeta de $1 \mathrm{~mm}$ de paso óptico. La velocidad de escaneo fue de $20 \mathrm{~nm} /$ minuto con una constante de 1 segundo de tiempo tanto para la variante Wt como para Arg173Pro. Cada espectro se midió al menos tres veces y los datos se promediaron para reducir al mínimo 
el ruido. Se calculó la elipticidad molar ${ }^{71}$, utilizando un valor de peso medio por residuo de 115,5 y 115,2 para las proteínas Wt y Arg173Pro, respectivamente.

\section{Transferencia de energía de resonancia de fluorescencia de Trp a Bis-ANS}

La transferencia de energía por resonancia de fluorescencia (FRET) es una interacción dependiente de la distancia entre los estados excitados electrónicos de dos moléculas fluorescentes, en la que se transfiere la (excitación) energía de emisión fluorescente de un donante (D) a una molécula aceptora (A), (sin emisión de un fotón) la que es empleada para su excitación. La eficiencia de la transferencia de energía (E) se puede calcular por la ecuación:

$$
\mathrm{E}=\frac{R o^{6}}{\left(R o^{6}+R d^{6}\right)}
$$

Donde $\mathrm{R}_{\mathrm{o}}$ representa el radio de Förster, es decir, la distancia cuando la transferencia es de 50\% de eficiencia (para el par donor-aceptor Trp-BisANS se calcula una distancia de $26,3 \AA)^{72}$, y $\mathrm{R}_{\mathrm{d}}$ es la distancia real entre donor y aceptor. Cuando el donor y aceptor son químicamente diferentes, FRET es típicamente medido utilizando la intensidad de fluorescencia relativa del donor en presencia $\left(F_{D A}\right)$ y en ausencia $\left(F_{D}\right)$ del aceptor ${ }^{64}$ :

$$
E=\frac{1-F_{D A}}{F_{D}}
$$

Con el fin de determinar la transferencia de energía de fluorescencia, de Trp (donor) a Bis-ANS (aceptor), 0,1 mg/ml (3,6 $\mu \mathrm{M})$ de la variante de apoA-I Arg173Pro, se incubó ya sea a pH 7,4 ó 5,0 y se registró la intensidad de emisión al Trp, con excitación a $295 \mathrm{~nm}$ y el espectro de emisión captada entre 300 y $550 \mathrm{~nm}$. A continuación, el mismo espectro se midió después de la adición de 1,6 $\mu \mathrm{M}$ de Bis-ANS . Excitación directo del Bis-ANS se registró a 395 nm. El FRET se calculó registrando la intensidad de emisión en el máximo del Trp en presencia y ausencia del Bis-ANS .

\section{E. DETECCIÓN DE AGREGADOS DE PROTEÍNAS}

La formación de agregados tipo amiloide puede ser inferida mediante unión a la

sonda fluorescente tioflavina $\mathrm{T}$ (ThT), la cual sugiere formación de estructuras de tipo amiloide, con mayor afinidad por agregados fibrilares pero también es sensible a 
estructuras oligoméricas, protofibrilares o $\operatorname{amorfas}^{73}$. Las variantes de apoA-I (0,2 $\mathrm{mg} / \mathrm{ml}$ ) se incubaron a diferentes valores de $\mathrm{pH}$. Después de 48 horas a $37^{\circ} \mathrm{C}$, se añadió ThT a una relación molar 1: 1 y se midió la intensidad de fluorescencia en un lector de microplacas Beckman Coulter DTX 880 (Beckman, CA), usando filtros de excitación y emisión centrada a $430 \mathrm{~nm}$ y $480 \mathrm{~nm}$, respectivamente. También se detectó dispersión de la luz con el espectrofluorómetro, estableciendo ambas longitudes de onda de excitación y emisión a $350 \mathrm{~nm}$.

\section{F. ENSAYO DE ACLARAMIENTO DE DMPC (DI MIRISTOIL FOSFATIDIL COLINA)}

Los liposomas multilamelares (MLV) se prepararon a partir de una solución madre de DMPC en cloroformo. Los lípidos se secaron en atmósfera de N2 y se resuspendieron en buffer Tris $20 \mathrm{mM} \mathrm{pH} \mathrm{7,4}$ por exhaustiva agitación en vórtex a $37^{\circ} \mathrm{C}^{74}$. Las proteínas, a una concentración final de $7 \mu \mathrm{M}$ en el mismo buffer se incubaron a la temperatura de transición de la DMPC $\left(24^{\circ} \mathrm{C}\right)$ con MLV de DMPC, en una relación molar lípido: proteína de 40:1 y se monitoreó la absorbancia por 90 minutos en lector de microplacas, utilizando un filtro de $350 \mathrm{~nm}$. Los productos finales después de 1 y 2 horas de incubación se analizaron por electroforesis nativa en gradiente de poliacrilamida (PAGGE).

\section{G. LA UNIÓN DE LIGANDOS A APOA-I VARIANTES}

Los glucosaminoglucanos (GAGs) son polímeros de disacáridos presentes en la mayoría de los tejidos. Hay abundante evidencia de que están implicados en la formación de depósitos amiloides que se encuentran en una variedad de enfermedades humanas $^{75,76}$. A fin de analizar la influencia de los GAGs en la retención de apoA-I y sus variantes en el microentorno, se utilizó heparina, heteropolisacárido sulfatado que puede ser constituyente de la matriz extracelular. La unión de proteína a heparina se ensayó mediante la incubación de $0,2 \mathrm{mg} / \mathrm{ml}$ de proteína con heparina en una relación molar 2: 1 de heparina: proteína durante 48 horas a $37^{\circ} \mathrm{C}$. Con el fin de confirmar si la unión a heparina resulta en la formación de complejos de alto peso molecular, las mezclas incubadas se analizaron por PAGGE. Además se midió fluorescencia asociada a ThT de las muestras incubadas con heparina, tanto a pH 5 como 7,4. 
Se ha sugerido además previamente que la alteración en la composición lipídica en el microambiente podría inducir un cambio conformacional de apoA-I o péptidos derivados del domínio terminal ${ }^{44,45}$. La presencia de lípidos cargados negativamente en la membrana plasmática es una característica común asociada a aterosclerosis u otros eventos inflamatorias crónicos locales que inducen apoptosis. En este trabajo testeamos la hipótesis de que éstos u otros componentes de la membrana celular pudieran interactuar y/o influir en el plegamiento anómalo de esta proteína. El SDS es una moléculas anfipática que, dada su cabeza polar negativa (sulfato) y su cola hidrocarbonada apolar (dodecilo) fue sugerido como modelo de lípido de membrana. Las proteínas Wt y Arg173Pro (0,2 mg/ml) se incubaron con SDS 0,2 mM (ya sea a un $\mathrm{pH}$ de 7,4 o 5.0 ) durante 48 horas a $37^{\circ} \mathrm{C}$. La formación de complejos se detectó mediante la unión a ThT como se describió arriba.

\section{H. TÉCNICAS MICROSCÓPICAS}

\section{$\underline{\mathrm{AFM}}$}

La resolución de la microscopia óptica está determinada por la difracción de la luz, y típicamente es del orden de $200 \mathrm{~nm}$. En cambio los microscopios de barrido por sonda (del acrónimo en inglés SPM) se basan en tocar o detectar la muestra más que observarla, por lo que detectan cambios en alguna magnitud cuando la punta (probe) recorre la superficie, pudiéndose obtener imágenes tridimensionales a tiempo real. ${ }^{77}$

La mayor resolución de esta microscopia se basa en la alta dependencia de la interacción con la distancia que ocurre entre la punta y la muestra, por ejemplo corriente túnel o fuerzas de Van der Waals, y una sonda local o punta aguda exactamente posicionada en la superficie gracias a la precisión de elementos piezo eléctricos.

Dependiendo de la interacción punta- muestra se han desarrollado distintos tipos de microscopias de SPM, las cuales las más típicas se puede resumir en:

STM: Scanning Tunneling Microscopy

AFM: Atomic Force Microscopy

LFM: Lateral Force Microscopy

MFM: Magnetic Force Microscopy

EFM: Electrostatic Force Microscopy

SCM: Scanning Capacitance Microscopy

En este trabajo se utilizó microscopía de fuerza atómica (AFM) para caracterizar la conformación de la variante utilizada ante distintas condiciones. Los elementos básicos de este microscopio son los siguientes: (Figura 4.11) 


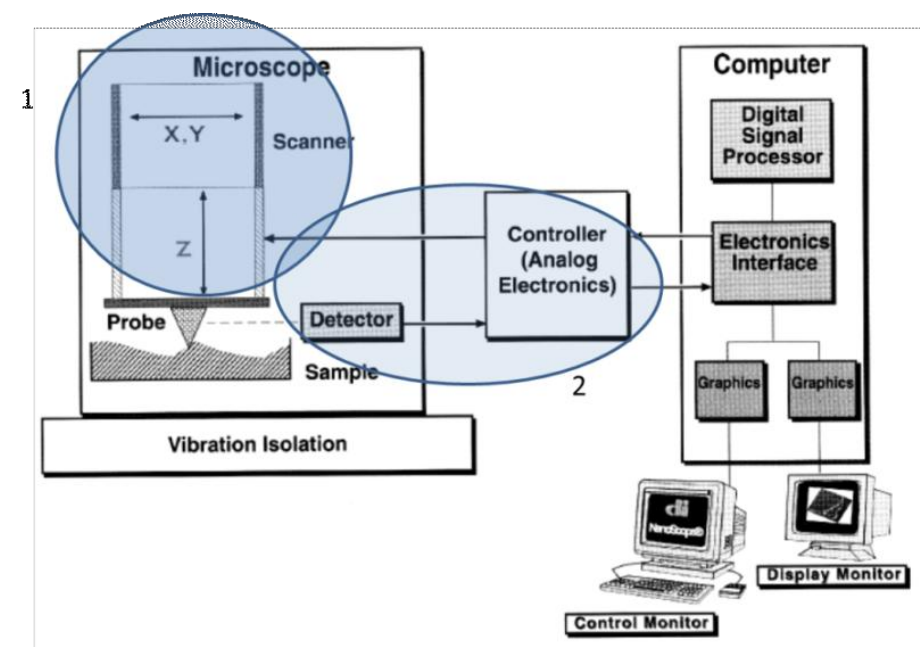

Figura 4.11: Elementos básicos de un AFI.

El elemento encargado de posicionar exactamente la punta respecto a la muestra es el scanner o barredor piezoeléctrico que cambia sus dimensiones en respuesta a un voltaje aplicado V.

Para lograr reconstruir la imagen tridimensional, el mismo recorre la superficie en las coordenadas $X$ e $Y$ a determinada velocidad (Figura 4.12 A), y "sensa" en cada punto de la superficie la interacción gracias al detector. El sistema de retroalimentación modifica y registra la posición en "Z" para mantener los parámetros interacción constantes, de acuerdo a los parámetros previamente definidos (Figura 4.12 B).

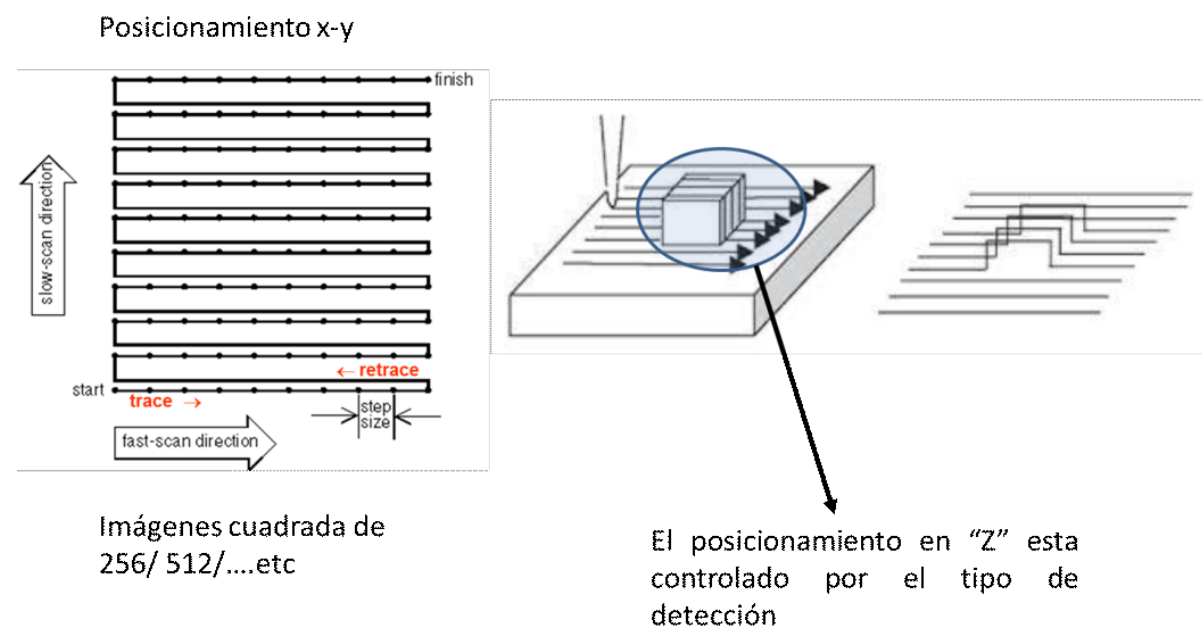

Figura 4.12: A) Esquema de posicionamiento $X-Y$. B)Posicionamiento en " $Z$ ".

En los microscopios de fuerzas atómicas, la sonda es una punta aguda sostenida en una viga o cantiléver, que a su vez está sostenida en una oblea o porta cantiléver; el modo de 
determinar la interacción es midiendo la deflexión de esta viga a medida que recorre la superficie, utilizándose para esto el cambio de reflexión de un AZ de laser que incide sobre la misma $^{78}$ (Figura 4.13)

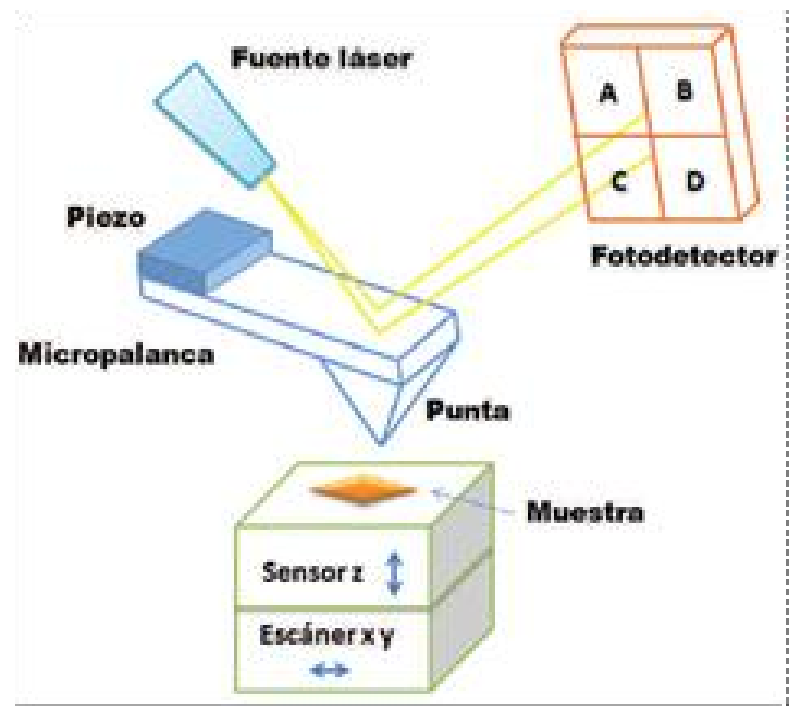

Figura 4.13: Componentes de un AFI. ${ }^{78}$

Cuando se acerca la punta a la superficie, ésta detecta diferentes interacciones de acuerdo a la distancia, como se muestra en la figura 4.14

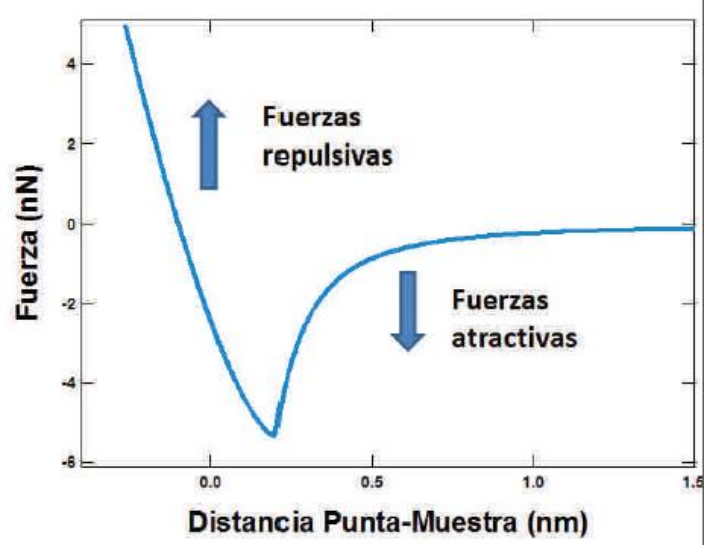

Figura 4.14: Curva típica Fueza-Distancia. ${ }^{78}$

De acuerdo a qué tipo de fuerzas se determinan (repulsivas o atractivas) son lo diferentes modos básicos de las microscopías de AFM.

Si la sonda siente fuerzas repulsivas, el modo de esta microscopía es Contacto, en donde la misma siempre toca la muestra. Si la sonda siente las fuerzas Atractivas, el modo es no contacto, en donde la punta no toca a la muestra. Si la punta sensa o se mueve entre la zona de contacto (fuerzas repulsivas) y de no contacto (fuerzas 
atractivas), el modo es intermitente o más conocido como tapping mode, en donde la punta toca intermitentemente a la muestra.

El primero de los modos tiene alta resolución pero no es adecuado para muestras biológicas ya que suele dañarlas. El segundo de los modos no tiene buena resolución lateral y es muy dependiente del tipo de muestra, mientras que el último es el más ampliamente utilizado en muestras biológicas, por lo que fue el utilizado en esta tesis para determinación de diferentes estructuras. La variante Arg173Pro se incubó a 0,5 $\mathrm{mg} / \mathrm{ml} \mathrm{y} \mathrm{pH} 7,4$ durante 24 horas a $37^{\circ} \mathrm{C}$ en ausencia o en presencia de heparina, posteriormente las muestras fueron lavadas con agua pura para eliminar las sales y se secaron con $\mathrm{N}_{2}{ }^{41}$.

Todas las imágenes se obtuvieron en condiciones ambientales usando un Vmultimodo Nanoscope (Veeco, Santa Barbara, CA) en modo tapping. La sonda utilizada fue Nano Word dotada con Nitruro de Silicio, cuyas características fueron: frecuencia de resonancia del cantilever: $258 \mathrm{kHz}$, constante de fuerza de $42 \mathrm{~N} / \mathrm{m}$; radio nominal de la punta $5-10 \mathrm{~nm}$. La velocidad de barrido fue de 1-1,5 Hz.

\section{INTERACCIÓN DE APO A-I CON POLÍMEROS SINTÉTICOS}

\section{Construcción de polímeros.}

Los polímeros son macromoléculas formadas por la unión de varios monómeros. En la actualidad se utilizan como modelo de matrices extracelulares, a través de los cuales se

pueden estudiar y correlacionar diversas funciones ${ }^{79}$. La composición de GAGs en los tejidos no sólo es altamente variable sino que además esta composición varía en estados como envejecimiento, aterosclerosis etc. Estos GAGs tienen alta carga negativa y la mayoría tienen distinto grado de sulfatación. A modo de estudiar posibles interacciones entre las variantes de apoA-I y los polímeros, construimos matrices sintéticas como modelo de composición controlable. Para diseñar estas matrices poliméricas, se eligieron monómeros que tenían grupos polares iónicos y no iónicos que podían imitar a los presentes en los GAGs naturales: 4-estirenosulfonato de sodio ( $\mathrm{SSNa}$ ) y metacrilato de 2-hidroxietilo (HEMA). Se sintetizaron dos matrices con diferentes relaciones molares SSNa: HEMA 0,75 y 0,25. La síntesis se realizó mediante polimerización radical, utilizando los reactivos persulfato de amonio (0,5\% en moles), N, N, N ', N'tetrametiletilendiamina ( $1,0 \%$ en moles) y $\mathrm{N}, \mathrm{N}$-metilen bisacrilamida $(5,0$ moles $\%)$, 
como iniciador, co-iniciador y entrecruzador, respectivamente; el \% molar se calculó sobre la base de la suma del monómero utilizado en la mezcla de incubación. Para obtener una fase de gel, se diseminó una disolución que contenía el monómero, los iniciadores y el entrecruzador en recipientes de superficie plana apropiados y se incubó a $60^{\circ} \mathrm{C}$ para acelerar la polimerización. El punto de gelificación se alcanzó después de 2 horas. Para analizar la topología de las matrices, una pieza se observó en microscopía electrónica de barrido.

\section{Marcación de apoA-I con sondas de fluorescencia}

El Cloruro de dansilo (DNCl) se une covalentemente a proteínas en los residuos de amina. La sonda se solubilizó en acetona fría y se añadió a apoA-I en buffer fosfato $\mathrm{pH}$ 8,0 en una relación molar de aproximadamente 10: 1 sonda: proteína. Se incubó durante la noche con agitación a $4^{\circ} \mathrm{C}$; posteriormente la sonda no unida se eliminó mediante elución a través de columnas NAP5 (GE Healthcare Bio-Sciences, PA). La proteína se cuantificó mediante el ensayo colorimétrico de Bradford y se calculó la eficiencia de unión mediante usando el coeficiente de extinción de $\mathrm{DNCl}$ a $340 \mathrm{~nm}$ (4.300 M -1 cm -1). Se obtuvo una eficiencia de aproximadamente 4 moléculas de sonda por proteína. De una manera similar, las proteínas se marcaron con isotiocianato de fluoresceína (FITC). Las proteínas (Wt y Arg173Pro) se diluyeron en buffer fosfato a pH 9,0, el FITC se añadió en pequeñas alícuotas de una solución madre en el mismo buffer. La eficiencia se calculó a partir de los coeficientes de extinción a $492 \mathrm{~nm}$ $\left(75.000 \mathrm{M}^{-1} \mathrm{~cm}^{-1}\right)$ siendo similar para ambas proteínas y alrededor de 5 moles de FITC por mol de proteína.

\section{Interacción apoA-I con matrices}

\section{- A través de ensayos de fluorescencia}

Para analizar si existe una unión diferencial de apoA-I a matrices con carga diferente (y cantidades relativas de grupos sulfato), se incubó DNCl-apoA-I con matrices de SSNa / HEMA en las relaciones molares 0,75 o 0,25. Se incubó un trozo de $0,05 \mathrm{~g}$ de cada matriz con proteína marcada (concentración final $3,6 \mathrm{uM}$ a $37^{\circ} \mathrm{C}$ durante 24 horas) con agitación suave (400 rpm). Las muestras siguientes se centrifugaron a $12.000 \mathrm{rpm}$ por 20 minutos; se separó el sobrenadante $(100 \mu \mathrm{l})$ y se añadió el mismo 
volumen de buffer Tris a la matriz. La fluorescencia se leyó en el lector de microplacas con filtros de excitación y emisión centrados a 360 y $535 \mathrm{~nm}$, respectivamente.

\section{- A través de microscopia confocal}

En una configuración diferente, y con el fin de comparar la afinidad de unión del mutante Arg173Pro con respecto al Wt, se añadió el mismo volumen de ambas matrices (0.75 y 0.25$)$ en cubetas de plástico caseras y se incubaron con variantes de apoA-I marcadas con FITC (concentración final $1,1 \mu \mathrm{M}$ en buffer Tris $20 \mathrm{mM} \mathrm{pH} \mathrm{7.4).} \mathrm{La}$ incubación se realizó a $37^{\circ} \mathrm{C}$ durante 24 horas. A continuación, la proteína restante en la superficie se lavó tres veces con buffer y las matrices fueron observadas bajo microscopio confocal espectral bifotónico (Centro de Microscopía Avanzada (CMA), Bío-Bío, Universidad de Concepción, Chile). Cada imagen 3D se obtuvo mediante el software Image-J, permitiendo el cálculo de la intensidad total a través de la integración de la intensidad de fluorescencia correspondiente a 100 imágenes.

\section{Interacción de proteínas con monómeros de la matriz}

A fin de determinar la posibilidad de que una distinta afinidad de las proteínas por los polímeros pueda deberse a un cambio conformacional inducido sobre las proteínas por los grupos químicos constituyentes, analizamos parámetros estructurales conocidos de las variantes en presencia de un exceso de monómeros. Arg173Pro (a una concentración final de $0,2 \mathrm{mg} / \mathrm{ml}$ ) se incubó a $37^{\circ} \mathrm{C}$ durante 24 horas con $0,5 \mathrm{mM}$ de HEMA o SSNa. La estructura de la proteína se caracterizó como se describió más arriba. Se midió fluorescencia intrínseca del Trp por excitación a $295 \mathrm{~nm}$ y se registró la emisión entre 310 y $400 \mathrm{~nm}$. Las mediciones se realizaron en un espectrofluorómetro SLM4800 mejorado por Olis (ISS Inc, Champaign, IL). La presencia de bolsillos hidrofóbicos se estimó mediante la sonda Bis-ANS. La proteína se incubó en las mismas condiciones y se añadió Bis-ANS a una relación molar 1:1 (sonda: proteína). La emisión de fluorescencia se midió por excitación a $395 \mathrm{~nm}$ y emisión registrada entre 450 y $550 \mathrm{~nm}$, respectivamente. Para detectar la agregación de tipo amiloide, se incubaron las proteínas a $0,2 \mathrm{mg} / \mathrm{ml}$ y después de 24 horas a $37^{\circ} \mathrm{C}$, se añadió tioflavina $\mathrm{T}(\mathrm{ThT})$ a una relación molar 1:1 y se midió la intensidad de fluorescencia en lector de placa usando filtros de excitación y emisión centrados a $430 \mathrm{~nm}$ y $480 \mathrm{~nm}$, respectivamente. 
En un experimento diferente, Arg173Pro se incubó con monómeros (en la misma proporción que se ha descrito arriba) ya sea en presencia o ausencia de heparina (en una relación de 10 moles por mol de proteína). Posteriormente, las muestras se separaron por electroforesis en un gel de gradiente de poliacrilamida al $4-25 \%$ (PAGGE) en condiciones nativas. Se usó tinción con Nitrato de Plata para visualizar la migración de complejos.

\section{J. PROCESAMIENTO PROTEOLÍTICO DE VARIANTES DE apoA-I.}

Como se ha descripto en varios trabajos, la activación de procesos proinflamatorios determina la secreción de metaloproteasas que pueden generar fragmentos peptídicos de distintas proteínas incluida la apoA $-\mathrm{I}^{43}$, los cuales pueden o no ser amiloidogénicos. Esta hipótesis surge como consecuencia de que en varias lesiones amiloides se aisló un péptido de 53-93 aminoácidos, correspondiente al extremo Nterminal de apoA-I. Con el fin de estudiar si esta variante posee una mayor susceptibilidad a la proteólisis incubamos a $37^{\circ} \mathrm{C}, 0.2 \mathrm{mg} / \mathrm{ml}$ de proteínas con metaloproteasa 12 en relación 1000:1 proteína: enzima. Se tomaron alícuotas a tiempo $0,15,30$ minutos, 1 y 2 horas de incubación y los productos fueron analizados mediante SDS-PAGE al 14\%. Luego se reveló mediante tinción con Nitrato de Plata, y, mediante western-Blot en las mismas condiciones a fin de visualizar la existencia de fragmentos producto de la digestión.

De la misma manera se analizó el producto de la incubación de $0,2 \mathrm{mg} / \mathrm{ml}$ de proteínas con distintas relaciones de apoA-I: Tripsina (1000:1; 750:1; 500:1; 250:1 Y 100:1) a $37^{\circ} \mathrm{C}$ durante 15 minutos y con agitación (900 rpm).

\section{K. ACTIVACIÓN DE MACRÓFAGOS HUMANOS}

Para determinar si las variantes de apoA-I son capaces activar a macrófagos y así inducir una respuesta del tipo inflamatoria, ensayamos la producción de citocinas, TNF$\alpha$ e IL-1ß en una línea celular de monocitos humanos. La línea celular de monocitos humanos THP1 (ECACC, Salisbury, UK) se creció en suspensión en medio RPMI 1640 suplementado con $10 \%$ de suero fetal bovino y conteniendo una mezcla de antibióticoantimicótico (100 U/ml de penicilina y $100 \mu \mathrm{g} / \mathrm{ml}$ de estreptomicina) y mantenidas en estufa a $37^{\circ} \mathrm{C}$ y $5 \% \mathrm{CO}_{2}$. 
Para el ensayo, las células fueron colocadas en placas de 96 wells en una concentración de $6 \times 10^{6}$ células/well, y 48 horas previas al ensayo se incubaron con PMA (ésteres de forbol) (concentración final de $5 \mathrm{ng} / \mathrm{ml}$ ) y se incubaron a $37^{\circ} \mathrm{C}$ para diferenciarlas a macrófagos (donde comienzan a crecer en monocapa adheridas). Como control positivo de activación de respuesta celular se utilizó lipopolisacárido bacteriano (LPS) y como control negativo el LPS se adicionó en presencia de su secuestrante polimixina B. Este antibiótico se adicionó a las muestras incubadas con las proteínas para eliminar los efectos de una posible contaminación con pequeñas cantidades de endotoxinas remanentes luego de la purificación de las proteínas recombinantes. Allí, fueron incubadas con $5 \mu \mathrm{g} / \mathrm{ml}$ de proteínas durante 3 horas. Se extrajo el sobrenadante y se realizó un ELISA para TNF- $\alpha$ e IL-1ß, según el protocolo descripto en cada kit (eBioscience, San Diego, CA)

A fin de testear la posibilidad que las variantes amiloidogénicas activen respuesta inflamatoria endotelial, utilizamos como modelo células endoteliales de cordón umbilical humano (HUVEC). Las mismas fueron obtenidas mediante protocolos estandarizados, crecidas en medio RPMI con $50 \mathrm{ug} / \mathrm{ml}$ de EGF (factor de crecimiento endotelial). Lamentablemente, la imposibilidad de repicarlas por razones aún no subsanadas nos impidió reportar resultados con este cultivo primario. 


\section{RESULTADOS}

\section{A. ESTABILIDAD Y CONFORMACIÓN PROTEICA}

La estabilidad de la estructura proteica fue investigada a través de ensayos de desnaturalización con $\mathrm{Gnd}-\mathrm{HCl}$, siguiendo la emisión de fluorescencia intrínseca de los residuos Trp (los cuales se encuentran en las posiciones 8, 50, 72 y 108 de apoA-I) en concentraciones crecientes de $\mathrm{GndHCl}$. Como fue evaluado anteriormente ${ }^{41}$, la desnaturalización química con $\mathrm{GndHCl}$ de apoA-I Wt puede ser descripta a pH 7,4 mediante un modelo de desnaturalización de dos estados, nativo y desnaturalizado (Figura 5.1), desde la cual puede ser estimada ${ }^{10}$ la energía libre de desplegamiento. El $\Delta \mathrm{G}^{\circ}$ medido es $2,5 \pm 0,3 \mathrm{kcal} / \mathrm{mol}$ (Tabla 1), típico de una proteína parcialmente plegada ${ }^{7}$ Al analizar el comportamiento de desnaturalización de la variante Arg173Pro, la pérdida de este patrón no permitió ajustar al modelo de dos estados, impidiendo así la estimación del $\Delta \mathrm{G}^{\circ}$. En su lugar, aún a bajas concentraciones de $\mathrm{GndHCl}$ ensayadas $(0,1 \mathrm{M})$ se observa un desplazamiento del máximo de intensidad hacia longitudes de onda mayores, lo que indica una exposición aumentada de residuos de Trp, dando indicios de disminución de la estabilidad. La concentración aparente de $\mathrm{GndHCl}$ donde la mitad de la proteína se despliega $[\mathrm{Gnd}-\mathrm{HCl}]_{1 / 2}$, también es significativamente inferior para este mutante $(0,5 \mathrm{M})$ comparado con la variante $\mathrm{Wt}(0,9 \mathrm{M})$.

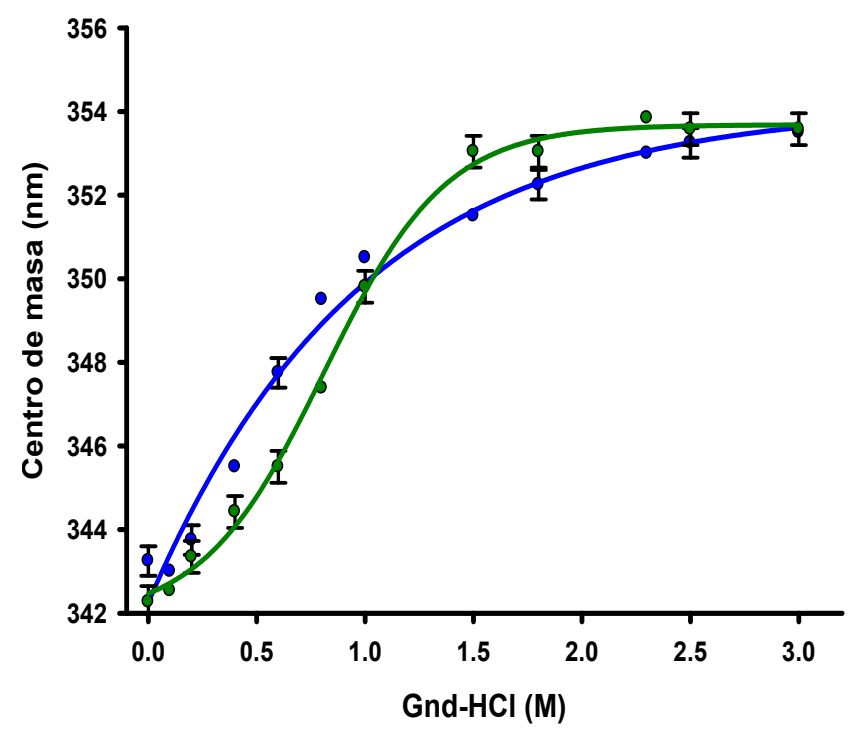

Figura 5.1 Desnaturalización química con Gnd-HCl: Las proteínas $(0.1 \mathrm{mg} / \mathrm{ml}$ en buffer Mcilvaine, pH 7.4) fueron tituladas con concentraciones crecientes de Gnd-HCl. Se midió fluorescencia intrínseca del triptofano por excitación a $295 \mathrm{~nm}$, y registrando la emisión entre 310 y $420 \mathrm{~nm}$. Con estos datos se calculó el centro de masa para cada muestra. Los círculos verdes y azules representan los datos experimentales de Wt y $\operatorname{Arg} 173 \mathrm{Pr} 0$ respectivamente.

A fin de comparar la existencia de diferencias estructurales en el estado nativo, realicé espectros de dicroísmo circular en el UV lejano (180-250 nm) (Figura 5.2). Los mismos revelaron que, si bien ambas proteínas poseen un espectro típico de una 
proteína con $\alpha$-hélice (dobles mínimos a 222 y $208 \mathrm{~nm}$ y un máximo a $191 \mathrm{~nm}$ ), la variante Arg173Pro revela una menor proporción de contenido de estructura secundaria. Si bien lamentablemente un bajo contenido de citrato en el buffer de medida introdujo ruido en la señal espectral, que impidió un barrido preciso hasta menores longitudes de onda, según los cálculos realizados, se calcula aproximadamente un $35 \%$ de reducción respecto a la variante $\mathrm{Wt}$.

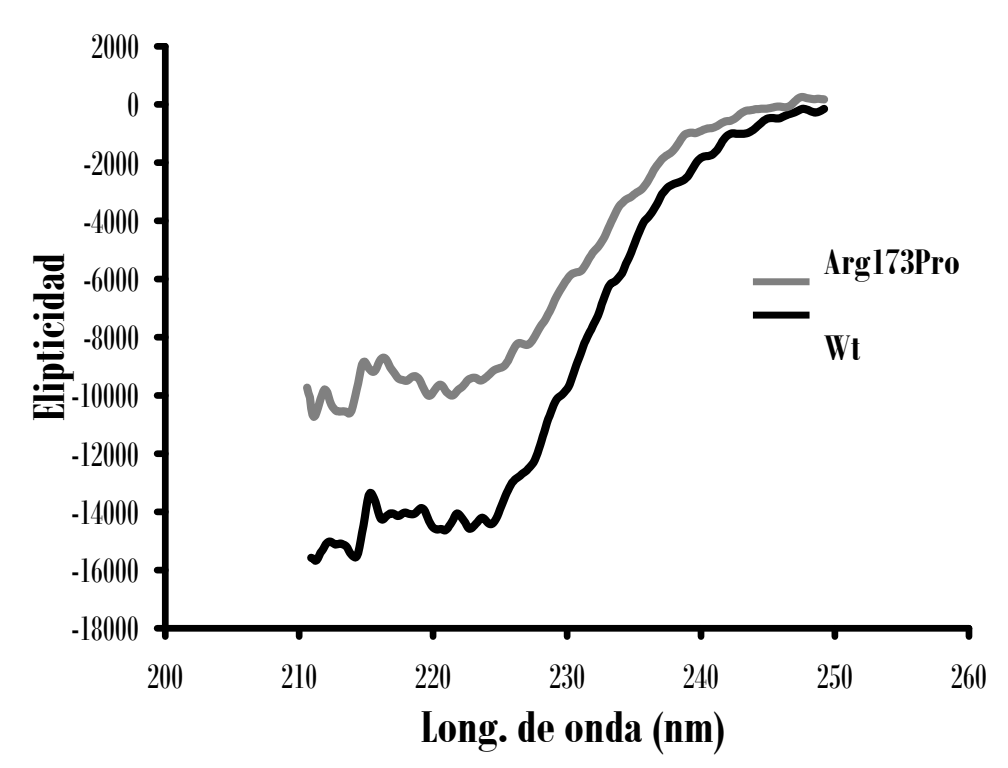

Figura 5.2. Caracterización espectroscópica de la estructura proteica: Variantes de apoA-I Wt y Argl73Pro $(0 . \mathrm{lmg} / \mathrm{ml})$ fueron disueltas en buffer Mcilvaine, pH 7,4. Espectro de dicroísmo circular en el UV lejano. Las líneas negras y gris claro corresponden a Wt y Argl73Pro respectivamente.

Los cambios en el entorno de los residuos Trp dan indicios acerca del estado conformacional de la proteína. Esto puede evidenciarse a través del ensayo de apagado (quenching) con acrilamida. Para eso se tituló cada una de las proteínas con concentraciones crecientes de acrilamida y se determinó la constante de Stern-Volmer (K). Se obtuvo un mayor valor de la constante para la variante $\operatorname{Arg} 173$ Pro (7.8 vs $5.5 \mathrm{M}^{-}$ ${ }^{1}$ para el Wt), lo que índica una mayor exposición en promedio de los residuos Trp al disolvente (Figura 5.3). 


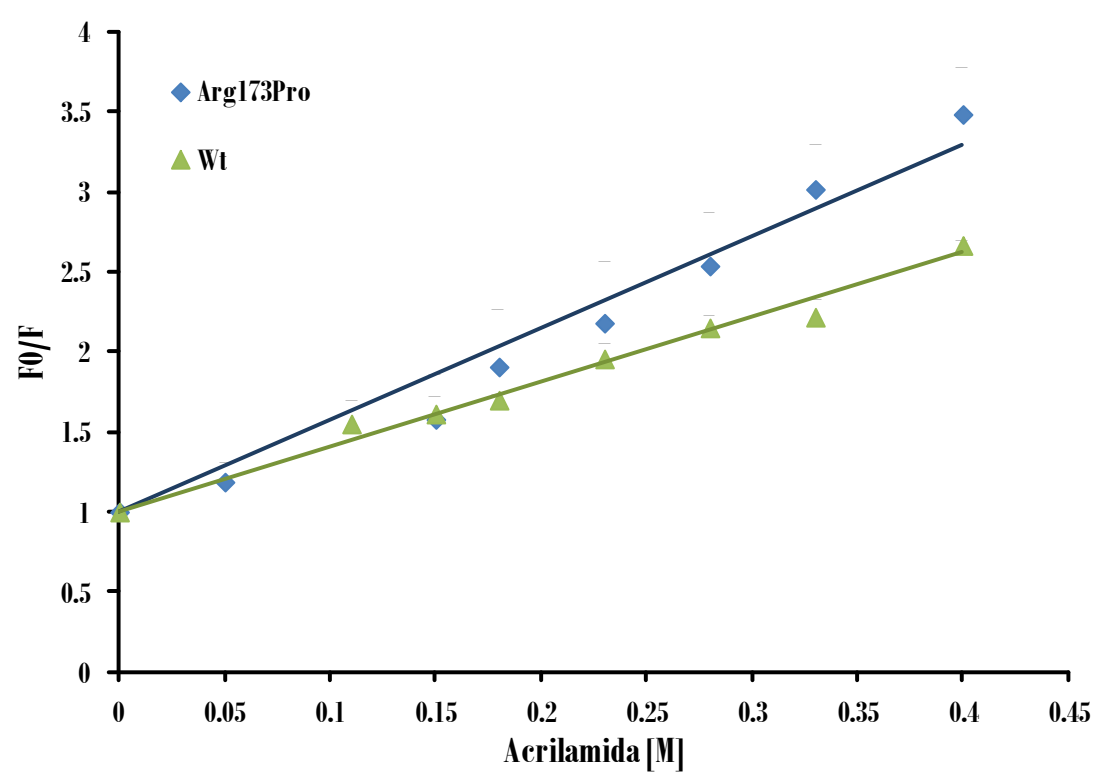

Figura 5.3: Exposición de residuos Trp mediante el apagado con acrilamida. Las proteínas (a $0.1 \mathrm{mg} / \mathrm{ml}$ en buffer Mcilvaine pH 7.4) fueron tituladas con concentraciones crecientes de acrilamida. Se registró la fluorescencia intrínseca de Trp mediante excitación a $295 \mathrm{~nm}$ y la emisión detectada a $338 \mathrm{~nm}$. El gráfico muestra la relación entre la fluorescencia a cada concentración de acrilamida (F/F0) y la intensidad a cada concentración de acrilamida. Los círculos verdes y azules representan los datos experimentales para Wt y Arg173Pro, respectivamente. Como se indica en la ecuación 5, del valor de la pendiente de la curva se extrae el valor de la constante de apagado $\mathrm{K}$

Con el fin de obtener una mayor comprensión de la estructura terciaria, las proteínas fueron tituladas con Bis-ANS, una sonda sensible a superficies hidrófobas y estructuras flexibles ${ }^{80}$. El rendimiento cuántico de fluorescencia asociada a la unión de esta sonda está de acuerdo con una organización espacial de la proteína Wt en su estado nativo del tipo glóbulo-fundido ${ }^{43,67,69,80}$. Los resultados obtenidos de este ensayo demuestran que el Bis-ANS exhibe un rendimiento cuántico más alto cuando se une a la variante Arg173Pro (Figura 5.4), lo que sugiere ya sea mayor exposición de residuos hidrofóbicos o un aumento relativo en la flexibilidad proteica que permite mayor captación de la sonda. 


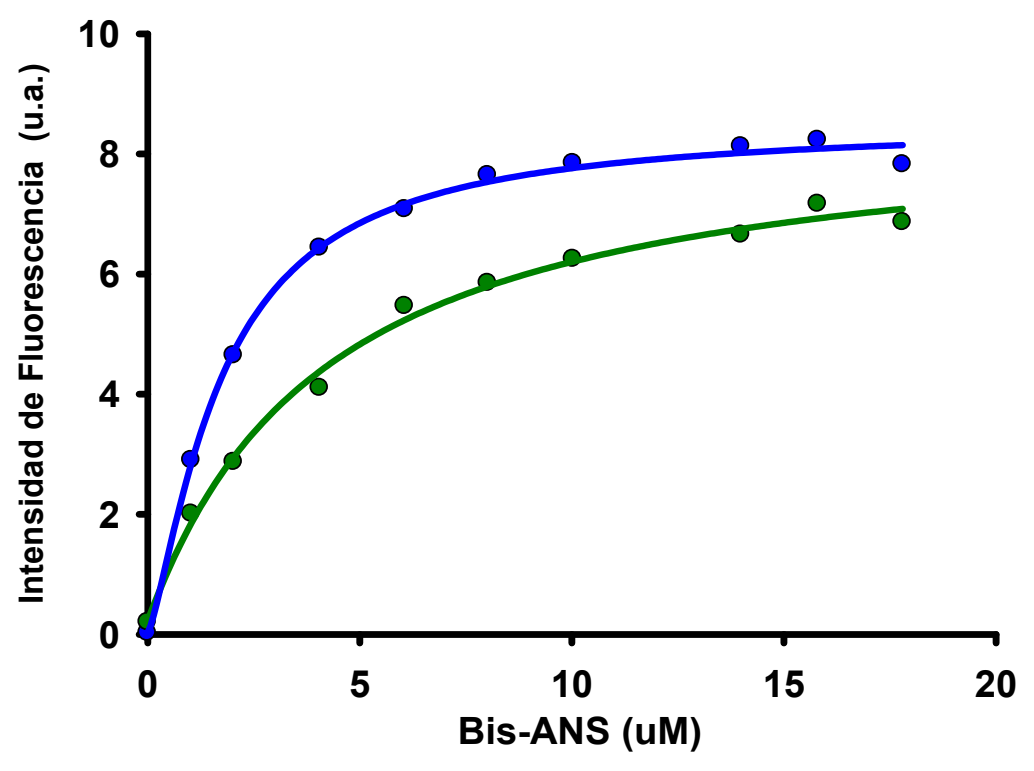

Figura 5.4 Titulación con Bis-ANS. Las proteínas ( $0,1 \mathrm{mg} / \mathrm{ml}, 3,6$ ull) fueron incubadas con concentraciones crecientes de Bis -ANS. La sonda fue excitada a $360 \mathrm{~nm}$, y se registró el valor de emisión correspondiente al máximo de fluorescencia para esta sonda (408nm). Los círculos verdes y azules representan los datos experimentales para Wt y Argl73Pro,

En conjunto, estos resultados sugieren que la sustitución de una Arginina por una Prolina induce cambios conformacionales del dominio N-terminal de apoA-I (donde se encuentran los residuos de Trp) que resultan en una mayor exposición de estos residuos de Trp, y de la superficie hidrófoba al medio acuoso.

\section{B. PROPIEDADES DE UNIÓN DE LÍPIDOS DE LAS VARIANTES LIBRES DE LÍPIDOS}

Con el fin de detectar si Arg173Pro mantiene su papel funcional en la solubilización de los lípidos, incubamos esta proteína con vesículas multilamelares de DMPC a la temperatura de transición $\left(24^{\circ} \mathrm{C}\right)$ y comparamos, siguiendo la disminución de la turbidez a $340 \mathrm{~nm}$, su capacidad para solubilizar este lípido formando complejos proteínas: lípidos. Como la figura 5.5A muestra, el menor aclaramiento en presencia de Arg173Pro (línea gris continua) indica que esta variante es menos eficiente que el $\mathrm{Wt}$ (línea punteada). Además, los productos después de 1 (líneas 2 y 3) ó 2 h (líneas 4 y 5) de incubación se caracterizaron por PAGGE (Figura 5.5B). Como se observó previamente, en esas condiciones Wt rinde una población homogénea de alrededor de $230 \mathrm{kDa}$, lo que indica una alta eficiencia para solubilizar y reorganizar la DMPC 
(líneas 2 y 4). En cambio, la mayor parte de la Arg173Pro permaneció como proteína pobre en lípidos y una cierta cantidad se recombinó en partículas de tamaño superior (líneas 3 y 5 en la misma figura).

A

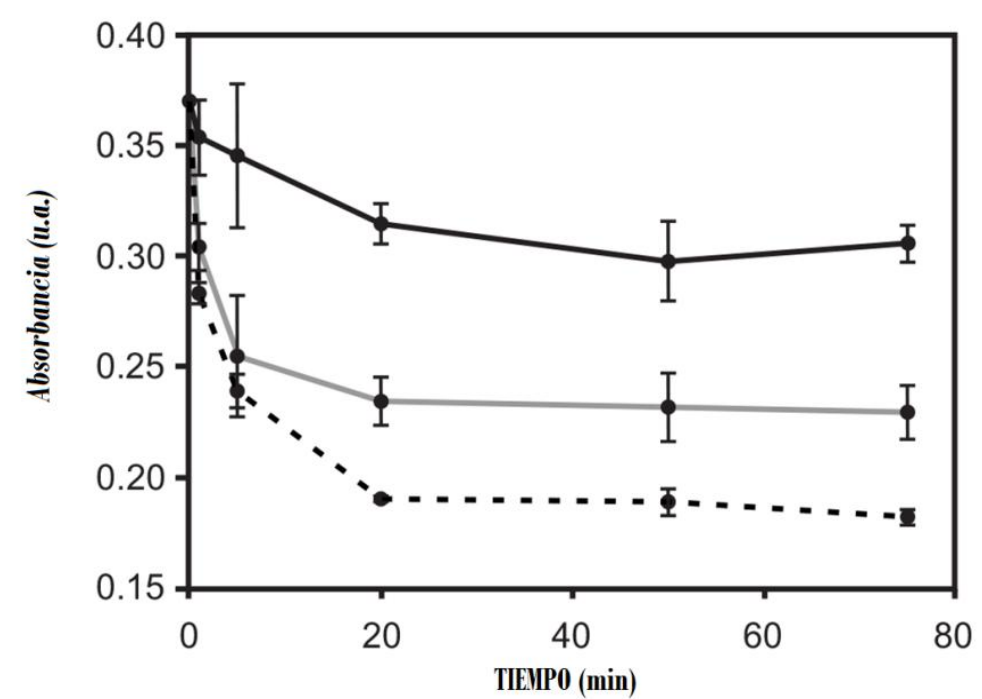

B

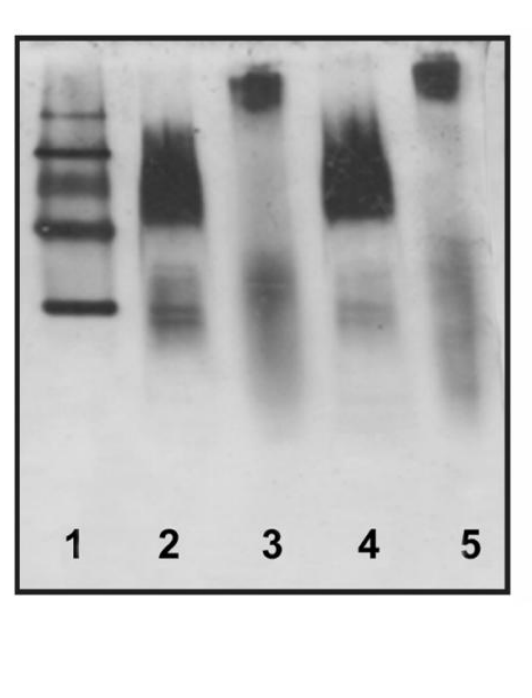

0

B

Figura 5.5: Caracterización de formación espontánea de complejos Lípido:proteína. A) Liposomas multilamelares de DUMPC fueron incubados a $24^{\circ} \mathrm{C}$ y se midió absorbancia a $340 \mathrm{~nm}$ sin proteína (línea negra), con Wt (línea punteada) o Arg173Pro (línea gris), relación molar lípido a proteína 40:I. B) PAGGE nativo en gradiente 4-24\%. Se sembraron los productos finales luego de la incubación por 102 hs con DIIPC a $24{ }^{\circ} \mathrm{C}$ de Wt (líneas 2 y 4) o Argl73Pro (líneas 3 y 5), respectivamente. La línea 1 corresponde a estándar de alto peso molecular $(669,440,232,140$ y $67 \mathrm{klla}$. Amersham Biosciences, UK)

\section{FORMACIÓN DE AGREGADOS TIPO AMILOIDE}

El plegamiento anómalo de las proteínas contribuye en gran parte a la formación de fibrillas amiloides y otras especies potencialmente patógenas, las cuales se depositan causando graves enfermedades. Para determinar si la variante Arg173Pro presenta mayor tendencia a agregarse a $\mathrm{pH}$ fisiológico, utilizamos las propiedades de la sonda fluorescente tioflavina $\mathrm{T}$ ( $\mathrm{ThT}$ ), la cual posee un rendimiento cuántico de fluorescencia en buffer acuoso que aumenta tras la unión a proteínas amiloides ${ }^{73,81}$. La apoA-I Wt y Arg173Pro fueron incubadas a una concentración de $0,2 \mathrm{mg} / \mathrm{ml} \mathrm{a} 37^{\circ} \mathrm{C}$ y $\mathrm{pH}$ fisiológico $(7,4)$ durante 48 hs. A continuación se agregó ThT en relación molar 1:1 sonda: proteína y se midió la fluorescencia, la cual resultó ser baja para la variante Wt, pero para Arg173Pro aumentó significativamente (Figura 5.6). 


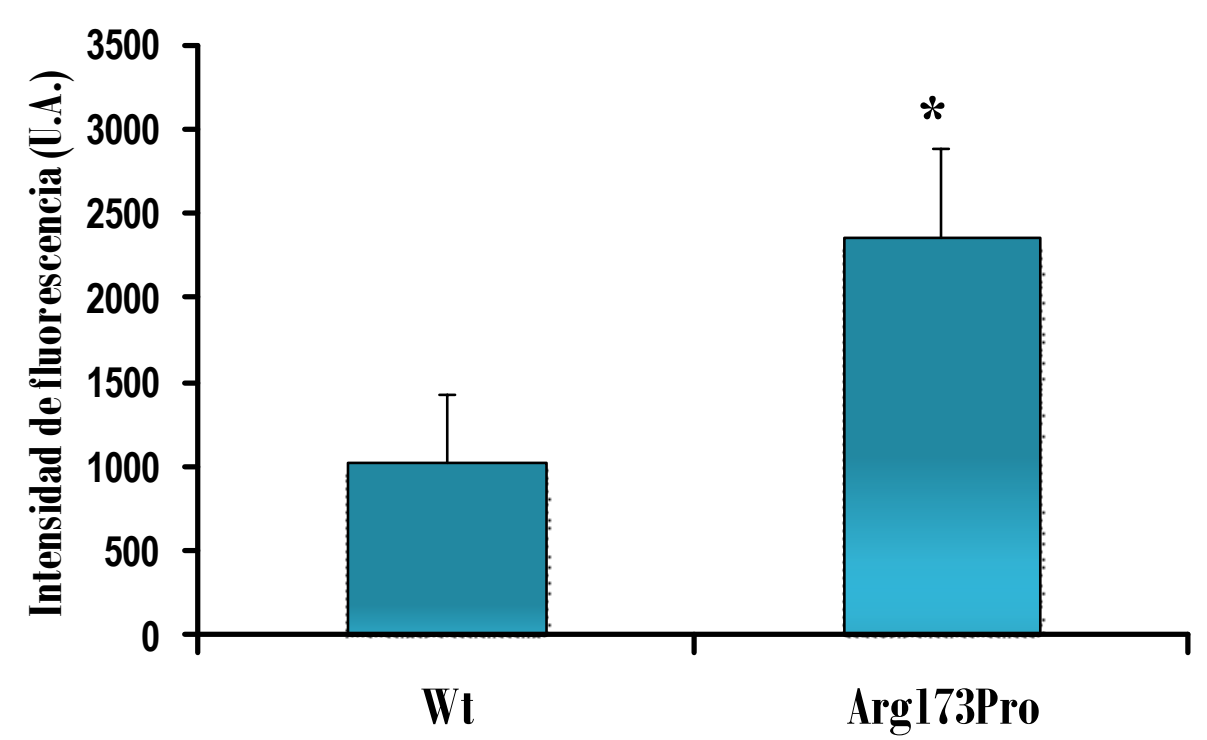

Figura 5.6 Caracterización de agregados de Arg173Pro a pH 7.4: Unión de Tioflavina T a apoA-I. Las proteínas $\left(0.2 \mathrm{mg} / \mathrm{ml}\right.$ en buffer Mcilvaine a pH 7.4) fueron incubadas por $48 \mathrm{hs} \mathrm{a} 37^{\circ} \mathrm{C}$ y la ThT fue agregada en relación molar l:1. La fluorescencia a $480 \mathrm{~nm}$ se cuantificó en lector de placa (excitación a $430 \mathrm{~nm}$ ). Las barras corresponden al promedio \pm desviación estándar. Las diferencias significativas estadísticamente en las condiciones experimentales fueron evaluadas por test de Student. Los símbolos “*”, denotan una diferencia con respecto al Wt a p<0.05 (Valor de p 0.02)

Esta evidencia sugiere mayor formación de complejos pro amiloidogénicos por parte de la variante mutada. En un ensayo paralelo se incubaron muestras en iguales condiciones y se analizó dispersión de luz (scattering) a $350 \mathrm{~nm}$. La mayor absorbancia a $350 \mathrm{~nm}$ de la variante Arg173Pro respecto al Wt (Tabla 5.1), indica la formación de complejos de mayor tamaño de las partículas en suspensión en esta muestra. 
TABLA 5.l: Caracterización de fluorescencia de las variantes apo A-I Wt y Arg173Pro a pH 5 y 7.4

\begin{tabular}{|c|c|c|c|c|c|c|}
\hline Variantes & $K\left(\mathbf{M} \mathbf{I}^{-1}\right)^{\mathbf{A}}$ & $\begin{array}{c}\Delta G^{\circ} \text { desnat. } \\
\text { (Kcal/mol) }\end{array}$ & {$\left[\right.$ GndHCl $_{1 / 2}{ }^{C}$} & Scattering" & $\mathrm{E}^{\mathrm{E}}$ & $\overline{\text { BisANS/Trp }}$ \\
\hline \multicolumn{7}{|l|}{ pH 7.4} \\
\hline Wt & $5.6 \pm 0.4$ & $2.5 \pm 0.3$ & $0.9 \pm 0.2$ & $1.0 \pm 0.3$ & & \\
\hline Arg173Pro & $7.8 \pm 0.9$ & $\mathrm{~N} / \mathrm{A}$ & $0.5 \pm 0.3$ & $2.2 \pm 0.4$ & $0.23 \pm 0.03$ & $1.3 \pm 0.4$ \\
\hline \multicolumn{7}{|l|}{ pH 5} \\
\hline Wt & $5.8 \pm 0.9$ & $2.4 \pm 0.3$ & $0.9 \pm 0.3$ & $2.2 \pm 0.1$ & & \\
\hline Arg173Pro & $6.1 \pm 0.8$ & $\mathrm{~N} / \mathrm{A}$ & $0.5 \pm 0.2$ & $6.2 \pm 2.2$ & $0.38 \pm 0.04$ & $1.4 \pm 0.4$ \\
\hline
\end{tabular}

A: Constante de Stern-Volmer para el quenching de Trp por Acrilamida

B: Cambio de enrgía libre de desplegado

C: Concentración a la cual la mitad de la proteína es desplegada

D: Dispersión de luz de proteínas $(0.2 \mathrm{mg} / \mathrm{ml})$ medidas luego de 48 hsde incubación a $37^{\circ} \mathrm{C}$ con excitación y emisión a $350 \mathrm{~nm}$.

E: Eficiencia de transferencia de energía de resonancia (E) Trp calculada según ecuación (7).

F: Razón de intensidad de fluorescencia asociada a Bis-ANS

A fin de confirmar la morfología de los agregados proteicos, se utilizó microscopía de fuerza atómica (AFM). La variante de apoA-I Arg173Pro fue incubada a una concentración de $0,5 \mathrm{mg} / \mathrm{ml}$ a $37^{\circ} \mathrm{C}$ y $\mathrm{pH} 7,4$ durante 24 horas. La muestra se depositó sobre mica y se observó como se indica en Métodos. Se evidenció la presencia mayoritaria de agregados de tamaño heterogéneo (Figura 5.7A), e incluso la presencia de algunas estructuras alargadas detectadas a mayor aumento (recuadro amplificado). 
A
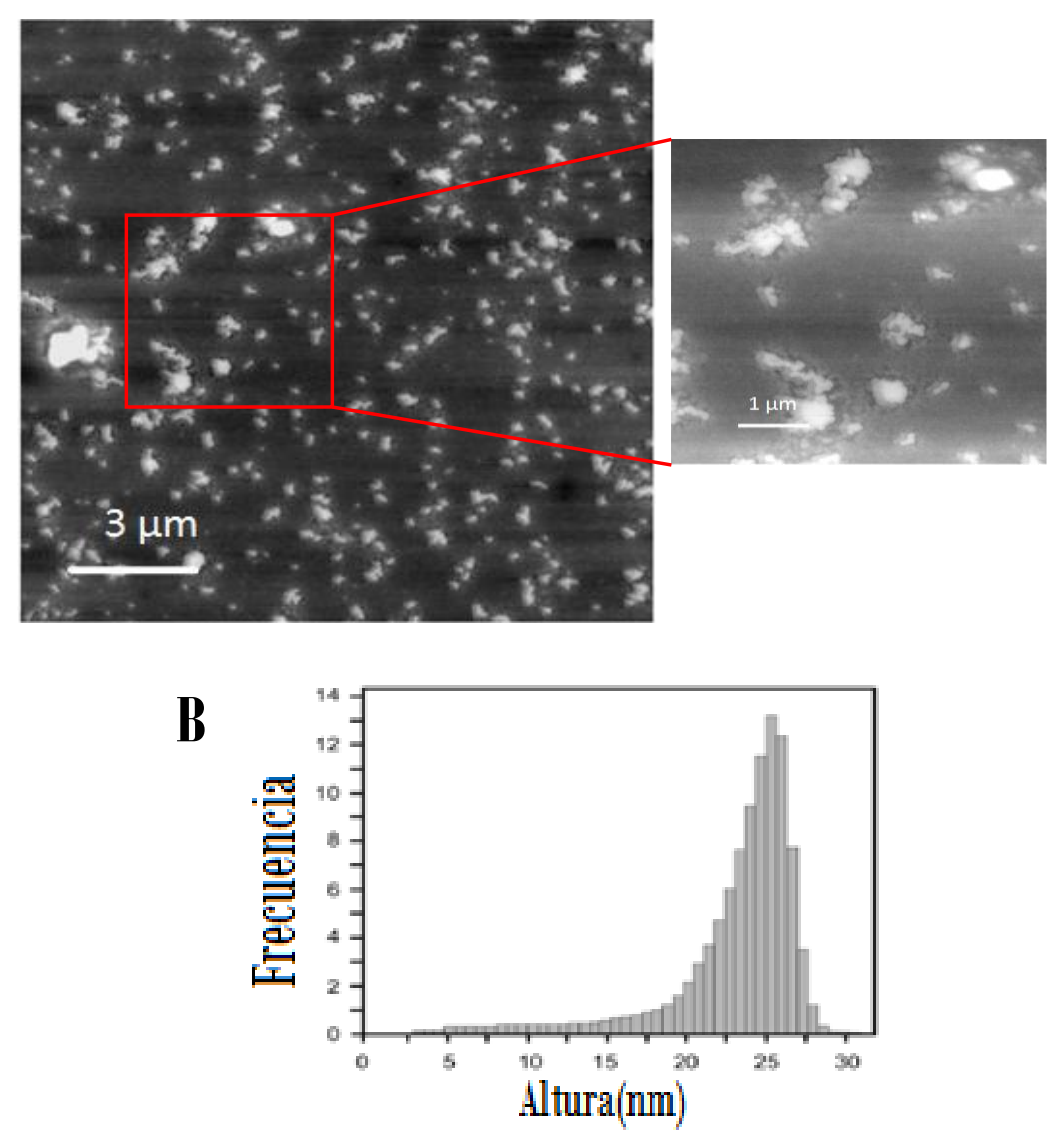

Figura 5.7. Caracterización de la moriología de agregados Arg173Pro mediante AFM. Las proteínas $(0.5 \mathrm{mg} / \mathrm{ml})$ fueron incubadas durante 24 horas y montadas sobre discos de mica. A) La muestra fue representada por oligómeros de tamaño heterogéneo cubriendo la superiicie de la mica. El recuadro representa la estructura magnificada, permitiendo así observar agregados elongados con forma protofibrilar. Las barras muestran la escala usada en cada caso. B) Histograma de distribución de las alturas de los oligómeros obtenida desde mediciones en el plano $Z$.

A fin de estimar las dimensiones de los oligómeros, medimos su altura y se representó en un histograma (Figura 5.7B).

Se observó una distribución amplia, monomodal y ligeramente sesgada con la mayoría de los agregados que mostraron una altura entre 22 y $25 \mathrm{~nm}$. Este patrón es significativamente diferente del observado para la variante Wt ensayada en las mismas condiciones, en la que una distribución del tamaño homogénea, de oligómeros más pequeño es el rasgo característico ${ }^{41}$. Tras la agregación de la variante Arg173Pro, se observa una disminución en la intensidad en el UV lejano de CD (especialmente a pH $5,0)$. Sin embargo, no hubo información concluyente acerca de la naturaleza de los agregados debido a la elevada proporción de proteína nativa restante soluble. 


\section{EFECTO DEL PH SOBRE LA ESTRUCTURA DE LA PROTEÍNA, LA ESTABILIDAD Y LA PROPENSIÓN A LA AGREGACIÓN}

Si bien el corrimiento estructural debido a la mutación en la proteína podría per se aumentar la tendencia de agregación, otros factores externos del entorno, como ser cambios de $\mathrm{pH}$, podrían favorecer la formación de estructuras amiloides ${ }^{19}$. Se infiere que, como la variante Arg173Pro pierde un residuo cargado positivamente, la carga neta de la proteína se encontraría alterada. Por lo tanto, analicé la influencia del pH ácido en la conformación de esta variante a través de CD en el UV lejano y analizando su desnaturalización química con $\mathrm{GndHCl}$. Las proteínas fueron incubadas a $0,1 \mathrm{mg} / \mathrm{ml} \mathrm{a}$ pH 5,0. El espectro de CD en el UV lejano (Figura 5.8A) y el perfil de desnaturalización química con GndHCl (Figura 5.8B) del mutante Arg173Pro fueron conservados y se muestran casi indistinguibles de los observados a pH 7,4. Fue demostrado previamente que una leve disminución en el pH local no induce cambios drásticos en la estructura de la proteína Wt a tiempos cortos de incubación a temperatura ambiente ${ }^{43}$.

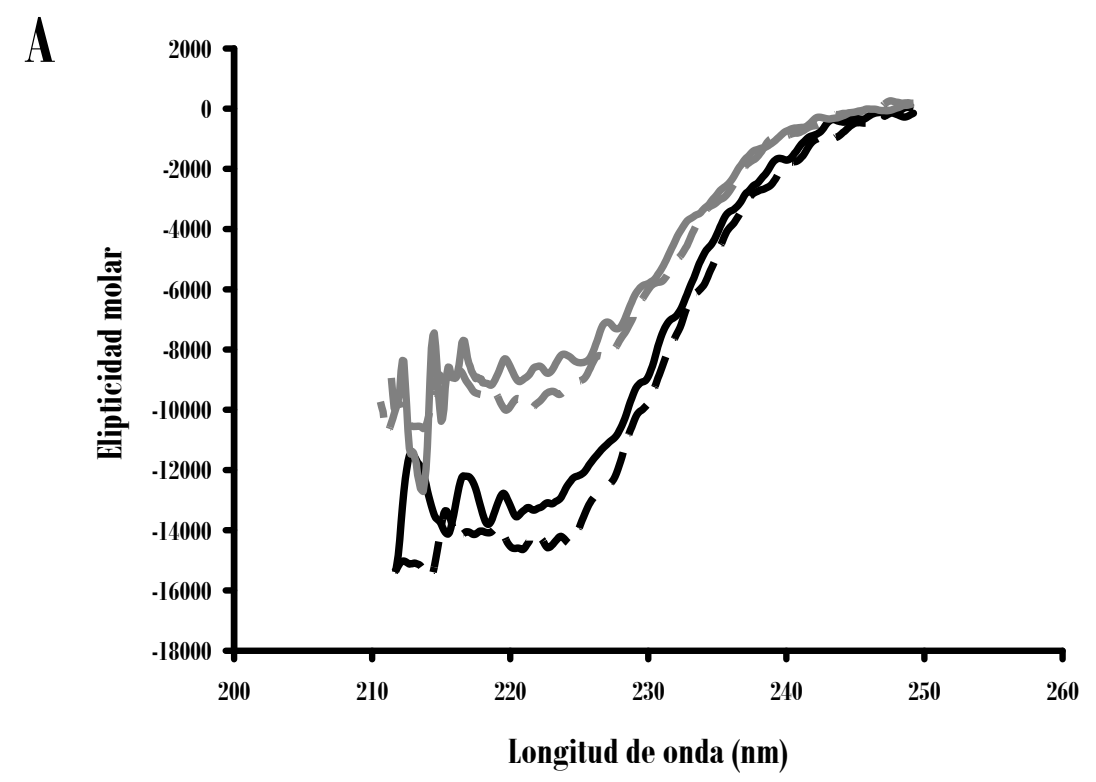




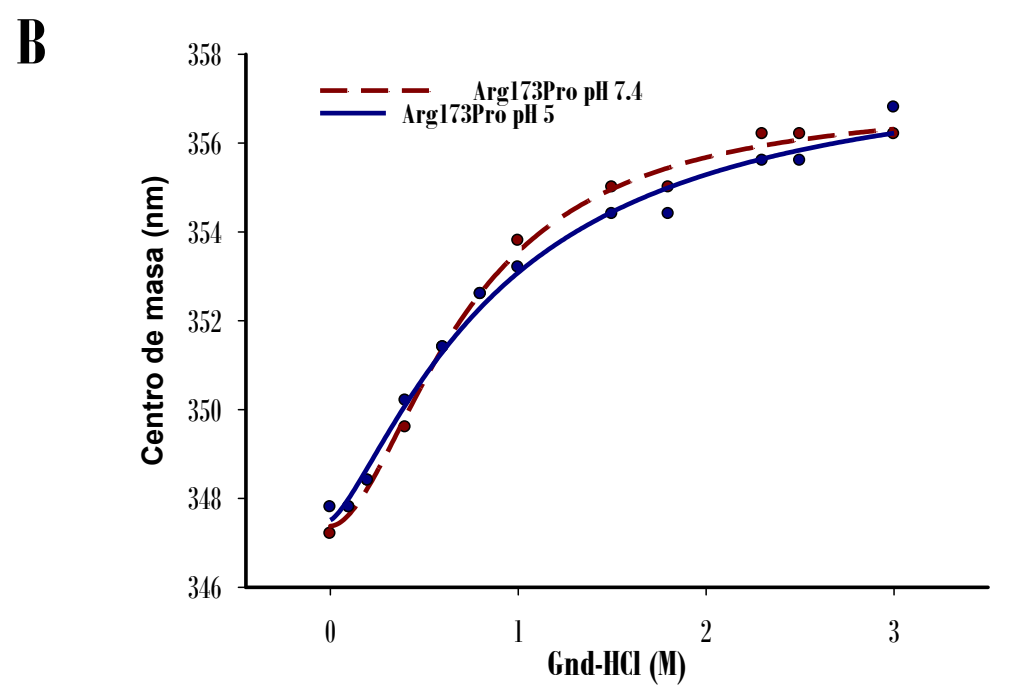

Figura 5.8: Estructura proteica, estabilidad y tendencia a la agregación a pH 5,0. A) Las variantes proteicas fueron disueltas a $0,1 \mathrm{mg} / \mathrm{ml}$ en buffer MIcllvaine pH 5,0 y se registró el espectro de dicroísmo circular en el UV lejano. Las líneas continuas negra y gris oscura corresponden a variantes Wt y Arg173Pro, respectivamente. Para facilitar la comparación, las líneas discontinuas corresponden a ambas proteínas medidas a pH 7.4. B) La Arg173Pro (0.1 mg/ml, pH 5,0) fue incubada con concentraciones crecientes de Gnd-HCl y se calculó el centro de masa de fluorescencia del triptofano (círculos azules, línea contínua). Aquí nuevamente, para facilitar la comparación, la línea discontinua (círculos rojos) corresponde a las proteínas medidas a $\mathrm{pH} 7,4$.

Para obtener más información en el efecto del $\mathrm{pH}$ sobre la estructura proteica, analicé la eficiencia de transferencia de energía desde Trp al aceptor Bis-ANS (sonda fluorescente). Dado que el FRET ocurre entre residuos cercanos entre sí (entre 10$100 \AA$ ), esta determinación nos permite analizar cambios en la organización espacial del Trp. Así, la emisión del donor Trp por excitación directa (a 295 nm, curva verde en la Figura 5.9 A), disminuye en presencia del aceptor Bis-ANS, siendo usada esa energía para su excitación (línea roja punteada). El máximo de fluorescencia en la emisión del aceptor puede ser obtenido por su excitación directa a $360 \mathrm{~nm}$ (curva azul cortada). La eficiencia de transferencia de energía se detecta ya sea por la disminución en la intensidad de emisión de los residuos de Trp, o por el aumento de la fluorescencia del Bis-ANS .

A fin de realizar estos ensayos, la variante Arg173Pro fue llevada a pH 7,4 ó 5,0, se midió la fluorescencia del Trp (circulo negro encuadrado en la Figura 5.9 B), y luego se adicionó Bis-ANS, determinando nuevamente el espectro de emisión con excitación a $295 \mathrm{~nm}$. FRET se calculó usando la ecuación (2) en base a la disminución de emisión del Trp en estas condiciones. 
Como se muestra en la Tabla 1, la eficiencia de transferencia de energía es 0,38 a $\mathrm{pH} 5,0$, un valor de aproximadamente $15 \%$ más alto que el medido a $\mathrm{pH} 7,4(0,23)$. Bajo esta condición ácida, hay un pequeño, aunque no significativo, aumento de la relación de Bis-ANS (por excitación directa) relativo a la emisión de fluorescencia de Trp, (Tabla 5.1). Estos resultados indican un cambio menor aunque sensible en la conformación de esta proteína ante un descenso momentáneo de pH.

Esta información se registró después de la adición por etapas de GndHCl. La figura $9 \mathrm{~B}$ indica que la fluorescencia del Bis-ANS tanto por excitación directa como por FRET disminuye bruscamente siguiendo una tendencia monótona al aumentar la concentración de $\mathrm{GndHCl}$. Esto sugiere, en apoyo a lo conocido para la estructura de la apoA-I, la presencia de una estructura flexible con parches hidrofóbicos expuestos al máximo en el estado nativo. El efecto fue similar en ambos pHs probados.

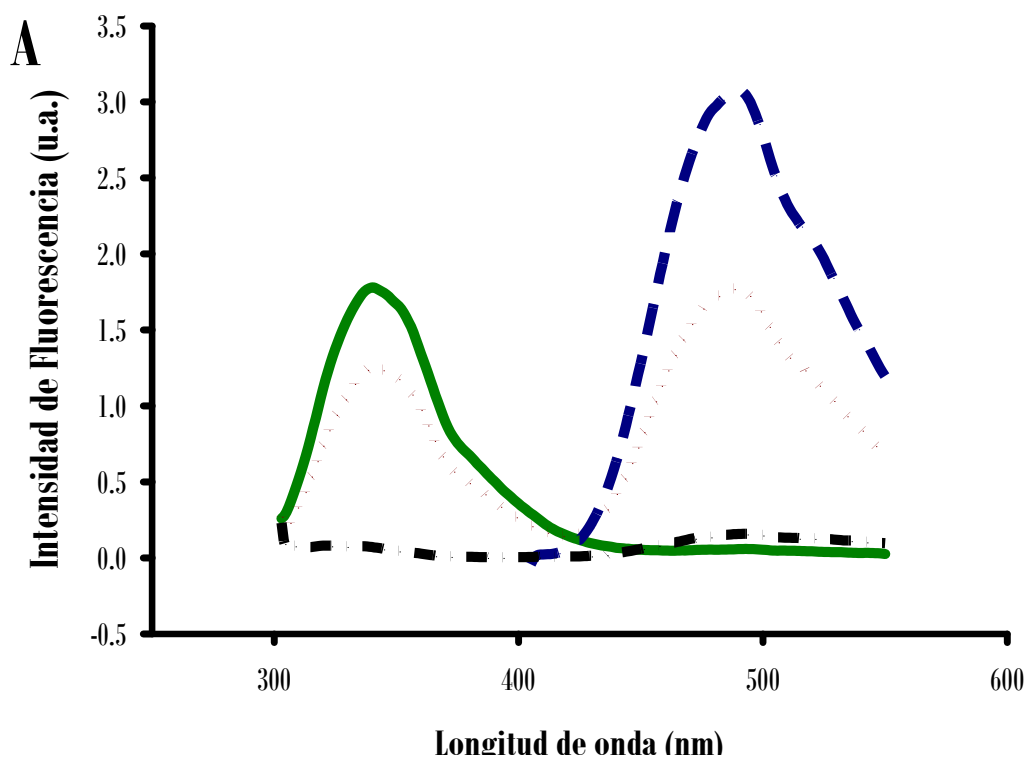




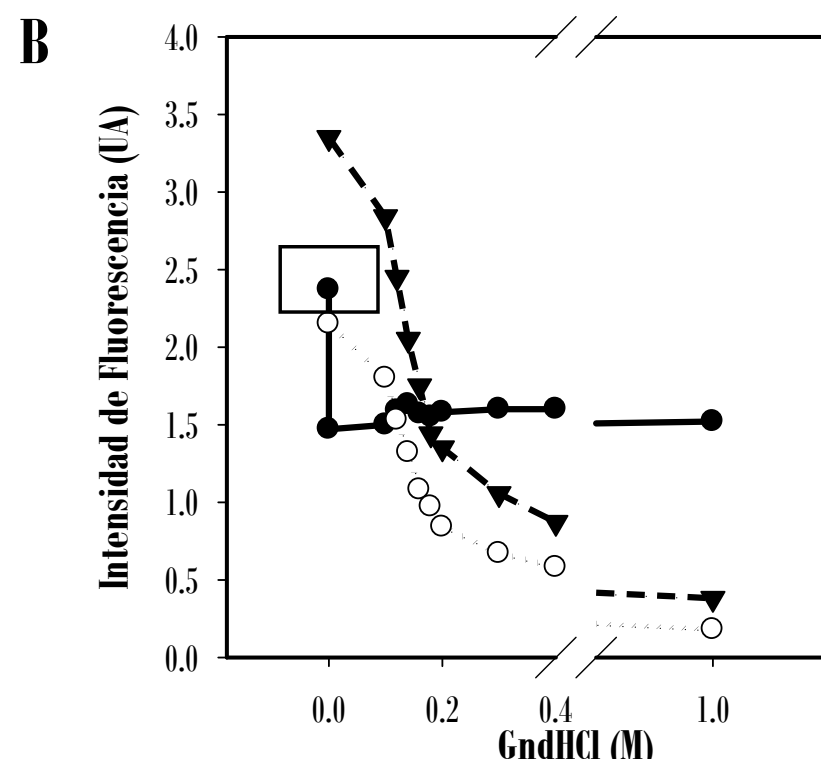

Figura 5.9: Análisis de transierencia de energía del Trp a Bis-ANS . A) La variante Arg173Pro fue disuelta (0,1 $\mathrm{mg} / \mathrm{ml}$ ) en buffer Mcilvaine y se midió la fluorescencia al triptofano (excitación a 295nm, línea continua). Posteriormente se agregó Bis-ANS y se registró el espectro de emisión (excitación a $295 \mathrm{~nm}$, línea punteada). La excitación directa del Bis-ANS fue obtenida a 395nm (línea azul discontinua). La línea punteada y discontinua representa la excitación del Bis-AVS a $295 \mathrm{~nm}$ en el buffer sin proteína. La eficiencia fue calculada midiendo la intensidad de fluorescencia del Trp a la longitud de onda de máxima emisión (335nm). B) La misma proteína fue disuelta como en A) y la intensidad de emisión del Trp (círculos negro remarcado en un cuadrado) fue registrada; a continuación se agregó Bis-ANS y la intensidad de fluorescencia medida por FRET (círculos vacíos), o por excitación directa (triángulos negros). Posteriormente se registraron estos valores ante cada la adición de cantidades crecientes de GndHCl.

A continuación, se procedió a analizar la tendencia de las proteínas a agregarse a un $\mathrm{pH}$ ácido. Las mismas se incubaron en buffer citrato-fosfato a $0,2 \mathrm{mg} / \mathrm{ml}$ por $48 \mathrm{hs}$ a $37^{\circ} \mathrm{C}$ y pH 5,0. Posteriormente se agregó ThT en relación 1:1 Proteína: sonda, se midió intensidad de fluorescencia en lector de placa (Excitación $430 \mathrm{~nm}$; emisión $485 \mathrm{~nm}$ ). Se observó que la variante Arg173Pro exhibe un mayor nivel de intensidad de emisión de ThT que la proteína Wt (Figura 5.10). 


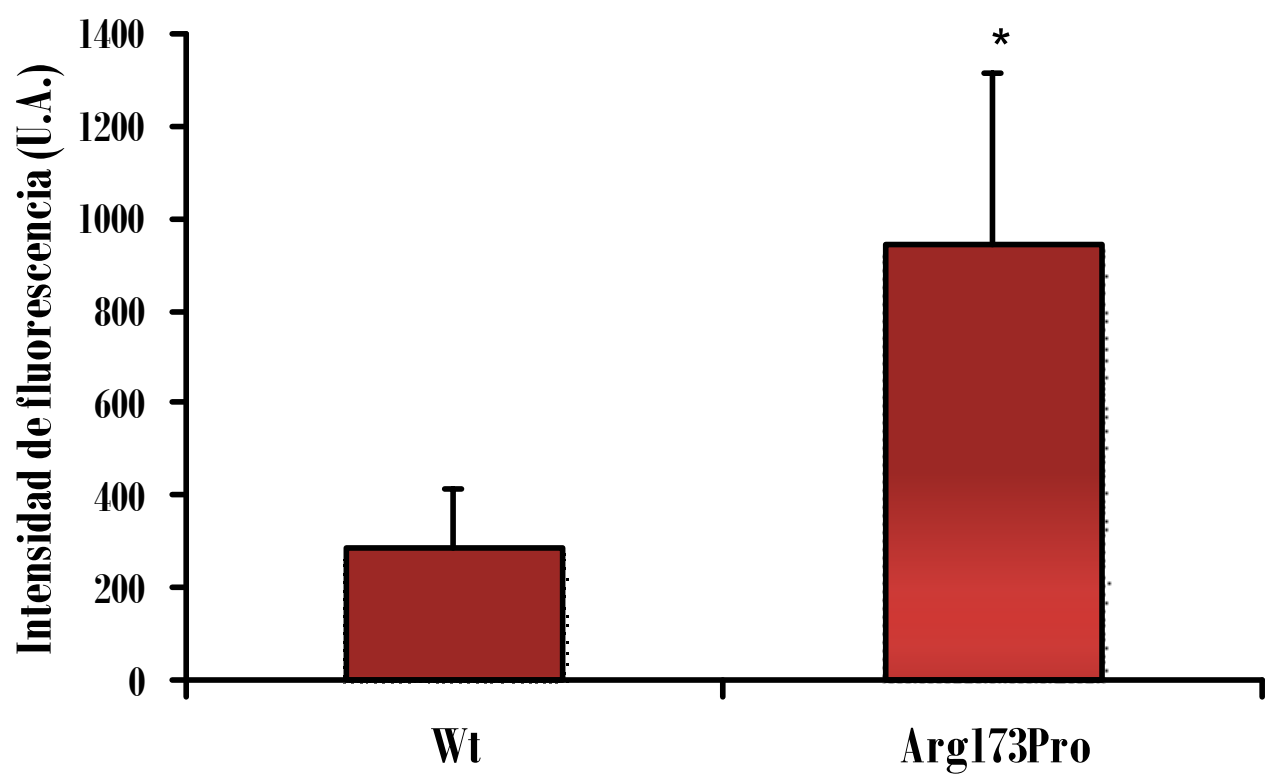

Figura 5.10: Unión de ThT a apoA-I a pH 5. Proteínas (a 0,2mg/ml en buffer IIc Ilvaine pH 5,0) fueron incubadas por 48 hs a $37^{\circ} \mathrm{C}$ y la Tioflavina T se agregó en relación molar 1:1 (proteína: sonda). La intensidad de fluorescencia fue cuantificada en lector de placa a $400 \mathrm{~nm}$ (excitación a $430 \mathrm{~nm}$ ). Las barras corresponden al promedio \pm desviación estándar. Las diferencias estadísticamente significativas entre las condiciones experimentales fueron evaluadas por Test T-student. El símbolo “*” denota una diferencia con respecto al Wt a $p<0,05$. (Valor de $p=0,04$ )

\section{E. UNIÓN DE LIGANDOS}

\section{Interacción con dodecil sulfato de sodio (SDS)}

La conversión de proteínas solubles en agregados mal-plegados por lo general implica transiciones estructurales que conducen a la interrupción parcial o completa de la estructura nativa. A lo largo de esta vía, se ha sugerido que las interacciones débiles de la proteína con moléculas pertenecientes al microambiente podrían favorecer el desplazamiento del equilibrio hacia una conformación patológica. El SDS imita algunas características de las membranas biológicas, y ha sido descrito como un agente de inducción de la formación de fibrillas a partir de diferentes péptidos y proteínas cuando se usa debajo de la concentración micelar crítica (CMC: $0,7 \mathrm{mM})^{82,83}$. Dentro de este marco, se analizó el efecto del SDS sobre la agregación de la proteína Wt y su mutante patológica, y el efecto que la disminución de $\mathrm{pH}$ podría provocar en la promoción de esta interacción. Se sabe que la CMC del SDS depende de la fuerza iónica del medio, por lo tanto previamente determiné la CMC del SDS en el buffer utilizado. Para tal fin titulé cantidades crecientes de SDS (desde 0,1 a $1 \mathrm{mM}$ ), sobre el buffer de trabajo conteniendo $4 \mathrm{uM}$ de Bis-ANS. El aumento significativo de la fluorescencia del BisANS (dado por la formación de micelas por encima de la CMC), ocurrió a 
concentraciones de $0.8 \mathrm{mM}$ (Figura 5.11 A). Finalmente, al medir la señal de ThT ante dichas concentraciones de SDS en buffer, determinamos la concentración de o.2 mM como la más apropiada ya que además produce el menor valor de background (Figura $5.11 \mathrm{~B})$

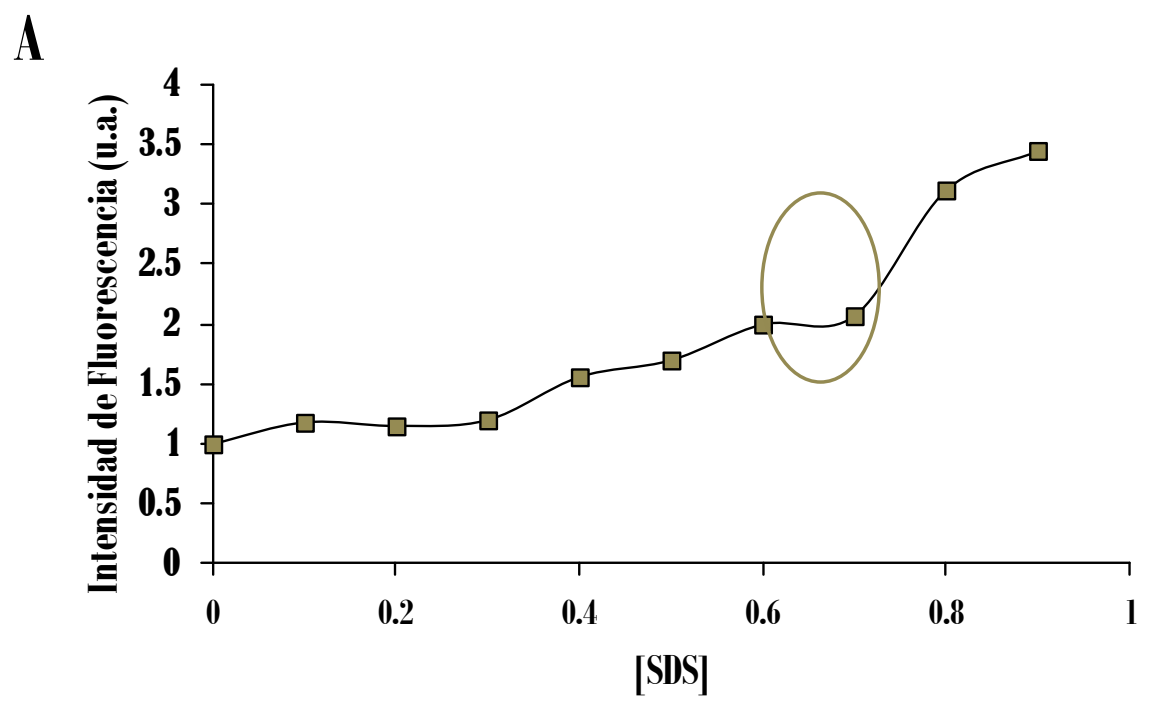

B

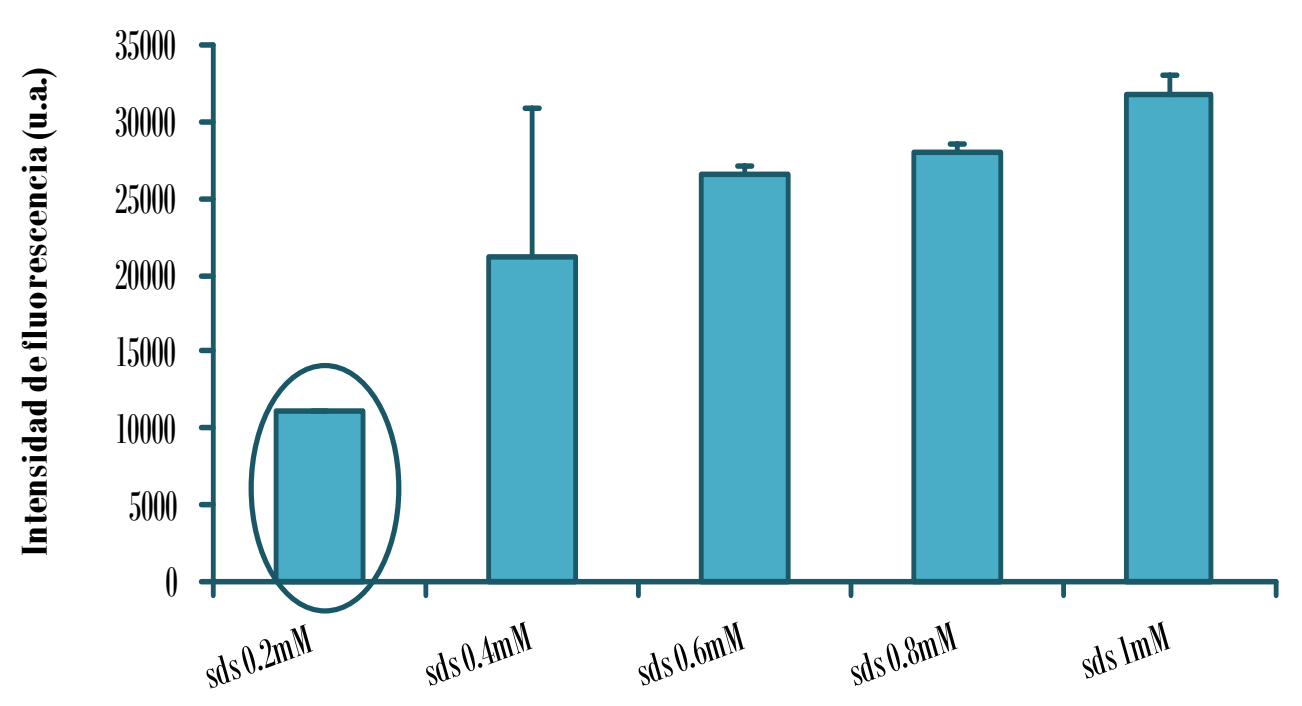

Figura 5.11: DETERMIINACIÓN DE LA CVI: A) concentraciones crecientes de SDS (0,1-1 mM) se agregaron sobre buffer Mcllvaine conteniendo 4 ull de bis-ANS. El círculo muestra la concentración de SDS donde el incremento notorio de fluorescencia indica la formación de micelas. B) El gráfico de barras en turquesa muestra la fluorescencia de ThT de los blancos a cada concentración de SDS. El círculo muestra la concentración de SDS que presenta menor fluorescencia inespecíiica. presencia y ausencia de proteína, respectivamente), decidimos realizar los ensayos en esas condiciones ( $0.2 \mathrm{mU}$ de SDS).

Se incubaron las proteínas durante $48 \mathrm{hs}$ a $0,2 \mathrm{mg} / \mathrm{ml}, 37^{\circ} \mathrm{C}$ a $\mathrm{pH} 5,0$ ó 7.4. Luego se agregó tioflavina en relación 1:1 y se midió su fluorescencia. Como muestra la figura 5.12A, la incubación de cada proteína con $\operatorname{SDS} 0,2 \mathrm{mM}$ (ya sea $\mathrm{pH}$ 5,0 ó 7,4) 
provoca mayor unión a ThT, siendo este efecto más pronunciado para la variante Arg173Pro, y es más notorio a pH 5,0. Esta unión disminuye en presencia de $\mathrm{NaCl}$ (Figura 5.12B).
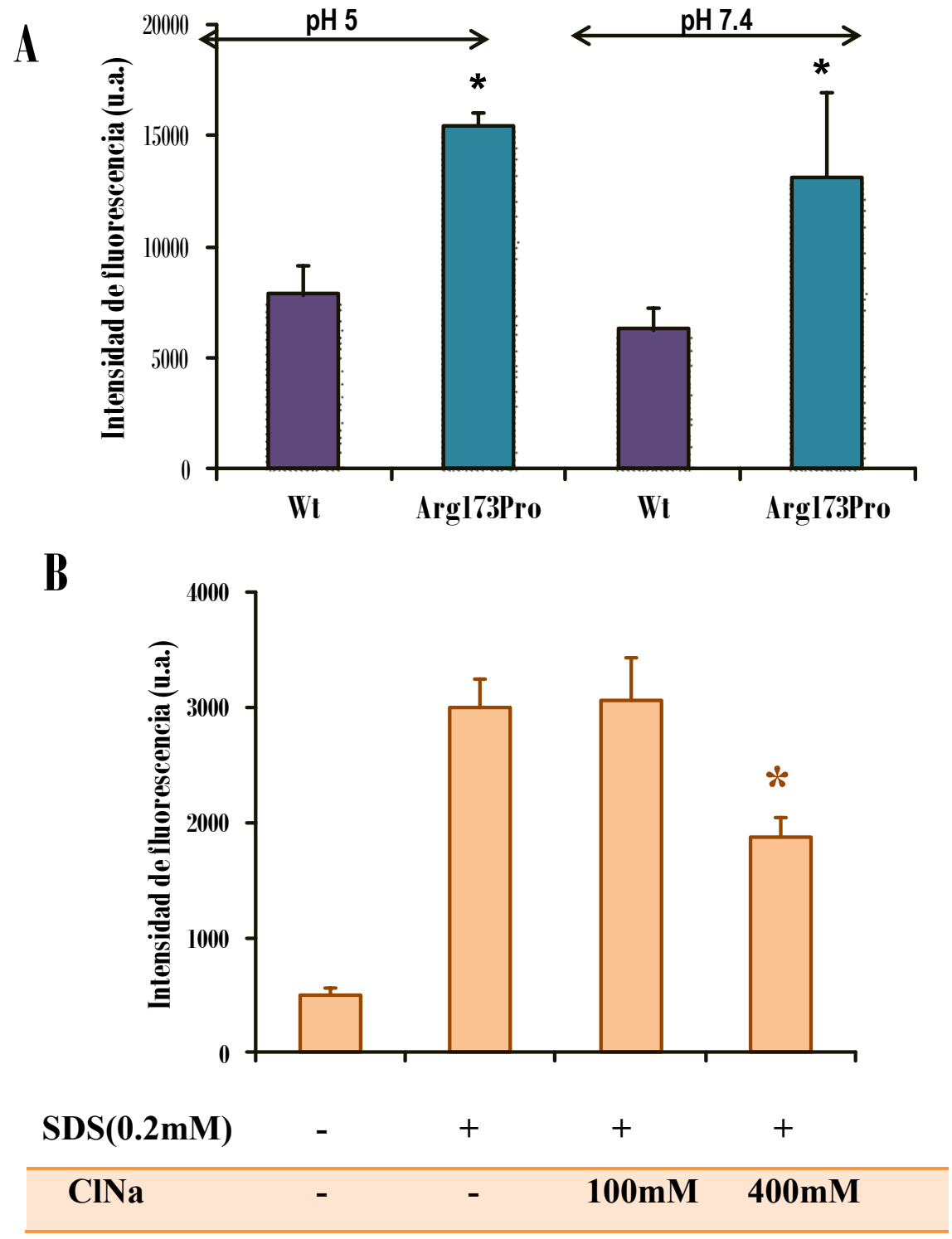

Figura 5.12 Unión de proteínas a SDS. A) Las variantes Wt y Arg173Pro (0,2mg/ml) fueron incubadas (tanto a pH 7,4 0 5) en ausencia 0 en presencia de 0,2mI de SISS. Luego de 48 hs a $37^{\circ} \mathrm{C}$ se agregó ThT en relación molar 1:1 proteína: sonda. Se cuantificó en lector de placa la intensidad de fluorescencia a $480 \mathrm{~nm}$ (excitación a 430nm). Las diferencias estadísticamente significativas entre las condiciones experimentales fueron evaluadas por ANOVA, seguido de test de Tukey. Las Barras corresponden al promedio \pm desviación estándar. Los símbolos * denotan diferencias con respecto a Wt a p<0,01. B) El efecto de la concentración de sal testeado por incubación de Argl73Pro $(0,2 \mathrm{mg} / \mathrm{ml})$ a pH 7,4 en ausencia 0 presencia de $0,2 \mathrm{mVI}$ de SISS más 0, 100 y $400 \mathrm{mV}$ de CINa. La incubación fue realizada como en el punto A. El símbolo “*” denota una diferencia con respecto a la proteína en ausencia de CINa a p <0,01 


\section{Interacción con Heparina}

En el proceso amiloidogénico, se propone también que ligandos del entorno pueden estabilizar las fibrillas amiloides. Este proceso es atribuido en los últimos años a los $\mathrm{GAGs}^{19}$, siendo que la mayoría de los mismos juegan un papel crucial formando parte de las matrices extracelulares y, por lo tanto es factible que interaccionen con las proteínas en el proceso de agregación. Me propuse entonces comprobar el efecto de la heparina como un ligando probable. Resultados obtenidos previamente en el laboratorio demostraron que la forma Wt no interactúa significativamente con heparina a $\mathrm{pH} 7,4^{41}$. Con el fin de comparar este comportamiento con el de la mutante, primero estudiamos la tendencia a la agregación en presencia de este ligando. Se incubaron las proteínas nuevamente a $0,2 \mathrm{mg} / \mathrm{ml}$ durante 48 hs en buffer McIlvaine a $\mathrm{pH}$ 7,4 y 5 con heparina en relación 1:1 heparina: proteína. Posteriormente se agregó ThT en relación 1:1 y se registró la fluorescencia en lector de placa (Figura 5.13) como se explicó en líneas anteriores. Se observa que la variante Arg173Pro se une mayormente a ThT a $\mathrm{pH} 7,4$ pero no a $\mathrm{pH} 5$.

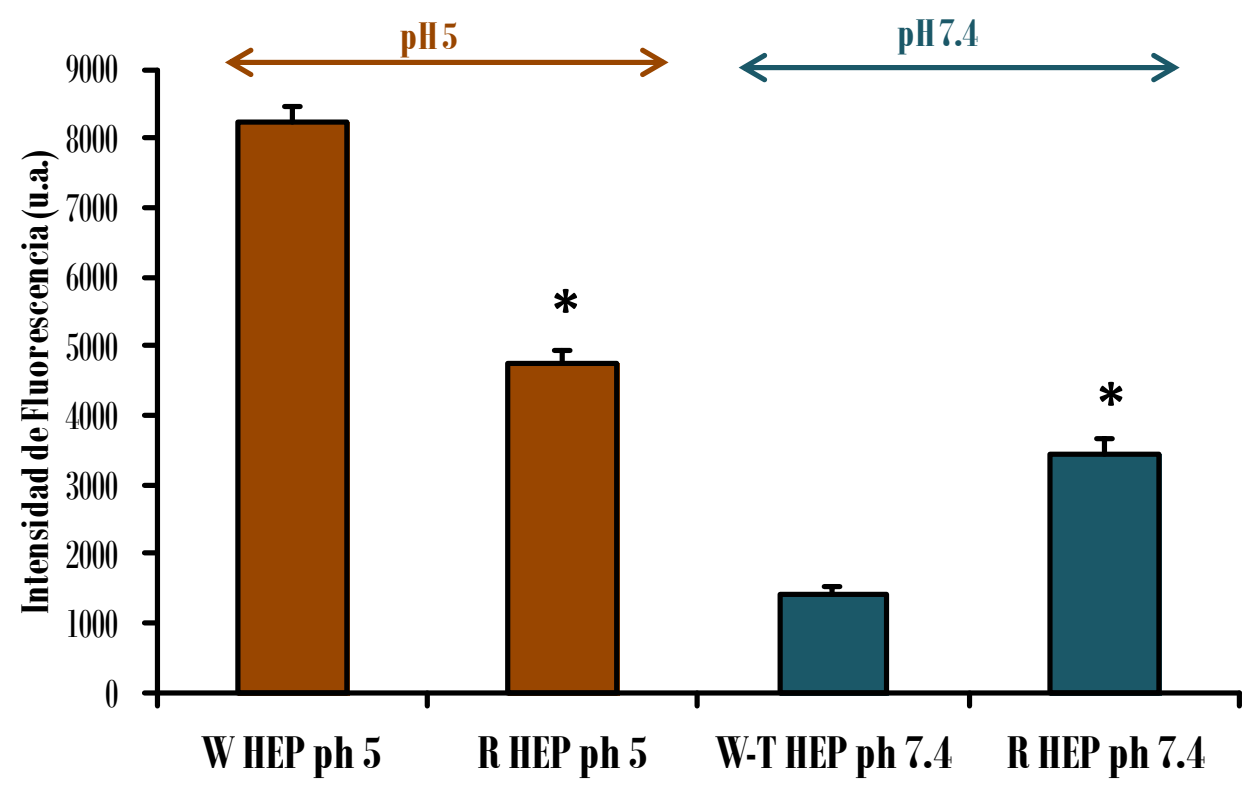

Figura 5.13: Proteínas $\left(0,2 \mathrm{mg} / \mathrm{ml}\right.$ en buffer Mcllvaine, $\mathrm{pH} 5 \mathrm{y}$ pH 7.4 fueron incubados por $48 \mathrm{hs}$ a $37{ }^{\circ} \mathrm{C}$ en presencia 0 en ausencia de heparina en relación molar l:1. La unión a Tioflavina fue medida como se describió arriba. Las Barras corresponden al promedio \pm desviación estándar. Las diferencias estadísticamente significativas entre las condiciones experimentales fueron evaluadas por Test- T Student. El símbolo “*” denota la diferencia con la misma proteína sin heparina a $\mathrm{p}<0,01$.

Debido a la carga negativa de GAGs, la unión a proteínas se espera que sea más eficiente en pH más bajo, ya que la protonación de los residuos de His resulta en un aumento de la carga neta positiva. Se ha confirmado previamente este comportamiento 
con la forma $\mathrm{Wt}^{43}$. Aquí, cuando se incubaron la variante apoA-I Arg173Pro y la forma Wt a pH 5,0, a pesar de que ambas proteínas muestran un alto nivel de unión de ThT, el rendimiento de la fluorescencia fue mayor para Wt que para el mutante Arg173Pro (Figura 5.13). Por otra parte analicé los productos de agregación a través de una electroforesis nativa en gradiente 4\%-25\% (PAGGE) (Figura 5.14).

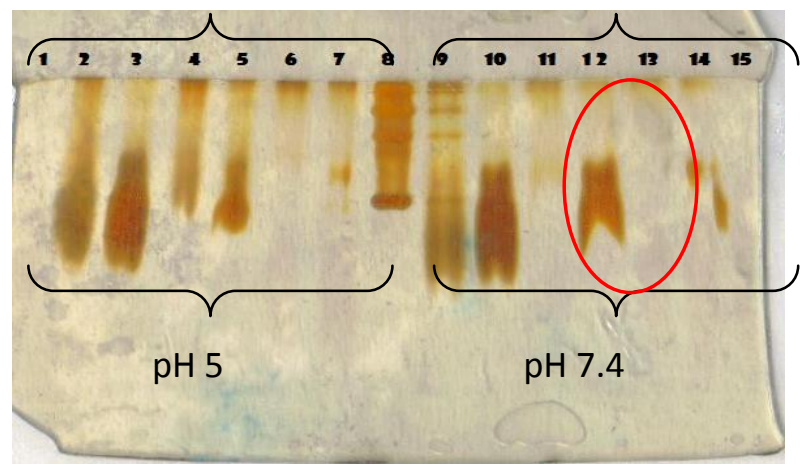

Figura 5.14. Gel nativo en gradiente. Las variantes de Argl73Pro y Wt se incubaron sin y con heparina en distintas relaciones de Heparina: proteína, 0.5:1; 2:1 a pH 5 y 7.4. Posteriormente sembré $12 \mu \mathrm{L}$ de cada una en un gel nativo en gradiente 4-25\%. La calle 8 corresponde al Standard de alto peso molecular $(669,440,232,140$ y 67 klla. Amersham Biosciences, UK) El orden fue el siguiente:

\section{pH 5.0}

Calle 1: Heparina sola

Calle 2: Arg173Pro sola

Calle 3: Wt sola

Calle 4: Arg173Pro + Heparina (Relación0.5:1)

Calle 5: Wt + Heparina (Relación0.5:1)

Calle 6: Arg173Pro + Heparina (Relación2:1)

Calle 7: Wt + Heparina (Relación2:1)

Calle 8: STANDARI
pH 7.4

Calle 9: Arg173Pro sola

Calle 10: Wt sola

Calle 11: Arg173Pro + Heparina (Relación0.5:1)

Calle 12: Wt+ Heparina (Relación0.5:l)

Calle 13: Arg173Pro + Heparina (Relación2:1)

Calle 14: Wt + Heparina (Relación2:1)

Calle 15: Heparina Sola

Como se esperaba (Figura 5.14), los carriles que contienen proteínas sin heparina (carriles 2, 3, 9 y 10) mostraron bandas que migran sobre una posición consistente con el peso molecular esperado para los monómeros. Cuando la forma Wt se incubó en presencia de heparina, la mayoría de la intensidad permanece asociado a esta banda (carril 5 y 12), lo que confirma que no se produce interacción significativa en estas condiciones. Por el contrario, la incubación de la variante Arg173Pro con heparina durante 48 h resulta en la desaparición de la banda de monómero (carril 4 y 11), lo que indica la formación de complejos de mayor tamaño, que probablemente no sean resueltos en este tipo de gel. Dada la relevancia fisiológica a discutir, considero 
especialmente interesante el resultado a pH 7.4 (marcados con un círculo rojo en la Figura 5.14).

Con el fin de obtener una mayor comprensión de este fenómeno, se comparó este producto mediante AFM. En este caso, se pudieron detectar agregados que eran alrededor de $5 \mathrm{~nm}$ de altura, más extendida y más amorfo que las de la proteína en ausencia de heparina (Figuras 5.15A y 5.15B).
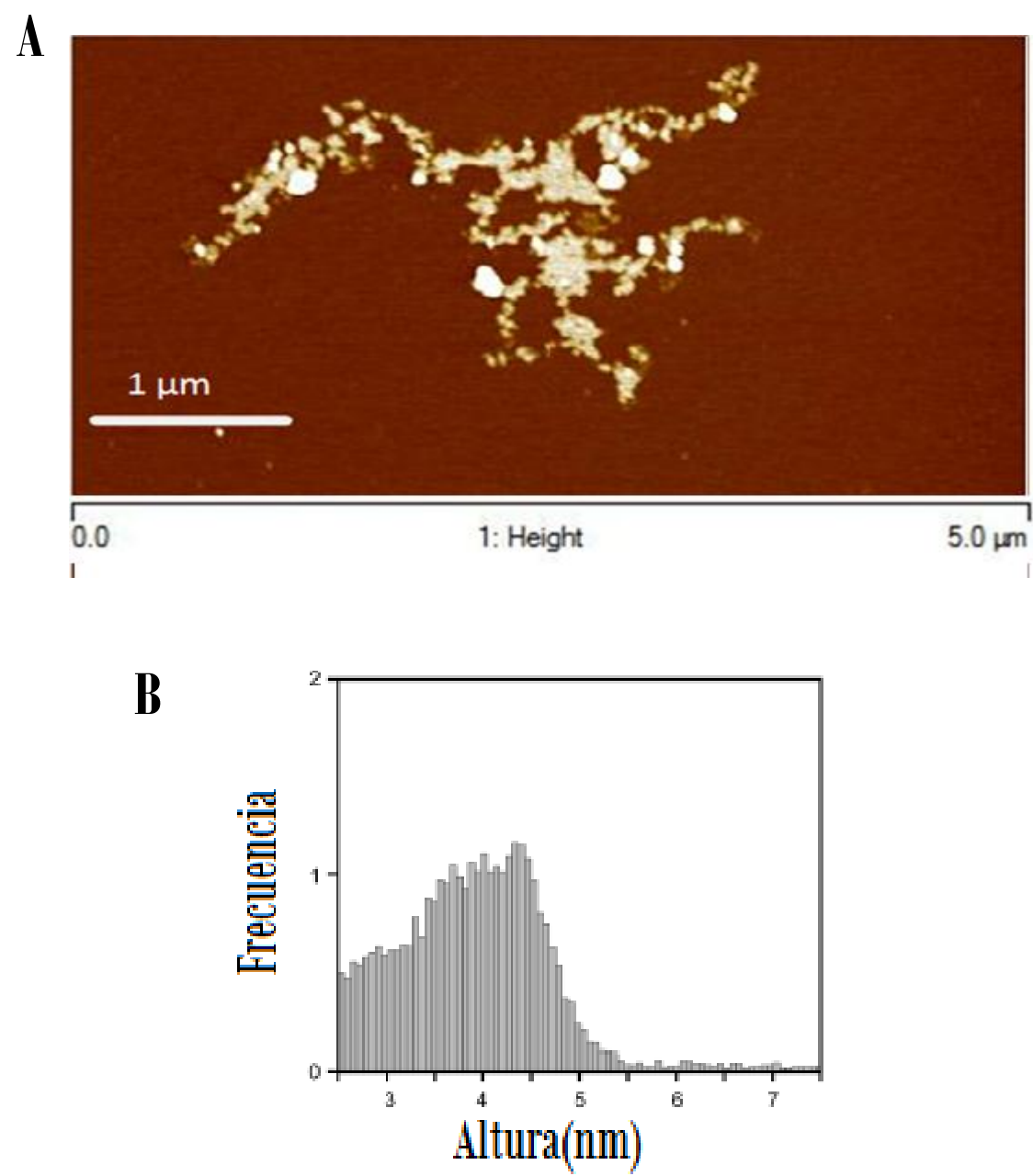

Figura 5.15: Caracterización de la unión de variantes de apo A-I a heparina. A) Caracterización de la morfología de agregados de Arg173Pro con heparina. Análisis de las imágenes observadas con AFM. Proteínas $(0,5 \mathrm{mg} / \mathrm{ml})$ fueron incubadas por 24 hs y montadas en placa de mica. Las barras muestran la escala utilizada en la imagen. B) Distribución de la altura de oligómeros resultante de las medidas en el plano-Z.

\section{F. PROCESAMIENTO PROTEOLÍTICO}

Con el fín de estudiar si la variante en estudio posee una mayor susceptibilidad a la proteólisis incubamos a $37^{\circ} \mathrm{C}, 0.2 \mathrm{mg} / \mathrm{ml}$ de proteínas con metaloproteasa $12 \mathrm{en}$ relación 1000:1 proteína: enzima. Saqué alícuotas a tiempo 0, 15, 30 minutos, 1 y 2 
horas de incubación El producto fue analizado mediante SDS-PAGE. Se observó que la variante apo A-I Arg173Pro exhibe una mayor susceptibilidad a la proteólisis, siendo casi completamente hidrolizada al cabo de 30 minutos mientras que la Wt conserva su peso molecular aun al cabo de 2 horas de incubación (Figura 5.16)

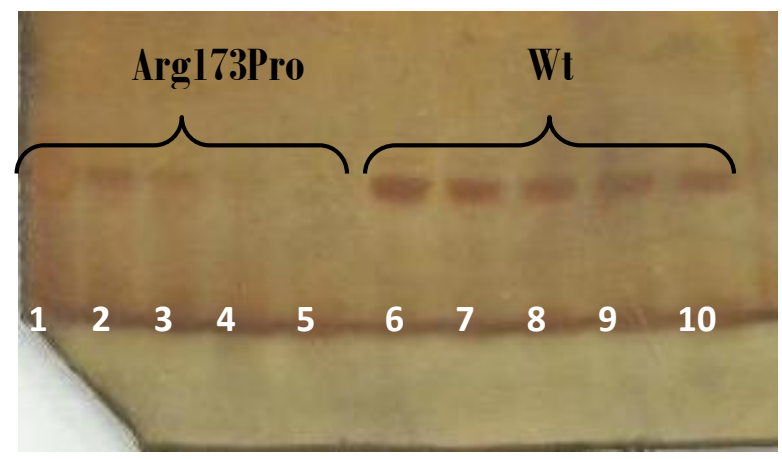

Figura 5.16: Gel SISS-PAGE: Las variantes Arg173Pro y Wt fueron incubadas con MINP 12 en relación proteína: enzima 1000:1. Se extrajeron alícuotas a los 0,15, 30 minutos, 1 y 2 horas. Agregué buffer muestra y sembré $10 \mu \mathrm{L}$ de cada una en un SDS-PAGE. Luego revelé con tinción con nitrato de Plata. El orden fue el siguiente:
1. Arg173Pro 0 min
6. Wt 0 min
2. $\quad$ Argl73Pro $15 \mathrm{~min}$
7. Wt $15 \mathrm{~min}$
3. $\quad \operatorname{Arg} 173$ Pro $30 \mathrm{~min}$
8. Wt $30 \mathrm{~min}$
4. Arg173Pro 1 Hora
9. Wt 1 Hora
5. $\quad \operatorname{Arg} 173$ Pro 2 Horas
10. Wt 2 Horas

A fin de incrementar la sensibilidad de esta determinación, realicé el mismo ensayo de proteólisis revelando mediante western-blot con anticuerpo anti-apoA-I (Figura 5.17)

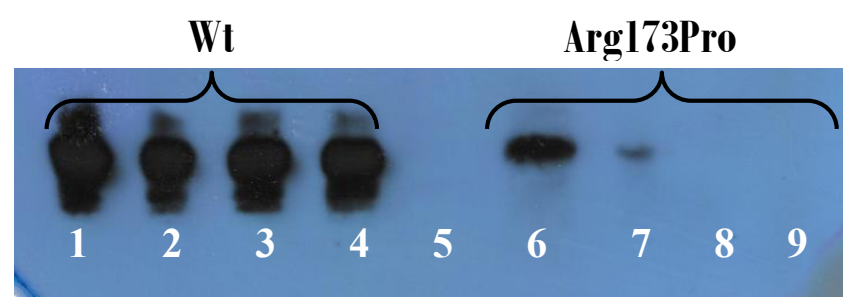

Figura 5.17: Western-Blot: Las variantes Arg173Pro y Wt fueron incubadas con MMP-12 en relación proteína: enzima 1000:1. Se extrajeron alícuotas a los 0,15, 30 minutos y 1 hora. Agregué buffer muestra y sembré $7 \mu \mathrm{L}$ de cada una en un SIDS-PAGE. Luego realicé el western-blot. Los títulos de anticuerpos utilizados fueron: Anticuerpo primario Anti-Apo AI 1:50000 y secundario Anti IgG de conejo l: 5000. El orden es el siguiente:
1. Wt 0 min
6. $\operatorname{Arg} 173 P r 00 \mathrm{~min}$
2. Wt $15 \mathrm{~min}$
7. $\operatorname{Arg} 173 P r 015 \mathrm{~min}$
3. $\quad$ Wt $30 \mathrm{~min}$
8. Argl73Pro $30 \mathrm{~min}$
4. Wt l Hora
9. Argl73Pro l hora
5. Rainbow (no se visualiza en el revelado) 
En un ensayo similar, comparé la susceptibilidad relativa de ambas variantes ante la digestión con tripsina, variando en este caso la relación proteína: enzima y manteniendo constante el tiempo de incubación. En concordancia con el ensayo anterior observé que la variante Arg173Pro posee mayor susceptibilidad a la proteólisis comparado al Wt en todas las concentraciones ensayadas. (Figura 5.18)

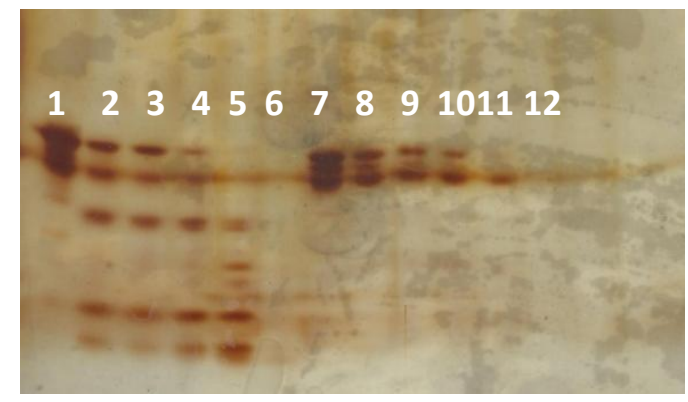

Figura 5.18: Gel SDS-PAGE: Las variantes Arg173Pro y Wt fueron incubadas con Tripsina en relación proteína: enzima 1000:1, 750:1, 500:1, 250:1 y 100:1. Se extrajeron alícuotas a los 15 minutos. Agregué buffer muestra y sembré $15 \mu \mathrm{L}$ de cada una en un SDS-PAGE. Luego revelé con tinción con nitrato de Plata. El orden fue el siguiente:
1. Argl73Pro sola
7. Wt sola
2. Arg173Pro +tripsina 1000:1
8. $\quad$ Wt +tripsina 1000:1
3. $\quad$ Arg173Pro +tripsina 750:1
9. Wt +tripsina $750: 1$
4. $\quad$ Arg 173Pro +tripsina 500:1
10. Wt +tripsina $500: 1$
5. $\quad \operatorname{Arg} 173$ Pro +tripsina 250:1
11. Wt +tripsina 250:1
6. $\operatorname{Arg} 173 P$ ro +tripsina 100:1
12. Wt+tripsina 100:1

\section{G. ACTIVACIÓN DE MACRÓFAGOS HUMANOS}

Para determinar si las variantes de apoA-I son capaces activar a los macrófagos y así inducir una respuesta del tipo inflamatoria, ensayamos la producción de citocinas, TNF- $\alpha$ e IL-1 en la línea celular de monocitos humanos THP. Luego de ser diferenciadas a macrófagos s las células fueron incubadas con proteínas en a $5 \mu \mathrm{g} / \mathrm{ml}$ durante 3 hs. Se extrajo el sobrenadante y se realizó un ELISA para TNF- $\alpha$ e IL-1ß. Como la Figura 5.19 indica claramente, se evidenció una mayor liberación de IL-1ß (Figura 5.19 A) y TNF- $\alpha$ (Figura 5.19 B) en las células THP ${ }_{1}$ incubadas con la variante Arg173Pro comparado al Wt. Esto podría ser clave para perpetuar un microambiente proinflamatorio que incremente el daño local del órgano afectado. 

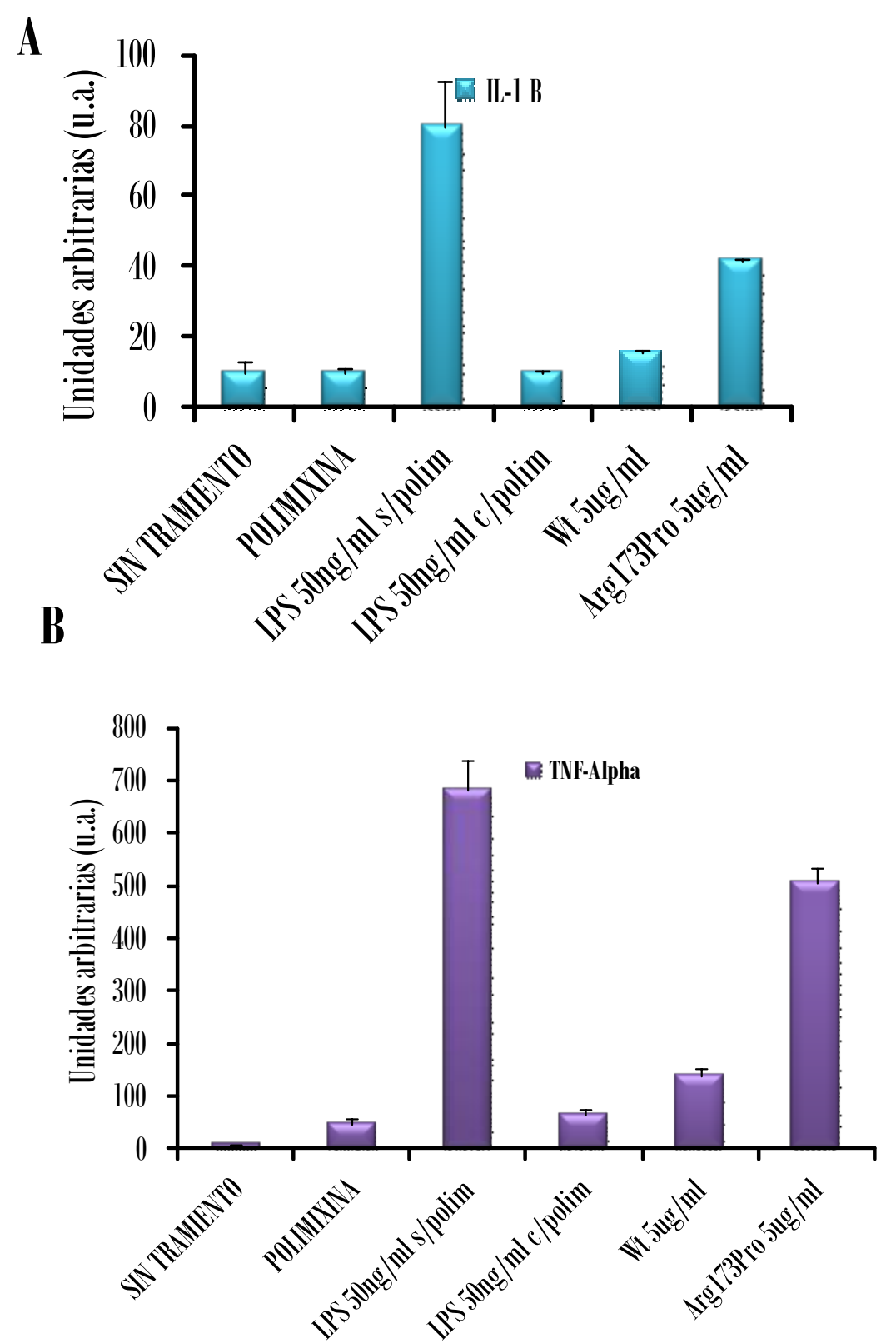

Figura 5.19: Efecto de las variantes de apoA-I sobre la activación pro-inflamatoria de macrólagos. Células THP-l fueron diferenciadas a macrófagos e incubadas con apoA-I Wt y Arg173Pro en una concentración de $5 \mu \mathrm{g} / \mathrm{ml}$ en presencia de 50 $\mu \mathrm{g} / \mathrm{ml}$ de polimixina B. La polimixina se utilizó como agente secuestrante del LPS que pueda estar presente como contaminante del proceso de purificación de las variantes a partir de bacterias. LPS, en $1 \mu \mathrm{g} / \mathrm{ml}$, en ausencia y en presencia de polimixina (LPS) se usó como control positivo y negativo respectivamente de la activación. A) La producción de IL-lB y B) de TNF- $\alpha$ se determinó por ELISA de los sobrenadanates luego de incubar las células durante 3 horas con los distintos tratamientos.

\section{H. ENSAYOS CON POLÍMEROS SINTÉTICOS COMO MODELO DE MATRIZ}

Con el fín de evaluar la interacción de ligandos sulfatados con apoA-I, nos dispusimos a construir polímeros sintéticos de HEMA y SSNa en 2 relaciones molares 
distintas. Los mismos se obtuvieron por polimerización radical como fue explicado en materiales y métodos.

La micrografía electrónica de barrido (Realizado en el departamento de polímeros, Facultad de Ciencias Químicas, Universidad de Concepción, Chile) nos muestra la imagen de ambas matrices obtenidas (Figura 5.20). La nomenclatura utilizada para nombrar las matrices corresponde a la fracción de SSNa, siendo 0,75 ó 0,25. Los geles que contienen menor cantidad de SSNa (es decir, carga negativa más baja) muestran una superficie más lisa con cavidades de diámetros diferentes (Figura 5.20A y B). En cambio, el enriquecimiento en SSNa a 0,75 relación molar respecto de HEMA, da lugar a una superficie puntiaguda con una topología más regular (Figura 5.20 C y D).
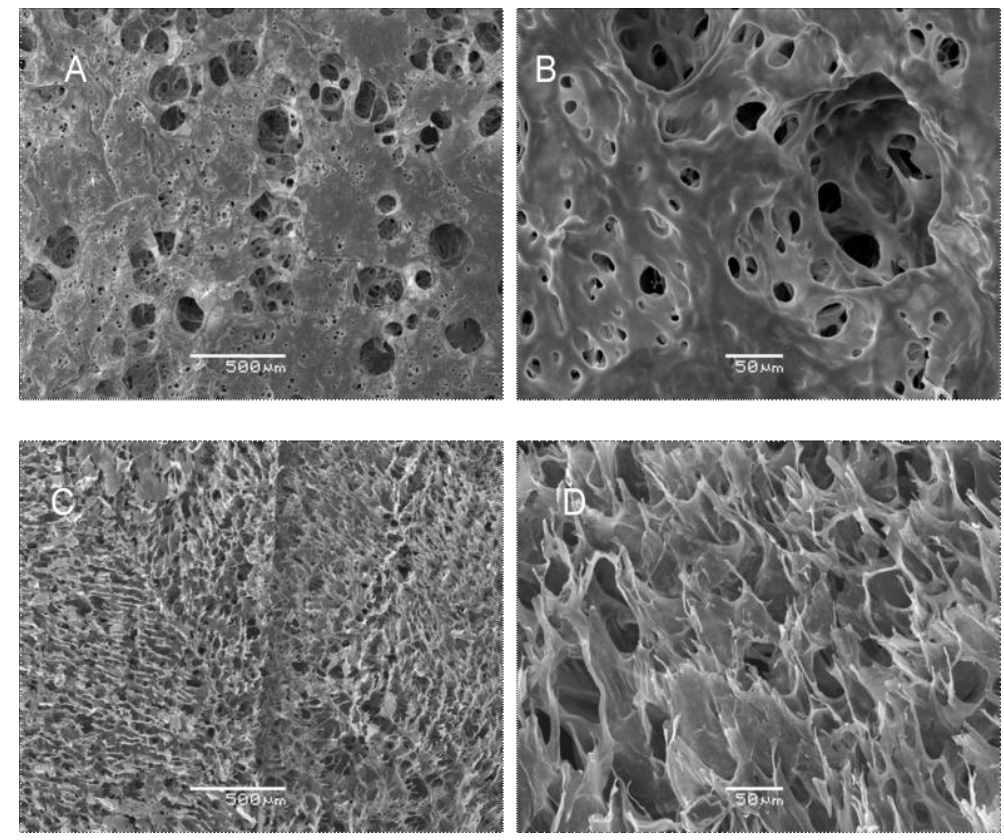

Figura 5.20 0bservación de los hidrogeles por microscopía electrónica de barrido (SEM). El copolímero P (SSNa-co-HENA) que contenta fracciones de 0,25 (A y B) 0 0,75 SSNa (C Y D). Las barras blancas en cada figura indican la escala de medida utilizada en cada caso.

\section{Interacción apoA-I con matrices}

\section{- A través de ensayos de fluorescencia}

A continuación, nos propusimos determinar si existe una unión diferencial de apoA-I a las matrices que tienen diferentes relaciones de SSNa a HEMA. La proteína Wt marcada con $\mathrm{DNCl}$ se incubó con matrices y la cantidad de proteína unida se determinó cuantificando la fluorescencia asociada a la matriz y en el sobrenadante después de la centrifugación para separar la proteína no unida. La Figura 5.21 muestra 
que aproximadamente el $42 \%$ de la proteína permanece asociada a la matriz 0,75 , mientras que sólo el 19\% apareció unido en el 0,25.

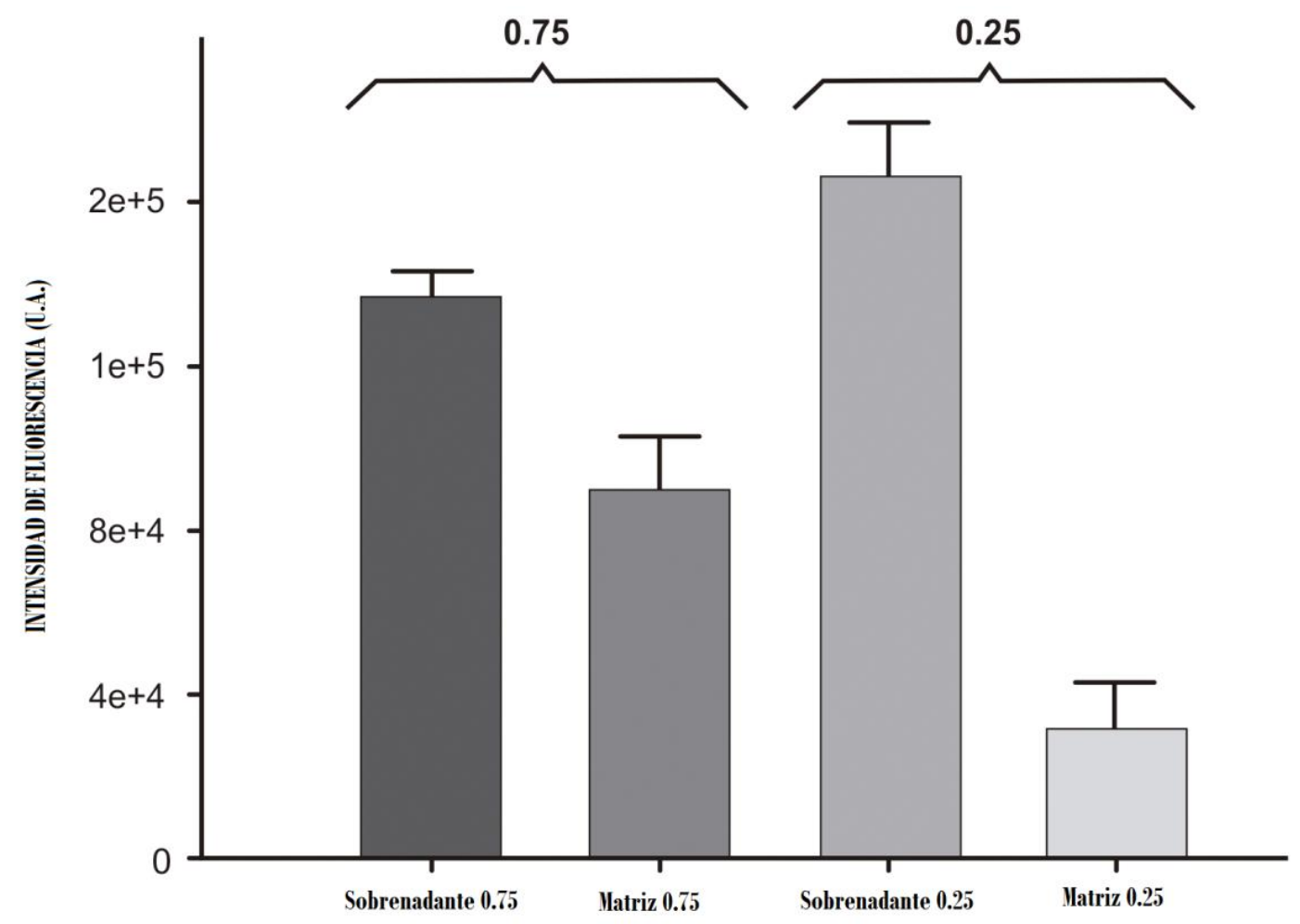

Figura 5.21: Cuantificación de la unión de apoA-I marcada con INCl a matrices. 0,05 g de las diferentes matrices se incubaron con apoA-I DNS-Cl. Se separó el sobrenadante y la matriz y se llevó al volumen original con buffer. Cada una de ambas fracciones se colocó en una placa de fluorescencia oscura y se midió la fluorescencia asociada a DNCl con filtros de excitación y emisión de 360 nm y 535, respectivamente.

\section{- A través de microscopia confocal}

Se prepararon 3 cubetas dobles como las que se muestran en la Figura 5.22, en las que se colocó un disco de cada polímero de espesor controlado.

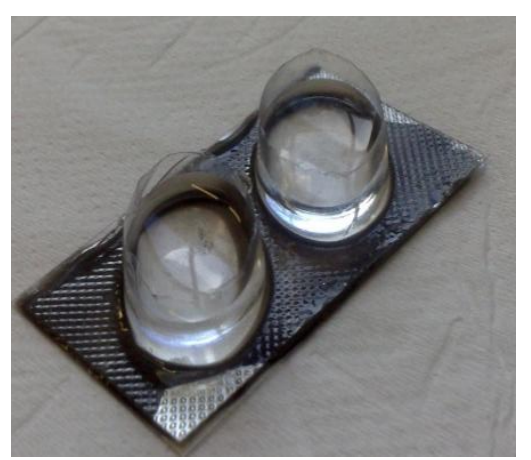

Figura 5.22: Cubeta casera realizada con blíster de antibiótico, pegada sobre los portaobjetos del microscopio confocal. El pegamento utilizado no absorbía luz, de modo que no interfirió con el ensayo realizado. 
Se incubaron los geles durante $48 \mathrm{hs}$ a $37^{\circ} \mathrm{C}$ en presencia de Wt ó Arg173Pro (1,13 uM en buffer Tris a pH 7.4) marcadas con FITC. Se eliminó el exceso de proteína no unida y se lavó 3 veces con buffer.

A fin de cuantificar la fluorescencia absorbida a los polímeros, se utilizó un microscopio confocal espectral bifotónico, perteneciente al centro de Microscopía avanzada (CMA) de Bío-Bío. Universidad de Concepción, Chile. Se registró consecutivamente una medición de 100 imágenes, cada 9 um a lo largo del eje $z$ excitando a $488 \mathrm{~nm}$ y detectando emisión a $512 \mathrm{~nm}$ +/- 20 um medidas a temperatura ambiente. La intensidad asociada a estas imágenes es integrada por el software asociado al microscopio, obteniendo que la intensidad total de la Wt asociada a la matriz 0,75 es mayor que la intensidad asociada a 0,25 (Figura 5.23 A 1 vs 2). Además, de manera interesante, la intensidad asociada a ambas matrices $(0,75$ y 0,25$)$ es mayor cuando se incuban con Arg173Pro (Figura 5.23A 1 vs 3 y 2 vs 4 respectivamente). Estas intensidades relativas están representadas en la Figura 5.23B.
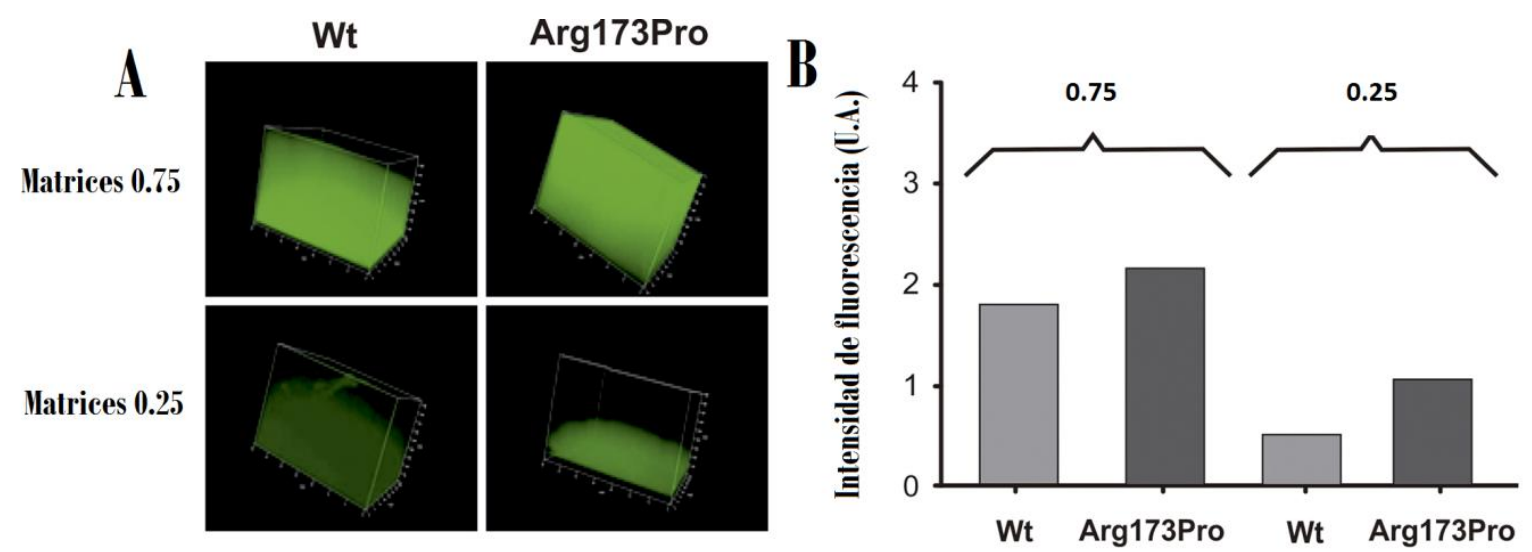

Figura 5.23: Caracterización de las imágenes 3-I de la unión de apoA-I a las matrices A) integración de 100 imágenes de florescencia obtenidas mediante el escaneo en el eje z en el microscopio. B) valor relativo de la intensidad de fluorescencia asociada a los hidrogeles obtenidos por el software Image-J. Las imágenes se tomaron a temperatura ambiente, con excitación a $488 \mathrm{~nm}$ y emisión a $512 \mathrm{~m}+/-20 \mathrm{~nm}$. Se adquirió una pila de 100 imágenes cada $9 \mu \mathrm{m}$

\section{Interacción de proteínas con monómeros de la matriz}

Finalmente, se evaluó la posibilidad de que la unión relativa de las proteínas a las matrices pueda deberse a alteraciones estructurales como consecuencia de su unión a los monómeros, lo que pueda favorecer la retención y / o agregación de proteínas. Por lo tanto, Arg173Pro se incubó con un exceso de monómeros (SSNa o HEMA) y se utilizaron medidas biofísicas para caracterizar su estructura. Los espectros de fluorescencia intrínseca de Trp de apoA-I permanecen similares en presencia de 
monómeros (no mostrado). El reordenamiento espacial de la proteína inspeccionado mediante su unión a Bis ANS no se alteró significativamente ya que no se detectó ni un aumento de intensidad significativo ni un cambio del centro de masa en los espectros en presencia de los monómeros SSNA o HEMA (Figura 5.24)

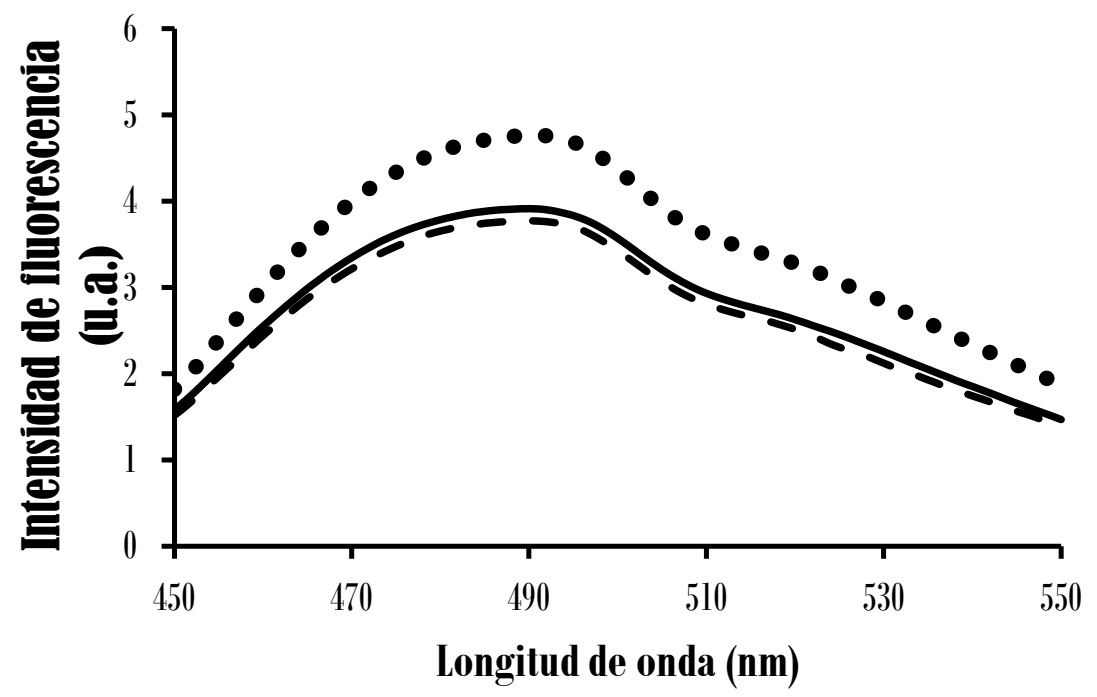

Figura 5.24 Argl73Pro $\left(0,2 \mathrm{mg} / \mathrm{ml}\right.$ en Mcilvaine, pH 7,4) se incubó durante 48 hs a $37^{\circ} \mathrm{C}$ y se añadió Bis ANS a una relación molar de sonda l: 1 a proteína. Se adquirieron espectros con excitación a 395 y emisiones registradas entre 450 y $550 \mathrm{~nm}$; Las líneas negras, punteadas y discontinuas corresponden a proteínas en ausencia o la presencia de 0,5 mII de HEMA o SSNa, respectivamente. La diferencia en intensidades o corrimiento entre espectros no resultó significativa.

Se analizó a continuación la fluorescencia correspondiente a ThT para detectar si la interacción de la proteína con los monómeros podría inducir un plegamiento anómalo. Cuando Arg173Pro se incubó a pH fisiológico, una clara baja unión a ThT indica la tendencia de la proteína a formar estructuras que podrían ser sensibles a los agregados. Esta fluorescencia no se incrementa en presencia de monómeros, lo que indica que los grupos polares de los monómeros no provocan la tendencia a la agregación de esta variante. (Figura 5.25). 


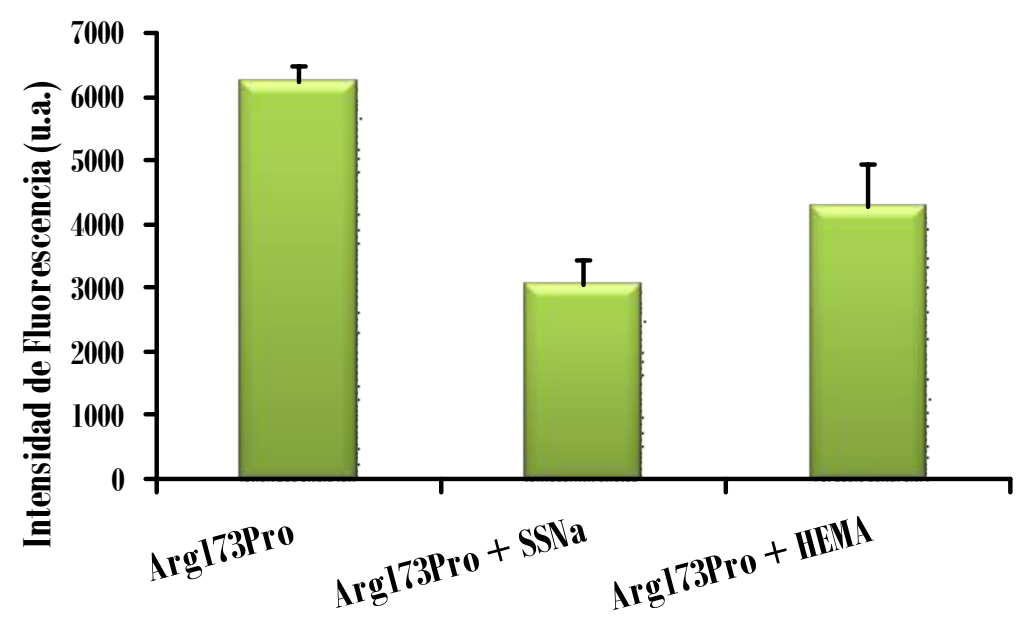

Figura 5.25 La agregación de tipo amiloide se detectó mediante la adición de ThT a Arg173Pro a una relación molar de 1: 1 con respecto a la proteína. Después de 48 horas de incubación a $37^{\circ} \mathrm{C}$, se cuantificó la fluorescencia en el lector de microplacas a $480 \mathrm{~nm}$ (excitación establecida a $430 \mathrm{~nm}$ ). Las barras corresponden a las medias \pm SE.

Por último, se probó si los monómeros podrían competir (y / o inhibir), la unión de Arg173Pro a la heparina. Para probar esta posibilidad, incubamos el mutante con heparina y comparamos su migración con la electroforesis nativa de PAGGE en presencia de cada monómero. Se detectó una unión eficaz de proteína-heparina cuando la banda correspondiente a la proteína libre de lípidos (Carril 1 en la Figura 5.26) se desvanece dando lugar a bandas de mayor tamaño, probablemente debido a la formación de complejos Proteína-GAGs (carriles 2 y 4). Estas estructuras permanecen estables incluso cuando se incuban en presencia de SSNa (Carril 5) o HEMA (Carril 6), indicado por la ausencia de banda correspondiente a la proteína libre.

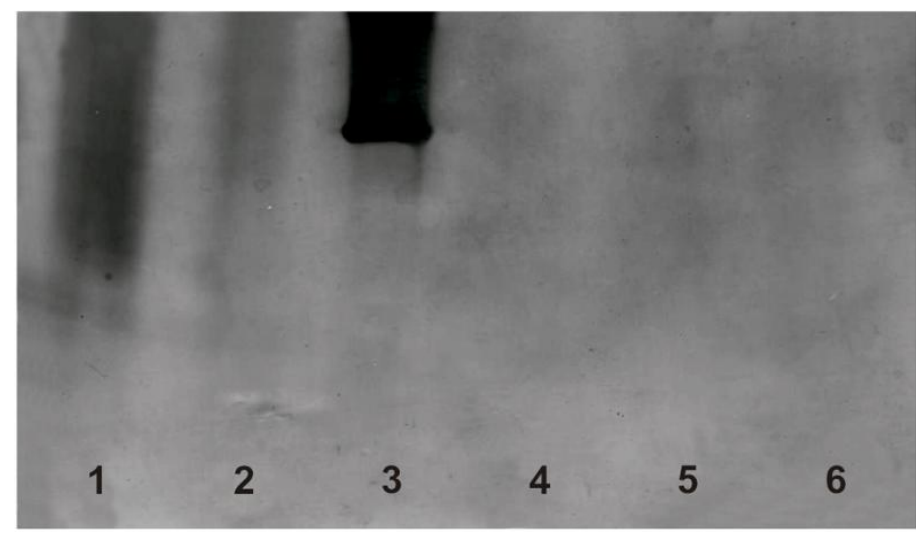

Figura 5.26. Gel PAGE nativo en gradiente 4-25\% revelado por tinción con Nitrato de plata. A fin de contar con un control de peso molecular, se sembró albúmina como Standard (peso molecular 66 kD), en el carril 3. Arg173Pro se incubó como se indica más arriba sin (carril l) 0 con heparina en relaciones molares heparina: proteína 2 y 10: 1, carriles 2 y 4, respectivamente); Arg173Pro y heparina en la última relación molar se incubaron bajo la misma condición en presencia de 0,5 mIl de SSNa (carril 5) o HENA solo (carril 6) 


\section{DISCUSIÓN}

La apoA-I cumple un gran rol en el organismo al intervenir en el transporte reverso de colesterol; así, formando parte de las partículas HDL, posee la capacidad de interaccionar con muchísimos receptores celulares, promoviendo la captación de colesterol, el que posteriormente es conducido al hígado para su excreción. Su gran versatilidad estructural es la que permite llevar a cabo dicha función e interaccionar con una gran variedad de ligandos; por otra parte esta característica beneficiosa puede ser perjudicial cuando la misma sufre mutaciones que afectan su plegamiento normal haciéndola más propensa a la agregación y depósito en distintos tejidos causando amiloidosis. Además, fue descripto que la proteína en su secuencia nativa también se deposita de manera difusa como agregados amiloides en placas ateroscleróticas ${ }^{37,84}$, lo cual nos permite deducir que no sólo las mutaciones influyen en el cambio estructural, sino que también cambios sutiles en el entorno, como por ejemplo un ambiente pro inflamatorio podría desencadenar la patogenia. De hecho, se ha postulado el desarrollo de citotoxicidad debido a algunas variantes de apoA-I asociadas a amiloidosis, lo que soporta las hipótesis de que no sólo corresponde a una patología debida a pérdida de función, sino también al inicio de eventos debidos a daño celular inducido por proteínas mal plegadas.

Con el objetivo de profundizar los conocimientos acerca de la amiloidosis inducida por esta proteína y dilucidar además las consecuencias de su interacción con ligandos y la probable respuesta citotóxica, desarrollamos este trabajo, eligiendo en principio una variante de apoA-I identificada en pacientes con amiloidosis, Arg173Pro, y explorando su agregación en distintas condiciones, como así también el producto ante un ambiente pro inflamatorio. Aunque trabajos previos de nuestro laboratorio demostraron que la proteína Wt posee una tendencia intrínseca a la agregación ${ }^{41,43}$, bajo las condiciones ensayadas en el diseño experimental propuesto, la misma se emplea como control adecuado en base a las alteraciones que los mutantes pueden evidenciar en relación a su comportamiento.

\section{A. ESTABILIDAD, CONFORMACIÓN PROTEICA Y TENDENCIA A LA AGREGACIÓN}

Para muchas proteínas amiloidogénicas, la desestabilización del estado globular nativo por mutaciones o por la modificación del entorno está altamente correlacionado 
con una conformación fibrilar, lo que sugiere que la alteración del plegamiento nativo es el evento principal para desarrollar la amiloidogénesis ${ }^{73,85,86}$. Sin embargo, el sorprendente hecho de que los mutantes de transtirretina (TTR) más inestables, Asp18Gly y Ala25Thr, no son los más patógenos ${ }^{87}$, indica que la correlación propuesta entre la estabilidad y la patogenicidad no debe ser tomado como una condición sine qua non. Por ello, nos dispusimos a determinar en primer término si existe correlación entre la tendencia al plegamiento anómalo de Arg173Pro y su estabilidad.

Los ensayos de desnaturalización química con concentraciones crecientes de Gnd-HCl a pH fisiológico mostraron una menor estabilidad comparado a Wt, incluso el perfil de exposición de residuos Trp no respondió al modelo de dos estados. Si bien la proteína nativa posee una estructura flexible, la variante Arg173Pro fácilmente pierde esta conformación frente a un agente caotrópico. La pérdida de esta estructura secundaria también fue evidenciada por CD en el UV lejano, lo que podría contribuir al menos en parte a la mayor tendencia a la agregación de este mutante. El desplazamiento hacia el rojo de la fluorescencia de Trp del mutante Arg173Pro inclusive a bajas concentraciones de guanidina, y una mayor susceptibilidad al quenching de la fluorescencia de estos residuos, evidenciado por una mayor constante de Stern Volmer, indican que el N-terminal de la apoA-I (que tiene en promedio cuatro Trp), está más expuesto al disolvente en el mutante. Además, la titulación con Bis-ANS muestra una mayor intensidad de fluorescencia de la variante respecto a la proteína $\mathrm{Wt}$, evidenciando así un cambio conformacional que resulta en una mayor exposición de la superficie hidrofóbica o una estructura más laxa que permite mayor permeabilidad de la sonda. Gursky y colaboradores propusieron que tanto en la conformación en forma de monómero como de dímero, la estructura de la apoA-I nativa libre de lípidos, se estabiliza mediante dos haces de cuatro segmentos simétricos relacionados en los extremos opuestos. Sugirieron que las mutaciones amiloides naturales (que comprenden especialmente los residuos 44-120 y 154-184) se producen en posiciones clave de la alfa hélice que interrumpen esta disposición ${ }^{39}$. Estos autores sugieren que la introducción de un residuo Pro en lugar de una Arg en la posición 173 puede inducir un quiebre en la repetición 7 de la secuencia helicoidal (residuos Pro165-Gly185), lo cual desorganizaría las interacciones entre este segmento con el yuxtapuesto de las repeticiones 2 y 3 (figura $2.5)^{39}$.

Si fuera así, podríamos suponer que el Trp 72 (en la hélice 2) podría ser desviado de la estructura nativa en la proteína, siendo más susceptible a su vez a la 
proteólisis o más expuesto al micro ambiente. La tendencia del extremo $\mathrm{N}$-terminal para formar estructuras amiloides fue antes $\operatorname{descripta}^{88} \mathrm{y}$, además, el Trp 72 está comprendido en uno de las cuatro "hot-spot" predichas en la apoA-I mediante la aplicación de programa AMYLPRED2 (péptidos 14-22, 53-58, 69-72 y 227-232) ${ }^{89}$.

Por otra parte, el mutante Arg173Pro incubado a tiempos cortos, a bajas concentraciones mostró una mayor unión a ThT comparado a $\mathrm{Wt}$, lo que sugiere que esta variante posee per se una tendencia intrínseca a la agregación. Esto además, fue caracterizado por ensayos de AFM, en los que se observa que la incubación de esta proteína, incluso a bajas concentraciones y $\mathrm{pH}$ fisiológico resultó en la formación de agregados de tamaño heterogéneo y estructuras alargadas (figura 5.7A). Bajo estas condiciones no fue evidenciada la presencia de fibras amiloides. Es interesante notar que este tipo de formaciones fibrilares pueden ser obtenidas, utilizando condiciones de incubación más drásticas (temperaturas altas, presión, agitación, tiempos de incubación etc.). A fin de corroborar la sensibilidad de nuestra metodología para detectar conformaciones fibrilares, incubamos Arg173Pro a 0,4mg/ml pH 7,4 durante 45 días a temperatura ambiente y analizamos la morfología mediante microscopía electrónica (Figura 6.1), detectando en ese caso alto rendimiento de estructuras fibrilares elongadas, aproximadamente de 4-10 $\mathrm{nm}$ de ancho e incluso ligeramente enroscadas en algunos puntos, lo que es característico de fibras amiloides. Sin embargo, la vida media corta de esta proteína (3-5 días) en circulación a concentraciones de apoA-I libre menores a 0.1 $\mathrm{mg} / \mathrm{dl}$, indica que esta conformación no es alcanzada en condiciones físiológicas.

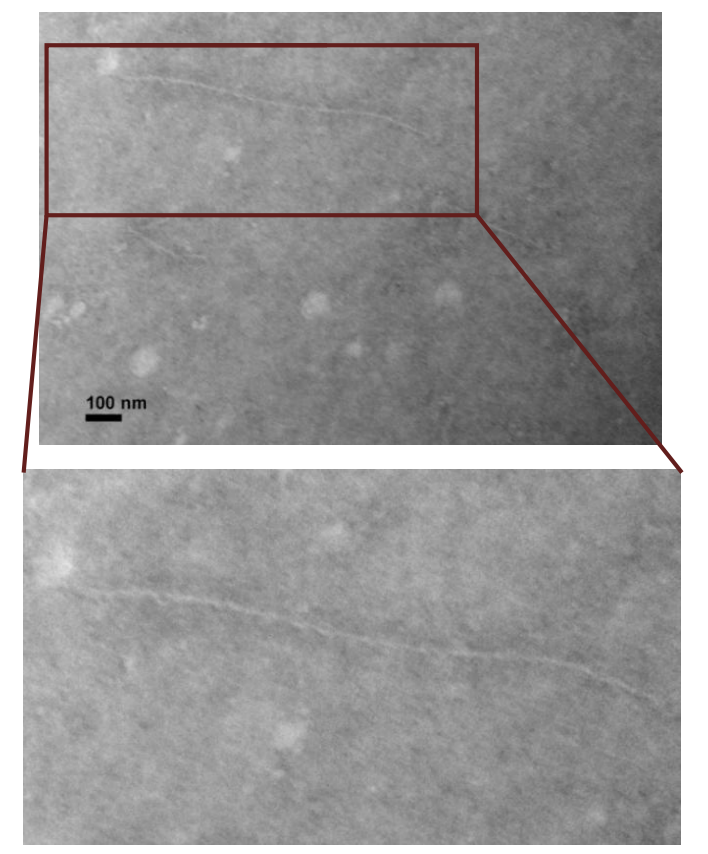

Figura 6.1: Microscopia electrónica de transmisión de muestras de apo A-I Arg173Proincubadas a $37^{\circ} \mathrm{C}$ 0,4 mg/ml, pH 7.4 durante 45 días.

El recuadro representa la estructura magnificada, permitiendo así observar con mayor detalle la fibrilla formada. 


\section{B. EFECTO DEL PH SOBRE LA ESTRUCTURA DE LA PROTEÍNA, LA ESTABILIDAD Y LA PROPENSIÓN A LA AGREGACIÓN}

La incubación en tiempos cortos de las variantes de apo a $\mathrm{pH}$ acídico no indujo un cambio estructural sensible, según fuera analizado mediante los ensayos de desnaturalización con Gnd-HCl, así como de CD en el UV lejano, es decir que este cambio no contribuyó a la inestabilidad ni al plegamiento anómalo de la Arg173Pro. Sin embargo cambios en la fluorescencia en promedio de los Trp (un aumento en el quenching con acrilamida y en la eficiencia de transferencia de energía al Bis-ANS a menor $\mathrm{pH}$ comparado con la variante nativa) indican que el descenso de $\mathrm{pH}$ induce una leve alteración de la estructura secundaria de esta variante; por lo expuesto anteriormente, la existencia de múltiples Trp no permite concluir en los cambios locales de cada residuo. Así el aumento de FRET observado a $\mathrm{pH} 5.0$ puede tener distintas contribuciones: 1) Los Trp al estar más expuestos emitirían a longitudes de onda mayores, con lo cual el espectro de emisión del donor podría solaparse con el de excitación del Bis-ANS ; 2) Si la disposición conformacional que adquieren estos grupos genera más bolsillos hidrofóbicos, resultaría en mayor unión al Bis-ANS ; 3) si en estos bolsillos se encuentran más próximos los Trp habría una mayor cercanía para que se produzca el FRET. El hecho de que la relación Bis-ANS /Trp sea similar en ambas situaciones pareciera excluir la generación de distintos bolsillos hidrofóbicos; sería interesante, y es un proyecto a futuro el construir variantes conteniendo un solo Trp en cada posición de los presentes en la secuencia primaria y, luego de caracterizar su fluorescencia analizando el comportamiento de cada uno para obtener información local detallada. Finalmente, el ligero cambio estructural observado a $\mathrm{pH}$ 5,0 no pareciera tener una influencia significativa sobre el plegamiento anómalo, dado que la fluorescencia de ThT asociada a Arg173Pro fue aproximadamente 2,5-3 veces más alta que la observada a $\mathrm{pH} 7,4$, que es similar a la relación medida para la proteína Wt en las mismas condiciones.

\section{PROPIEDADES DE UNIÓN A LÍPIDOS DE LAS VARIANTES}

La sustitución de una Arg por un residuo Pro se produce en uno de los denominados dominios "hot-spot" de apoA-I, en los que se detectan la mayoría de las 
mutaciones naturales. Esto significa que la perturbación de este dominio debe tener un efecto drástico en la función de la proteína o el metabolismo. La hélice en la que la mutación ocurre se asocia con la unión a lípidos y la actividad de la lecitin-colesterol aciltransferasa (LCAT) ${ }^{35}$. El ensayo de aclaramiento de DMPC indica una incapacidad de la proteína para solubilizar eficazmente lípidos de una bicapa, lo cual está en concordancia con el hecho de que los niveles de colesterol de HDL de pacientes heterocigotos para la mutación son bajos ${ }^{29}$. Así, la consecuencia de la disminución en la eficiencia de lipidación podría ser no sólo una pérdida de la función de la proteína sino además, podría resultar en una cantidad de apo libre relativamente mayor, la que es más sensible a ser modificada en el micro entorno.

\section{PROCESAMIENTO PROTEOLÍTICO}

Los resultados obtenidos en cuanto a la proteólisis de apoA-I indican que la variante Arg173Pro posee una mayor susceptibilidad a ser clivada por parte de metaloproteasa 12 y tripsina. Si bien estas dos enzimas no tienen una especificidad de clivaje, el hecho de que la variante mutada sea degradada casi completamente en pocas horas, sugiere que en un entorno pro-inflamatorio, su procesamiento proteolítico puede resultar en una pérdida de proteína funcional; pero más aún, dada la observación de un péptido N-terminal de la apo en las lesiones de pacientes, es de considerar que el procesamiento proteolítico pueda resultar en la formación de péptidos que sean más citotóxicos o amiloidogénicos que la proteína completa; si bien al momento no encontramos que los productos obtenidos de la proteólisis tuvieran mayor tendencia a la agregación, considero que esta línea de estudio debe ser profundizada. Por otra parte es altamente interesante la estimulación de respuestas celulares de esta variante; el hecho de que Arg173Pro sea capaz de estimular por parte de macrófagos la liberación de IL-1ß y TNF- $\alpha$ nos indica que pequeños cambios conformacionales pueden per se perpetuar un mecanismo pro inflamatorio, lo cual puede en cierta forma conducir a un aumento de la amiloidogenicidad de la variante. El estudio de este campo es sin duda altamente complejo e implica un gran desafío. El conocimiento por ejemplo de cómo el organismo se defiende de las fibrillas amiloides depositadas es una cuestión que hace muchos años se estudia, y nuevas perspectivas plantean un ataque por parte de los neutrófilos a través de un mecanismo de defensa conocido como netosis ${ }^{90}$. Será por tanto interesante analizar si las variantes estudiadas pueden desencadenar este mecanismo. 
Otra posibilidad a analizar es la inducción de citotoxicidad sobre células endoteliales; dado el rol fisiológico de la apoA-I y las HDL en la regulación del binding de LDL oxidada, y en la inhibición de secreción endotelial de moléculas de adhesión para neutrófilos y macrófagos ${ }^{16}$, el estudio de la expresión de factores de adhesión intercelulares ó vasculares (ICAM ó VCAM) como marcadores de activación del endotelio podría ofrecer evidencia concreta. Si bien los intentos de obtención de cultivos primarios de Células endoteliales de cordón umbilical (HUVEC) no fueron exitosos, creemos que el establecimiento de este cultivo primario u otra línea de células endoteliales ayudará en el futuro cercano a establecer la importancia de la participación de ésta u otras variantes en la disfunción endotelial.

\section{E. LAS LECCIONES APRENDIDAS DE LA UNIÓN DE LIGANDOS}

\section{SDS}

Cómo se explicó en la introducción, la apoA-I humana está asociada con funciones clave en la prevención de la aterosclerosis. A fin de cumplir esas funciones, se plantea que su eficacia está dada por la capacidad de disociarse de las HDL e interaccionar con el transportador ABCA1 presente en los macrófagos ${ }^{91}$ para solubilizar el exceso de colesterol celular, es decir, que la apoA-I se encuentra por un tiempo libre en la íntima y está expuesta al entorno que la rodea. Por tal motivo, esta proteína es vulnerable a ser modificada por procesos del ambiente, como ser metilaciones, oxidaciones, clorinaciones, etc que pudieran ser como consecuencia de los eventos proinflamatorios que puedan dispararse localmente. Además de ello, las células responden a estos cambios modificando la composición lipídica en la monocapa externa de la membrana plasmática; por un lado pueden exponer mayor cantidad de fosfatidilserina, por otro pueden acumular glicoesfingolípidos sialidados ${ }^{92}$, otorgando mayor carga negativa a la monocapa externa.

Con el fin de considerar esta hipótesis, registramos primero la tendencia a la agregación de las variantes de apoA-I en presencia del detergente SDS, el cual fue usado como modelo in vitro de fosfolípido negativo, por contener una larga región hidrofóbica (cadena ácilica) y un grupo polar $\left(\mathrm{SO}_{4}{ }^{\overline{ }}\right)$ altamente cargado. La incubación se realizó con concentraciones de SDS por debajo de la CMC $(0,2 \mathrm{mM})$ en el buffer de reacción usado. A través de esto confirmamos una mayor tendencia de las variantes a formar 
agregados amiloides, tanto a pH 5,0 como 7,4. Este efecto podría ocurrir dada la participación del grupo de cabeza de este anfifilo en la unión electrostática con cargas positivas de la proteína, lo que concuerda con la pérdida de unión de ThT observada en presencia de altas concentraciones de ClNa (Figura 6A). Sin embargo, la variante Arg173Pro, a pesar de contener una carga positiva menos en su estructura (sustitución de una Arg por una Pro), fue más eficiente para formar complejos pro-amiloides a ambos pHs ensayados. Por lo tanto, es probable que, como fue descripto para la agregación de otras proteínas como sinucleína ${ }^{93}$ y péptidos ${ }^{94}$, las cadenas de alquilo de SDS puedan estimular la agregación, tal vez por la asociación con regiones no polares de las hélices anfipáticas, obligando a las interacciones intermoleculares. Se ha demostrado previamente que el microambiente lipídico podría inducir un cambio conformacional de la apoA-I o péptidos correspondientes a los dominios terminales ${ }^{44,45}$. La presencia de lípidos cargados negativamente en la membrana plasmática es una característica común asociada a la aterosclerosis u otros eventos inflamatorios crónicos locales que inducen apoptosis. Si éste fuera el caso, las proteínas podrían estar expuestas a la acidificación local en el fluido intersticial ${ }^{95}$, que a su vez podría provocar cambios conformacionales de la apoA-I, conduciendo a un plegamiento anómalo potencialmente patológico.

\section{GLUCOSAMINOGLUCANOS}

Los glicosaminoglicanos (GAGs) están formados por largas cadenas de dímeros constituidos por un aminoazúcar y un ácido urónico que están sulfatados y se unen a proteínas, formando proteoglicanos. Los GAGs forman parte de la matriz extracelular de todos los órganos y tienen múltiples funciones. En los vasos sanguíneos constituyen el glicocáliz endotelial y la matriz extracelular del endotelio y subendotelio. El glicocáliz es la primera barrera entre las células endoteliales y el torrente sanguíneo, con sus fuerzas de tensión, moléculas de adhesión, células circulantes y sistema de coagulación. En la matriz extracelular los GAGs (sobre todo heparán sulfato) regulan la acción de quimiocinas, citocinas, factores de crecimiento y la migración celular, así como la filtración de moléculas a través del endotelio ${ }^{46}$.

En los últimos años, estas moléculas fueron implicadas en el desarrollo de muchísimas patologías, entre ellas amiloidosis, aterosclerosis y enfermedad de Alzheimer. Particularmente su participación en amiloidosis está dada por inducir la agregación y formación de fibrillas, estabilizando así el proceso de nucleación ${ }^{19,47}$. En 
aterosclerosis, hay evidencia suficiente que sugiere un papel de los proteoglucanos en la génesis del proceso ateromatoso, alterando su conformación en eventos de injuria endotelial; por ejemplo cadenas de GAGs más elongadas, y el aumento de las cadenas de condroitín sulfato del biglicano inducen aumentada afinidad de las LDL a la pared vascular $^{96}$. Por otra parte el dermatán sulfato tendría un rol ateroprotector, tal es así que se plantea su potencial aplicación en el tratamiento y diagnóstico de enfermedades vasculares ${ }^{97}$. Fue descrito además un papel clave de los mismos al ofrecer una estructura de ensamblaje de fibrillas al péptido $\beta$ - amiloide implicado en la enfermedad de Alzheimer $^{76}$.

Un GAG que ha sido ensayado extensamente es la heparina. Si bien esta macromolécula in vivo es solo liberada por los mastocitos, su similitud química con heparán sulfato y su fácil acceso comercial permite su utilización como modelo para diversos estudios de interacción con proteínas. ${ }^{46}$ En condiciones fisiológicas, la apo Wt no presenta motivos típicos de unión a heparina ${ }^{98}$ pero resultados obtenidos previamente en el laboratorio ${ }^{41,43}$ sugieren una interacción de carácter electrostático entre la heparina y la proteína en medio ácido ( $\mathrm{pH}$ por debajo de 6), sugiriendo así un sitio probable de unión a heparina generad0 tras la protonación de las His 155 y 162 en la $\alpha$-hélice $6^{41}$ a este $\mathrm{pH}$.

En este trabajo, nos planteamos estudiar la interacción de la variante Arg173Pro con heparina. Encontramos que la fluorescencia asociada a ThT fue relativamente disminuida en la unión a heparina con respecto a la proteína $\mathrm{Wt}$ a $\mathrm{pH} 5,0$, un hecho que podría explicarse por una menor eficiencia para unirse a este GAG (figura 5.13). Pero especialmente interesante es el hecho de que, en cambio, la mutación induce una formación significativa de complejos a pH 7,4 (Figura 5.14 y 5.15 B), los cuales fueron caracterizados por AFM. (Figura 5.15A)

Con el fin de encontrar una posible explicación para este comportamiento, construimos un modelo de secuencia de la apoA-I que implica las hélices 6 y 7 (Figura $6.2 \mathrm{~A})$. 

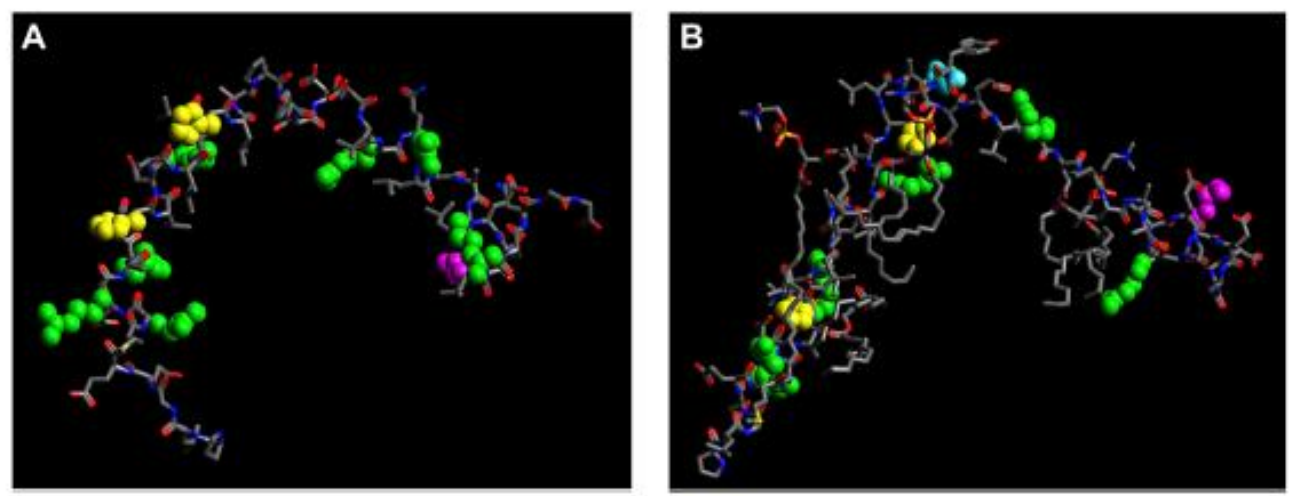

Figura 6.2: Modelo del péptido de Apo A-I probablemente involucrado en el sitio de unión de heparina. A) El modelo fue construido usando el software online www.expasy.org La secuencia cargada involucra los residuos 143-186 en la forma Wt (PLGEEMRIDRARAHVIDALRTHLAPYSDELRQRLLARLEALKENGG). La representación de esferas y palos fue obtenida con el software de Avogadro. Los residuos cargados positivamente se representan así: Arg en verde, His en amarillo y Lys en rosa. B) Misma representación para la variante Arg173 Pro (PLGEEMRIRARAHVIDALRTHLAPYSIELRQQPLAARLEALKENGG). El residuo de prolina involucrado en la mutación se muestra en color celeste.

Arg173Pro se encuentra aproximadamente en el medio de la hélice 7 (que comprende los residuos 165-186) y el modelo helicoidal de rueda predice que este residuo se enfrenta a la cara hidrofóbica de la hélice anfipática. Gursky y colaboradores propusieron $^{39}$ que la sustitución por Pro (en azul claro en la figura 6.2B) ubica un grupo polar en la parte inferior del cluster hidrofóbico y altera la conformación nativa alrededor de esta región y -como consecuencia- una alteración significativa de las interacciones sutiles con las hélices vecinas que ayudan a estabilizar la molécula entera. Mediante el uso de un software predictor de estructura secundaria SOPMA (www.expasy.org) se sugiere que la introducción de la Pro generaría en esta región un segmento de desorganización "ramdom coil" de 4 aminoácidos interrumpiendo la hélice alfa. Si esta mutación puntual afecta la unión a heparina, podríamos sugerir que la hélice 7, en la que se produce la mutación, quizás esté implicada en el motivo de unión que involucra a la hélice 6 en condiciones ácidas. La pérdida de la carga positiva debido a la mutación, más el efecto de la interrupción del residuo Pro, parcialmente podrían desorganizar la disposición espacial que se crea bajo un $\mathrm{pH}$ bajo, lo que provoca la disminución de la unión a ThT observado para el complejo (Figura 5.13).

Por otra parte, resulta evidente en esta variante la formación de un complejo proteína-GAG a pH 7,4 (Figura 5.14 y 5.15 B). Podemos especular que la interrupción de la hélice 7 permite la exposición de residuos crípticos que podrían potencialmente interactuar con los GAGs, constituyendo un segundo motivo de unión. Estas hélices 
contienen varios residuos positivos que podrían participar en esta interacción: 3 residuos Arg están alineados en la hélice $6^{43} \mathrm{y}$ - además la hélice 7 contiene 3 residuos positivos también (Arg 171, Arg 177 y Lys 182: Figura 6.2).

Con esto, creemos que los hallazgos presentados aquí ofrecen nuevas pistas que ayudan a comprender las vías patológicas, lo que sugiere la unión específica de los mutantes a GAGs en un contexto fisiológico. En apoyo a esta línea de evidencia, se observó acumulación de heparán sulfato en depósitos amiloides de $\operatorname{TTR}^{99}$ en el corazón de un paciente diagnosticado con cardiomiopatía amiloide. Se sabe que los GAGs desempeñan funciones complejas en eventos celulares tan diversos como la proliferación o envejecimiento ${ }^{48,49}$. Además, se demostró recientemente que el dermatan sulfato de bajo peso molecular modula la proliferación celular endotelial y la migración ${ }^{50}$. Vale la pena señalar que evidencia científica apoya que los GAG podrían participar en la amiloidogénesis in vivo, tal vez incluso en un papel protector, por la conversión de los oligómeros solubles proteotóxicos en fibrillas de amiloide menos tóxicas y relacionados a los agregados de hoja $\beta$ entrecruzada ${ }^{51}$. En nuestro conocimiento, todavía no se sabe la estructura de variantes de apoA-I que podría ser más tóxico que induce daño en los órganos. Más investigación debe llevarse a cabo con el fin de obtener una visión más profunda de la interrelación de variantes de apoA-I y ligandos en circulación.

\section{F. POLIMEROS}

Aunque la composición de la matriz extracelular es altamente compleja, los GAGs tienden a adoptar conformaciones muy extendidas que ocupan un volumen enorme con respecto a su masa formando geles hidratados incluso a concentraciones muy bajas. Las cadenas de GAGs llenan la mayor parte del espacio extracelular. Debido a que hay grupos sulfato o carboxilo en la mayoría de los azúcares componentes, los GAGs son moléculas altamente cargadas negativamente que juegan un papel clave en mantener las cantidades de agua, confiriendo alta viscosidad a la solución; además, podrían participar en interacciones débiles entre otras moléculas ${ }^{100}$. El resto sulfato de los GAGs es crítico para el aumento de la formación de fibrillas A $\beta$ eta ${ }^{101}$. Además, los grupos sulfato han sido indicados previamente como el principal residuo responsable en las interacciones de proteínas pro-amiloidogénicas con GAGs en la matriz extracelular ${ }^{102}$, y por lo tanto debe ser un candidato para probar. 
En base a ello, la formación de polímeros sintéticos se planteó como un acercamiento para el estudio de la interacción de las proteínas con grupos constituyentes de una matriz. En este caso se eligió 4-Estirén sulfonato y HEMA, los cuales exponen en su superficie un grupo sulfato y otro hidroxilo, semejando los grupos expuestos en los GAGs.

El hallazgo de que Arg173Pro muestra una unión más fuerte a la matriz rica en sulfato apoya que, al menos para esta variante estudiada, el mecanismo patológico podría ser una mayor retención y / o agregación en la matriz extracelular que podría además disminuir la cantidad fisiológica de proteína disponible para participar en el catabolismo lipídico. Curiosamente, la interacción no es sólo la suma de las cargas negativas, ya que los monómeros no producen un efecto drástico sobre la conformación de proteínas o la unión a otras moléculas como la heparina. En cambio, la matriz parece funcionar como una "plataforma" basal en la que las cargas, la viscosidad o probablemente los bolsillos estructurales ayudan a la fuerza de la interacción y la retención de proteínas en el microambiente.

Comprender la interacción de las proteínas amiloidogénicas con GAGs es definitivamente un objetivo en el diseño de compuestos anti-amiloides como nuevos agentes terapéuticos para el tratamiento de dichas enfermedades. Basándose en estudios previos, una nueva clase de compuestos está diseñada para interferir con las interacciones entre proteínas amiloidogénicas y GAGs y por lo tanto podrían aplicarse para inhibir la polimerización y el depósito de fibrillas en tejidos ${ }^{52,103,104,105}$. Estos estudios implican compuestos con grupos sulfato con diferentes eficiencias ya sea in vivo o in vitro. Aunque estos estudios todavía no están en una "fase" clínica, es una estrategia prometedora para inhibir la agregación patológica de proteínas amiloides. (Figura 6.3)

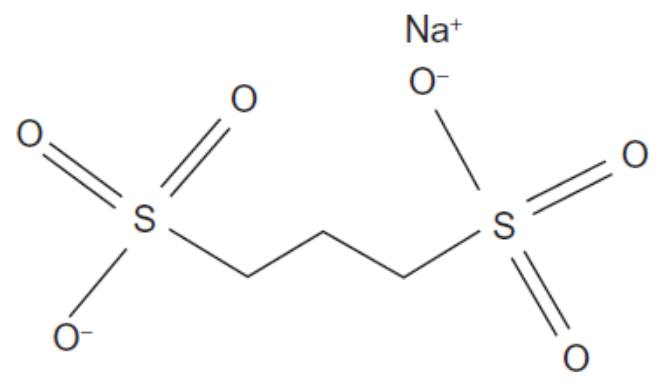

$\mathrm{Na}^{+}$

Figura 6.3: Estructura química de la sal Ácido 1,3-propanosullónico disódico (EPR0DISAT0) ${ }^{52}$ 
En esta dirección, está claro que un control fino de cargas o polaridad es una pista para comprender y mediar en la interacción de mutantes de apoA-I con la matriz extracelular. Los polímeros que utilizamos aquí son fáciles de construir y caracterizar, reproducibles y su "transparencia" permite ser utilizados como herramientas biofísicas, por ejemplo la fluorescencia para analizar la unión y conformación de proteínas tales como apoA-I y los mutantes patológicos.

Muchos estudios sugieren que los GAGs están implicados en varios eventos patológicos, desde la inflamación a la neurodegeneración. La riqueza de este modelo se basa en la posibilidad de controlar de cerca la composición de los grupos que podrían determinar el delicado equilibrio de apoA-I y componentes de la matriz extracelular. 


\section{CONCLUSIONES GENERALES}

La amilodosis debido a apoA-I es un área de vacancia en Argentina. En este trabajo ahondamos en resolver la hipótesis de que diversos mecanismos pueden participar de la patogenia debida a mutantes de esta proteína. El concepto de interrelación de una proteína con macromoléculas del microambiente o reacciones celulares debe ser considerado a fin de interpretar e integrar los eventos participantes.

Considero que la riqueza de este trabajo consiste en que no sólo se sugieren motivos macromoleculares que participan en la patogenicidad de la proteína, sino que cada uno de estos eventos abre per se un gran campo de estudio, factible de ser explorado. Así, los estudios presentados acá sugieren:

a) Una tendencia intrínseca de la proteina a agregarse en forma de compuestos pro-amiloidogénicos. Esta observación sin embargo sugiere que no sería suficiente para desencadenar la patología, ya que se precisaría condiciones alejadas de las fisiológicas para obtener conformaciones fibrilares características a las encontradas en las lesiones de pacientes.

b) Una característica de los agregados amiloides debidos a apoA-I es la presencia de fragmentos $N$-terminales de la proteína en lesiones de pacientes. El porqué esta evidencia no es conocido, aunque nuestros datos indican un aumento en la sensibilidad de la variante estudiada a eventos de proteólisis. La ocurrencia de modificaciones pos traduccionales en eventos crónicos como proteólisis, oxidaciones, clorinaciones etc es altamente compleja y será un desafío el encontrar la especificidad de este evento.

c) La interacción con ligandos del microambiente, entre los cuales lípidos negativos o en especial glicosaminoglicanos de la matriz extracelular son candidatos. Es sin duda una de las conclusiones más importantes de este estudio. Fenómenos celulares crónicos como inflamación y aterosclerosis se asocian a cambios activos en entornos vasculares, en los que no sólo cambia la composición de la membrana sino que los proteoglicanos sufren alteración en la expresión de las cadenas de los GAGs que contribuyen a establecer patrones pro- o anti aterogénico. La interacción con grupos del micro ambiente no sólo puede aumentar la retención de la proteína sino inducir cambios conformacionales que alteren su función. Asi, el hallazgo de una interacción específica del mutante estudiado Arg173Pro con modelos de GAGs y con 
preferencia por grupos sulfato abre un campo inmenso a fin de poder interpretar, para esta u otras proteínas amiloidogénicas, la probable razón aún desconocida del por qué el depósito local en distintos órganos de cada mutante.

d) Finalmente, el hallazgo que la variante Arg173Pro aún en su conformación nativa es capaz de inducir la liberación de señales pro-inflamatorias soporta, como fue observado con otras variantes de apoA-I, que puede existir una interrelación específica entre el efecto de los mutantes sobre el microambiente y, por oposición, un procesamiento del microambiente induciendo la formación de especies proteicas tóxicas. Estos campos serán un gran desafío a fin de conocer las causas de la amiloidosis asociada a apoA-I. 


\section{BIBLIOGRAFIA}

1. Law SW, Brewer HB. Nucleotide sequence and the encoded amino acids of human apolipoprotein A-I mRNA Biochemistry : 1984;81(January):66-70.

2. Scanu AM, Byrne RE, Edelstein C. Proteolytic events affecting plasma apolipoproteins at the co- and post-translational levels and after maturation. $J$ Lipid Res. 1984;25(13):1593-1602. http://www.ncbi.nlm.nih.gov/pubmed/6442340. Accessed March 14, 2017.

3. Segrest J. et al. Amphipathic Helix Motif : Classes and Properties. 1990;117:103-117.

4. Obici L, Franceschini G, Calabresi L, et al. Structure , function and amyloidogenic propensity of apolipoprotein A-I. 2006;13(December):191-205. doi:10.1080/13506120600960288.

5. $\quad$ Segrest JP, Jones MK, De Loof H, Brouillette CG, Venkatachalapathi YV, Anantharamaiah GM. The amphipathic helix in the exchangeable apolipoproteins: A review of secondary structure and function. J Lipid Res. 1992;33(2).

6. Oda MN. Biochimica et Biophysica Acta Lipid-free apoA-I structure - Origins of model diversity. BBA - Mol Cell Biol Lipids. 2017;1862(2):221-233. doi:10.1016/j.bbalip.2016.11.010.

7. Gursky, Olga \& Atkinson D. Thermal unfolding of human high-density apolipoprotein A-i : Implications for a lipid-free molten globular state. 1996;93(April):2991-2995.

8. Freire E. Thermodynamics of partly folded intermediates in proteins. Annu Rev Biophys Biomol Struct. 1995;24:141-165. doi:10.1146/annurev.bb.24.060195.001041.

9. Davidson WS, Thompson TB. The structure of apolipoprotein A-I in high density lipoproteins. J Biol Chem. 2007;282(31):22249-22253. doi:10.1074/jbc.R700014200.

10. Tricerri MA, Behling Agree AK, Sanchez SA, Bronski J, Jonas A. Arrangement of apolipoprotein A-I in reconstituted high-density lipoprotein disks: an alternative model based on fluorescence resonance energy transfer experiments. Biochemistry. 2001;40(16):5065-5074. doi:bi002815q [pii].

11. Silva R a GD, Huang R, Morris J, et al. Structure of apolipoprotein A-I in spherical high density lipoproteins of different sizes. Proc Natl Acad Sci U S A. 2008;105(34):1217612181. doi:10.1073/pnas.0803626105.

12. Mei X, Atkinson D. Crystal Structure of C-Terminal Truncated Apolipoprotein A-I Reveals the Assembly of High Density Lipoprotein (HDL ) by. Vol 286.; 2011. doi:10.1074/jbc.M111.260422.

13. Curtiss LK, Valenta DT, Hime NJ, Rye K. What Is So Special About Apolipoprotein AI in Reverse Cholesterol Transport ? 2005. doi:10.1161/01.ATV.0000194291.94269.5a.

14. Jolley CD, Woollett L a, Turley SD, Dietschy JM. Centripetal cholesterol flux to the liver is dictated by events in the peripheral organs and not by the plasma high density lipoprotein or apolipoprotein A-I concentration. J Lipid Res. 1998;39(11):2143-2149. http://www.ncbi.nlm.nih.gov/pubmed/9799800.

15. Drew BG, Fidge NH, Gallon-Beaumier G, Kemp BE, Kingwell B a. High-density lipoprotein and apolipoprotein $\mathrm{AI}$ increase endothelial NO synthase activity by protein association and multisite phosphorylation. Proc Natl Acad Sci U S A. 2004;101(18):6999-7004. doi:10.1073/pnas.0306266101. 
16. Dimayuga P, Zhu J, Oguchi S, et al. Reconstituted HDL containing human apolipoprotein A-1 reduces VCAM-1 expression and neointima formation following periadventitial cuff-induced carotid injury in apoE null mice. Biochem Biophys Res Commun. 1999;264(2):465-468. doi:10.1006/bbrc.1999.1278.

17. Suc I, Escargueil-Blanc I, Troly M, Salvayre R, Nègre-Salvayre A. HDL and ApoA prevent cell death of endothelial cells induced by oxidized LDL. Arterioscler Thromb Vasc Biol. 1997. doi:10.1161/01.ATV.17.10.2158.

18. Hassan HH, Denis M, Krimbou L, Marcil M, Genest J. Cellular cholesterol homeostasis in vascular endothelial cells. Can J Cardiol. 2006;22 Suppl B(Suppl B):35B-40B. http://www.ncbi.nlm.nih.gov/pubmed/16498511\%5Cnhttp://www.pubmedcentral.nih.go v/articlerender.fcgi?artid=PMC2780830.

19. Merlini G, Bellotti V. Molecular mechanisms of amyloidosis. N Engl J Med. 2003;349(6):583-596. doi:10.1056/NEJMra023144.

20. Chen W, Dilsizian V. Molecular imaging of amyloidosis: will the heart be the next target after the brain? Curr Cardiol Rep. 2012;14(2):226-233. doi:10.1007/s11886-011-0239-5.

21. Buxbaum JN, Tagoe CE. The genetics of the amyloidoses *. 2000:543-569.

22. Dember LM. Amyloidosis-associated kidney disease. J Am Soc Nephrol. 2006;17(12):3458-3471. doi:10.1681/ASN.2006050460.

23. Saraiva MJM. Transthyretin amyloidosis: A tale of weak interactions. FEBS Lett. 2001;498(2-3):201-203. doi:10.1016/S0014-5793(01)02480-2.

24. Eriksson M, Schönland S, Yumlu S, et al. Hereditary apolipoprotein AI-associated amyloidosis in surgical pathology specimens: identification of three novel mutations in the APOA1 gene. J Mol Diagn. 2009;11(3):257-262. doi:10.2353/jmoldx.2009.080161.

25. Gregorini G, Izzi C, Obici L, et al. Renal apolipoprotein A-I amyloidosis: a rare and usually ignored cause of hereditary tubulointerstitial nephritis. J Am Soc Nephrol. 2005;16(12):3680-3686. doi:10.1681/ASN.2005040382.

26. Vigushin DM, Booth SE, Booth DR, et al. Familial nephropathic systemic amyloidosis caused by apolipoprotein Al variant Arg26. QJM. 1994.

doi:10.1093/oxfordjournals.qjmed.a068909.

27. Booth DR, Tan SY, Booth SE, et al. Hereditary hepatic and systemic amyloidosis caused by a new deletion/insertion mutation in the apolipoprotein al gene. J Clin Invest. 1996. doi:10.1172/JCI118725.

28. Obici L, Bellotti V, Mangione P, et al. The new apolipoprotein A-I variant leu(174) -\&gt; Ser causes hereditary cardiac amyloidosis, and the amyloid fibrils are constituted by the 93-residue N-terminal polypeptide. Am J Pathol. 1999;155(3):695-702. doi:10.1016/S0002-9440(10)65167-X.

29. Hamidi Asl K, Liepnieks JJ, Nakamura M, Parker F, Benson MD. A novel apolipoprotein A-1 variant, Arg173Pro, associated with cardiac and cutaneous amyloidosis. Biochem Biophys Res Commun. 1999;257(2):584-588. doi:10.1006/bbrc.1999.0518.

30. Lachmann HJ, Booth DR, Booth SE, et al. Misdiagnosis of hereditary amyloidosis as AL (primary) amyloidosis. $N$ Engl J Med. 2002. doi:10.1056/NEJMoa013354 [doi] 346/23/1786 [pii]. 
31. Amarzguioui M, Mucchiano G, Haggqvist B, et al. Extensive intimal apolipoprotein A1derived amyloid deposits in a patient with an apolipoprotein A1 mutation. Biochem Biophys Res Commun. 1998. doi:10.1006/bbrc.1997.8005.

32. Van Allen MW, Frohlich JA, Davis JR. Inherited predisposition to generalized amyloidosis. Clinical and pathological study of a family with neuropathy, nephropathy, and peptic ulcer. Neurology. 1969;19(1):10-25.

33. Booth DR, Tan SY, Booth SE, et al. A new apolipoprotein Al variant, Trp50Arg, causes hereditary amyloidosis. QJM. 1995;88(10):695-702.

34. Soutar AK, Hawkins PN, Vigushin DM, et al. Apolipoprotein AI mutation Arg-60 causes autosomal dominant amyloidosis. Proc Natl Acad Sci U S A. 1992;89(16):73897393.

35. Sorci-Thomas MG, Thomas MJ. The effects of altered apolipoprotein A-I structure on plasma HDL concentration. Trends Cardiovasc Med. 2002;12(3):121-128.

36. Schaefer EJ, Anthanont P, Asztalos BF. High-density lipoprotein metabolism, composition, function, and deficiency. Curr Opin Lipidol. 2014;25(3):194-199. doi:10.1097/MOL.0000000000000074.

37. Mucchiano GI, Haggqvist B, Sletten K, Westermark P. Apolipoprotein A-1-derived amyloid in atherosclerotic plaques of the human aorta. J Pathol. 2001;193(2):270-275. doi:10.1002/1096-9896(2000)9999:9999<::AID-PATH753>3.0.CO;2-S.

38. Raimondi S, Guglielmi F, Giorgetti S, et al. Effects of the known pathogenic mutations on the aggregation pathway of the amyloidogenic peptide of apolipoprotein A-I. $J \mathrm{Mol}$ Biol. 2011;407(3):465-476. doi:10.1016/j.jmb.2011.01.044.

39. Gursky O, Mei X, Atkinson D. The Crystal Structure of the C-Terminal Truncated Apolipoprotein A-I Sheds New Light on Amyloid Formation by the N-Terminal Fragment. 2012;(Table 1).

40. Nichols WC, Gregg RE, Brewer HBJ, Benson MD. A mutation in apolipoprotein A-I in the Iowa type of familial amyloidotic polyneuropathy. Genomics. 1990;8(2):318-323.

41. Ramella N a, Schinella GR, Ferreira ST, et al. Human apolipoprotein A-I natural variants: molecular mechanisms underlying amyloidogenic propensity. PLoS One. 2012;7(8):e43755. doi:10.1371/journal.pone.0043755.

42. Posadas-martínez ML, Aguirre A, Blomberg M, Greloni G. Amiloidosis , una enfermedad huérfana : creación de un registro institucional de amiloidosis. 2013;(January).

43. Ramella N a, Rimoldi OJ, Prieto ED, et al. Human apolipoprotein A-I-derived amyloid: its association with atherosclerosis. PLoS One. 2011;6(7):e22532. doi:10.1371/journal.pone.0022532.

44. Mendoza-Espinosa P, Montalvan-Sorrosa D, Garcia-Gonzalez V, Moreno A, Castillo R, Mas-Oliva J. Microenvironmentally controlled secondary structure motifs of apolipoprotein A-I derived peptides. Mol Cell Biochem. 2014;393(1-2):99-109. doi:10.1007/s11010-014-2050-2.

45. Arnulphi C, Sanchez SA, Tricerri MA, Gratton E, Jonas A. Interaction of human apolipoprotein A-I with model membranes exhibiting lipid domains. Biophys $J$. 2005;89(1):285-295. doi:10.1529/biophysj.104.047480. 
46. Frati-munari AC. Glicosaminoglicanos en las enfermedades vasculares. 2012;40.

47. Cohlberg JA, Li J, Uversky VN, Fink AL. Heparin and Other Glycosaminoglycans Stimulate the Formation of Amyloid Fibrils from R -Synuclein in Vitro †. 2002:15021511.

48. Kinsella MG, Bressler SL, Wight TN. The regulated synthesis of versican, decorin, and biglycan: extracellular matrix proteoglycans that influence cellular phenotype. Crit Rev Eukaryot Gene Expr. 2004;14(3):203-234.

49. Shirk RA, Parthasarathy N, San Antonio JD, Church FC, Wagner WD. Altered dermatan sulfate structure and reduced heparin cofactor II-stimulating activity of biglycan and decorin from human atherosclerotic plaque. J Biol Chem. 2000;275(24):18085-18092. doi:10.1074/jbc.M001659200.

50. Rasente RY, Egitto P, Calabrese GC. Low molecular mass dermatan sulfate modulates endothelial cells proliferation and migration. Carbohydr Res. 2012;356:233-237. doi:10.1016/j.carres.2012.03.036.

51. Iannuzzi C, Irace G, Sirangelo I. The effect of glycosaminoglycans (GAGs) on amyloid aggregation and toxicity. Molecules. 2015;20(2):2510-2528. doi:10.3390/molecules20022510.

52. Rumjon A, Coats T, Javaid MM. Review of eprodisate for the treatment of renal disease in AA amyloidosis. 2012:37-43.

53. Gomaraschi M, Baldassarre D, Amato M, et al. Normal vascular function despite low levels of high-density lipoprotein cholesterol in carriers of the apolipoprotein AI(Milano) mutant. Circulation. 2007;116(19):2165-2172. doi:10.1161/CIRCULATIONAHA.107.705657.

54. Favari E, Gomaraschi M, Zanotti I, et al. A unique protease-sensitive high density lipoprotein particle containing the apolipoprotein A-I(Milano) dimer effectively promotes ATP-binding Cassette A1-mediated cell cholesterol efflux. J Biol Chem. 2007;282(8):5125-5132. doi:10.1074/jbc.M609336200.

55. Shah PK, Nilsson J, Kaul S, et al. Effects of Recombinant Apolipoprotein A-I Milano on Aortic Atherosclerosis in Apolipoprotein E - Deficient Mice. 1998.

56. $\quad$ Esper RJ . Vilarino J. Progresos En Aterotrombosis. Médicas de.; 2011.

57. Navab M, Anantharamaiah GM, Fogelman AM. The role of high-density lipoprotein in inflammation. Trends Cardiovasc Med. 2005;15(4):158-161. doi:10.1016/j.tcm.2005.05.008.

58. Russell. S\&. Molecular Cloning and Laboratory Manual: CSHL (Cold Sprimg Harbor Laboratory Press, New York).; 2001.

59. Lederberg EM, Cohen SN. Transformation of Salmonella typhimurium by plasmid deoxyribonucleic acid. J Bacteriol. 1974;119(3):1072-1074.

60. Ryan RO, Forte TM, Oda MN. Optimized bacterial expression of human apolipoprotein A-I. Protein Expr Purif. 2003;27(1):98-103.

61. Bradford MM. A rapid and sensitive method for the quantitation of microgram quantities of protein utilizing the principle of protein-dye binding. Anal Biochem. 1976;72(1-

2):248-254. doi:10.1016/0003-2697(76)90527-3. 
62. Laemmli UK. Cleavage of Structural Proteins during the Assembly of the Head of Bacteriophage T4. Nature. 1970;227(5259):680-685.

http://dx.doi.org/10.1038/227680a0.

63. Soto C, Guillermo J, Plata C, et al. Evaluación de Procedimientos de Tinción para el Análisis de Proteínas por Electroforesis ( SDS-PAGE ). Invurnus. 2013;1(1):19-26.

64. Lakowicz JR. Principles of Fluorescence Spectroscopy. Springer New York; 2006.

65. Gomori G. Preparation of Buffers for Use in Enzyme Studies ( by G . Gomori ). Enzyme. 2004:2-10. doi:10.1016/0076-6879(55)01020-3.

66. Córsico B, Falomir Lockhart LJ, Franchini GR, Scaglia N. Análisis Estructural Y Funcional de Macromoléculas.; 2013.

67. Martins SM, Chapeaurouge A, Ferreira ST. Folding intermediates of the prion protein stabilized by hydrostatic pressure and low temperature. $J$ Biol Chem.

2003;278(50):50449-50455. doi:10.1074/jbc.M307354200.

68. Botelho MG, Gralle M, Oliveira CLP, Torriani I, Ferreira ST. Folding and stability of the extracellular domain of the human amyloid precursor protein. $J$ Biol Chem. 2003;278(36):34259-34267. doi:10.1074/jbc.M303189200.

69. Chapeaurouge A, Johansson JS, Ferreira ST. Folding intermediates of a model threehelix bundle protein. Pressure and cold denaturation studies. $J$ Biol Chem. 2001;276(18):14861-14866. doi:10.1074/jbc.M009622200.

70. Gerald D. Fasman. Circular Dichroism and the Conformacional Analysis of Biomolecules. (Fasman GD, ed.); 1996. doi:10.1007/978-1-4757-2508-7.

71. Creighton TE. Protein Structure: A Practical Approach. IRL Press at Oxford University Press; 1997. https:/global.oup.com/academic/product/protein-structure9780199636181\#.WMnMMCOAuJA.mendeley\&title=Protein Structure. Accessed March 15, 2017.

72. Shi Y, Fan D-J, Li S-X, Zhang H-J, Perrett S, Zhou J-M. Identification of a potential hydrophobic peptide binding site in the C-terminal arm of trigger factor. Protein Sci. 2007;16(6):1165-1175. doi:10.1110/ps.062623707.

73. LeVine H 3rd. Quantification of beta-sheet amyloid fibril structures with thioflavin T. Methods Enzymol. 1999;309:274-284.

74. Prieto ED, Ramella N, Cuellar LA, Tricerri MA, Garda HA. Characterization of a human apolipoprotein a-I construct expressed in a bacterial system. Protein J. 2012;31(8):681688. doi:10.1007/s10930-012-9448-z.

75. Kisilevsky R. Review : Amyloidogenesis - Unquestioned Answers and Unanswered Questions. 2000;108:99-108. doi:10.1006/jsbi.2000.4222.

76. McLaurin J, Yang D, Yip CM, Fraser PE. Review: modulating factors in amyloid-beta fibril formation. J Struct Biol. 2000;130(2-3):259-270. doi:10.1006/jsbi.2000.4289.

77. Nan Yao - Zhong Lin Wang. Handbook of Microscopy for Nanotechnology. (Yao, Nan, Wang ZL, ed.). Princeton University, Princeton, USA • Georgia Institute of Technology, Atlanta, USA; 2005. doi:10.1007/1-4020-8006-9.

78. López EA, Solares SD. El microscopio de fuerza atómica: métodos y aplicaciones. Rev la Univ del Val Guatemala. 2014:14-28. 
79. Geckil H, Xu F, Zhang X, Moon S, Demirci U. Engineering hydrogels as extracellular matrix mimics. Nanomedicine (Lond). 2010;5(3):469-484. doi:10.2217/nnm.10.12.

80. Chapeaurouge A, Johansson JS, Ferreira ST. Folding of a de novo designed native-like four-helix bundle protein. $J$ Biol Chem. 2002;277(19):16478-16483. doi:10.1074/jbc.M105232200.

81. Hawe A, Sutter M, Jiskoot W. Extrinsic fluorescent dyes as tools for protein characterization. Pharm Res. 2008;25(7):1487-1499. doi:10.1007/s11095-007-9516-9.

82. Pertinhez TA, Bouchard M, Smith RAG, Dobson CM, Smith LJ. Stimulation and inhibition of fibril formation by a peptide in the presence of different concentrations of SDS. FEBS Lett. 2002;529(2-3):193-197.

83. Kihara M, Chatani E, Sakai M, Hasegawa K, Naiki H, Goto Y. Seeding-dependent maturation of beta2-microglobulin amyloid fibrils at neutral $\mathrm{pH} . J$ Biol Chem. 2005;280(12):12012-12018. doi:10.1074/jbc.M411949200.

84. Westermark P, Mucchiano G, Marthin T, Johnson KH, Sletten K. Apolipoprotein A1derived amyloid in human aortic atherosclerotic plaques. Am J Pathol. 1995;147(5):1186-1192.

85. Souillac PO, Uversky VN, Millett IS, Khurana R, Doniach S, Fink AL. Effect of association state and conformational stability on the kinetics of immunoglobulin light chain amyloid fibril formation at physiological pH. J Biol Chem. 2002;277(15):1265712665. doi:10.1074/jbc.M109230200.

86. Booth DR, Sunde M, Bellotti V, et al. Instability, unfolding and aggregation of human lysozyme variants underlying amyloid fibrillogenesis. Nature. 1997;385(6619):787-793. doi: $10.1038 / 385787 \mathrm{a} 0$.

87. Hammarström P, Sekijima Y, White JT, et al. D18G transthyretin is monomeric, aggregation prone, and not detectable in plasma and cerebrospinal fluid: a prescription for central nervous system amyloidosis? Biochemistry. 2003;42(22):6656-6663. doi:10.1021/bi027319b.

88. Adachi E, Kosaka A, Tsuji K, et al. The extreme N-terminal region of human apolipoprotein A-I has a strong propensity to form amyloid fibrils. FEBS Lett. 2014;588(3):389-394. doi:10.1016/j.febslet.2013.11.031.

89. Das M, Mei X, Jayaraman S, Atkinson D, Gursky O. Amyloidogenic mutations in human apolipoprotein A-I are not necessarily destabilizing - a common mechanism of apolipoprotein A-I misfolding in familial amyloidosis and atherosclerosis. FEBS J. 2014;281(11):2525-2542. doi:10.1111/febs.12809.

90. Azevedo EPC, Guimarães-Costa AB, Torezani GS, et al. Amyloid fibrils trigger the release of neutrophil extracellular traps (NETs), causing fibril fragmentation by NETassociated elastase. J Biol Chem. 2012;287(44):37206-37218. doi:10.1074/jbc.M112.369942.

91. Curtiss LK, Valenta DT, Hime NJ, Rye K-A. What is so special about apolipoprotein AI in reverse cholesterol transport? Arterioscler Thromb Vasc Biol. 2006;26(1):12-19. doi:10.1161/01.ATV.0000194291.94269.5a.

92. Wettreich A, Sebollela A, Carvalho MA, Azevedo SP, Ferreira T, Coelho-sampaio T. Acidic pH Modulates the Interaction between Human Granulocyte- Macrophage Colonystimulating Factor and Glycosaminoglycans *. 1999;274(44):31468-31475. 
93. Ahmad MF, Ramakrishna T, Raman B, Rao CM. Fibrillogenic and non-fibrillogenic ensembles of SDS-bound human alpha-synuclein. J Mol Biol. 2006;364(5):1061-1072. doi:10.1016/j.jmb.2006.09.085.

94. Roman EA, Rosi P, Gonzalez Lebrero MC, et al. Gain of local structure in an amphipathic peptide does not require a specific tertiary framework. Proteins. 2010;78(13):2757-2768. doi:10.1002/prot.22789.

95. van der Goot FG, Gonzalez-Manas JM, Lakey JH, Pattus F. A "molten-globule" membrane-insertion intermediate of the pore-forming domain of colicin A. Nature. 1991;354(6352):408-410. doi:10.1038/354408a0.

96. Anggraeni VY, Emoto N, Yagi K, et al. Correlation of C4ST-1 and ChGn-2 expression with chondroitin sulfate chain elongation in atherosclerosis. Biochem Biophys Res Commun. 2011;406(1):36-41. doi:http://dx.doi.org/10.1016/j.bbrc.2011.01.096.

97. Rasente RY, Imperiale JC, Lázaro-Martínez JM, et al. Dermatan sulfate/chitosan polyelectrolyte complex with potential application in the treatment and diagnosis of vascular disease. Carbohydr Polym. 2016;144:362-370. doi:10.1016/j.carbpol.2016.02.046.

98. Harel A, Fainaru M, Rubinstein M, Tal N, Schwartz M. Fish apolipoprotein-A-I has heparin binding activity: implication for nerve regeneration. $J$ Neurochem. 1990;55(4):1237-1243.

99. Noborn F, O'Callaghan P, Hermansson E, et al. Heparan sulfate/heparin promotes transthyretin fibrillization through selective binding to a basic motif in the protein. Proc Natl Acad Sci U S A. 2011;108(14):5584-5589. doi:10.1073/pnas.1101194108.

100. Iannuzzi C, Irace G, Sirangelo I. The effect of glycosaminoglycans (GAGs) on amyloid aggregation and toxicity. Molecules. 2015;20(2):2510-2528.

doi:10.3390/molecules20022510.

101. Castillo GM, Lukito W, Wight TN, Snow AD. The sulfate moieties of glycosaminoglycans are critical for the enhancement of ??-amyloid protein fibril formation. J Neurochem. 1999;72(4):1681-1687. doi:10.1046/j.14714159.1999.721681.x.

102. Li J-P, Galvis MLE, Gong F, et al. In vivo fragmentation of heparan sulfate by heparanase overexpression renders mice resistant to amyloid protein A amyloidosis. Proc Natl Acad Sci U S A. 2005;102(18):6473-6477. doi:10.1073/pnas.0502287102.

103. Lucio Manenti PT\& AV. Eprodisate in amyloid A amyloidosis : a novel therapeutic approach ? Expert Opin Pharmacother. 2008:2175-2180.

104. Kisilevsky R, Lemieux LJ, Fraser PE, Kong X, Hultin PG, Szarek W a. Arresting amyloidosis in vivo using small-molecule anionic sulphonates or sulphates: implications for Alzheimer's disease. Nat Med. 1995;1:143-148. doi:10.1038/nm0295-143.

105. Gandhi NS, Mancera RL. Heparin/heparan sulphate-based drugs. Drug Discov Today. 2010;15(23-24):1058-1069. doi:10.1016/j.drudis.2010.10.009. 
